\title{
MACROECONOMIC AND FINANCIAL STABILITY \\ CHALLENGES FOR \\ ACCEDING AND \\ CANDIDATE COUNTRIES
}

by the International Relations Committee

Task Force on Enlargement 
EUROPEAN CENTRAL BANK

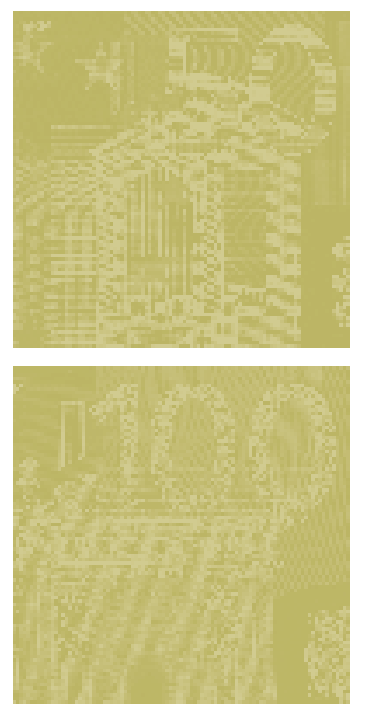

\title{
OCCASIONAL PAPER SERIES
} N0. 48 I JULY 2006

\author{
MACROECONOMIC AND \\ FINANCIAL STABILITY \\ CHALLENGES FOR \\ ACCEDING AND \\ CANDIDATE COUNTRIES
}

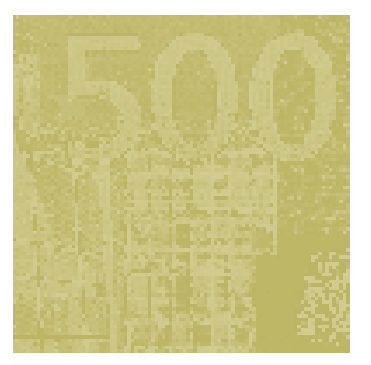

by the International Relations Committee

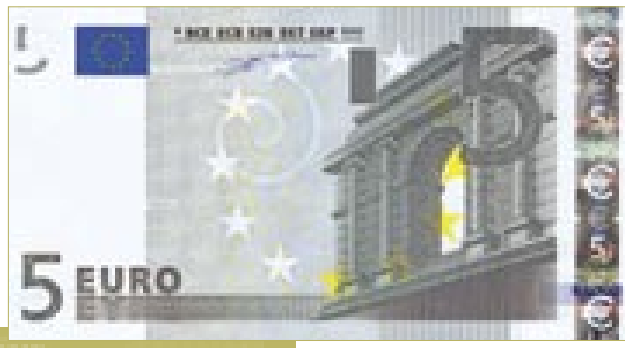

Task Force on Enlargement'

In 2006 all ECB

publications

will feature

a motif taken

from the

$€ 5$ banknote.

This paper can be downloaded without charge from http://www.ecb.int or from the Social Science Research Network electronic library at http://ssrn.com/abstract_id $=807425$. 


\section{(C) European Central Bank, 2006}

Address

Kaiserstrasse 29

60311 Frankfurt am Main

Germany

Postal address

Postfach 160319

60066 Frankfurt am Main

Germany

Telephone

+496913440

Website

http://www.ecb.int

Fax

+496913446000

Telex

411144 ecb d

All rights reserved. Any reproduction, publication or reprint in the form of a different publication, whether printed or produced electronically, in whole or in part, is permitted only with the explicit written authorisation of the ECB or the author(s).

The views expressed in this paper do not necessarily reflect those of the European Central Bank.

ISSN 1607-1484 (print)

ISSN 1725-6534 (online) 


\section{CONTENTS}

ABSTRACT

SUMMARY

I PREFACE

2 BULGARIA

2.1 Macroeconomic developments and vulnerabilities

2.2 The Bulgarian banking sector Structure and developments Risks and shock-absorbing capacities

2.3 Summary and conclusions

3 ROMANIA

3.1 Macroeconomic developments and vulnerabilities

3.2 The Romanian banking sector Structure and developments Risks and shock-absorbing capacities

3.3 Summary and conclusions

4 CROATIA

4.1 Macroeconomic developments and vulnerabilities

4.2 The Croatian banking sector $\quad 35$

Structure and developments $\quad 35$

Risks and shock-absorbing

capacities

4.3 Summary and conclusions

5 TURKEY

5.1 Macroeconomic developments and vulnerabilities

5.2 The Turkish banking sector Structure and developments Risks and shock-absorbing capacities

5.3 Summary and conclusions 8

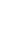
|

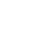

\section{SPECIAL FEATURES}

1 Financial markets and non-bank financial institutions

2 The role of foreign banks

3 The role of foreign currencies

4 The supervisory framework

\section{COUNTRY SHEETS}

REFERENCES

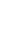

35




\section{ABSTRACT}

This paper - based on a report by a Task Force established by the International Relations Committee (IRC) of the European System of Central Banks (ESCB)-reviews macroeconomic and financial stability challenges for acceding (Bulgaria and Romania) and candidate countries (Croatia and Turkey). In an environment characterised by strong growth and capital inflows, the main macroeconomic challenges relate to the recent pick-up of inflation and the large and widening current account deficits. Moreover, rapid credit growth has been a recent feature of financial development in all countries and thus constitutes the main financial stability challenge. In general, monetary authorities have responded to these challenges by tightening monetary conditions and prudential standards, with concrete measures also reflecting the different monetary and exchange rate regimes in the region. The paper also highlights four specific features of financial development in the countries under review, namely the dominance of banks in financial intermediation, the strong participation of foreign-owned banks, the widespread use of foreign currencies and the strengthening of supervisory frameworks.

Key words: South-East Europe, macroeconomic performance, credit growth, financial stability

JEL classification: E65, G21, G38, O16, P27 
Over the last years, acceding countries (Bulgaria and Romania) and candidate countries (Croatia and Turkey) ${ }^{1}$ have seen strong economic growth, coupled with disinflation or low inflation ${ }^{2}$. Domestic demand, fostered partly by rapid credit growth and strong capital inflows, has been the main engine of growth. In addition, given the increasing integration with the euro area and the EU, export performance has been buoyant, but outpaced by even stronger import growth.

Recently, however, inflation has picked up or disinflation has slowed down, as the expansion of domestic demand has been accompanied by several negative supply shocks, including a significant rise in energy prices, adjustments in regulated prices, exogenous shocks, such as floods, and increasing wage pressures. Current account deficits have remained high or increased from already high levels. External private debt has grown rapidly, as banks and enterprises have substantially increased their borrowing abroad.

Against this background, monetary authorities have tightened monetary conditions. Monetary and exchange rate regimes vary between the countries under review, eliciting different policy responses. Countries with a peg or tightly managed float have mainly relied on tightening prudential measures, raising minimum reserve requirements and introducing limits on credit growth. By contrast, countries with a floating exchange rate regime and inflation targeting have also allowed for nominal exchange rate appreciation and have either raised or curbed the decline in interest rates. Moreover, in all countries, fiscal policy has lent some support to monetary policy in safeguarding macroeconomic stability, as fiscal deficits have either declined or turned into surpluses.

Turning to country-specific developments, the findings are as follows.
Bulgaria's macroeconomic challenges relate to the recent pick-up in headline inflation, which has been driven by strong demand and exogenous factors (oil price developments, adjustments in administered prices, impact of the 2005 flooding on agricultural output), as well as to the increase in its current account deficit and the rise in private external debt in a context of intermediately high total foreign debt levels. Positive fiscal outcomes have resulted in a fall in public external debt, compensating for the rise in private external debt. In the light of strong credit growth, the Bulgarian National Bank (BNB) has adopted restrictive administrative and prudential measures to curb credit expansion. However, with an open capital account, experience suggests that any dampening effect may only be temporary, as such measures tend to be circumvented over time.

Bulgaria's financial sector is largely bankbased, private and foreign-owned, and profitable. Banks are predominantly deposit financed and have relatively high capital reserves. The change in the ownership structure has helped to enhance competition. Rapid credit growth has been associated with a substantial change in the net asset positions of the banking sector vis-à-vis those of the real sector, including the foreign sector. Consequently, banks' net foreign assets have changed from a strongly positive to a slightly negative position. On the asset side of the balance sheet, there has been a shift from foreign assets towards domestic claims. Owing to the relatively small size of the domestic interbank market, claims on other banks have been modest.

Given the rapid rise in loans, in particular to households and for housing, Bulgaria's banking sector is exposed primarily to credit risk. Its exposure to interest rate risk, however, appears limited, although it could lead to an increase in

1 The report does not cover the former Yugoslav Republic of Macedonia which has been recently granted candidate status by the European Council on 17 December 2005, following the Commission's recommendation.

2 The cut-off date for the information included in this report was 30 April 2006 
credit risk if the costs associated with adverse interest rate developments are passed on to customers.

\section{ROMANIA}

The main challenge for the Romanian authorities is to keep disinflation on track, as domestic demand (fostered partly by strong credit growth) is expanding rapidly, wage pressures have been increasing, adjustments in administered prices have been ongoing and energy prices have been persistently high. Formally operating under an inflation targeting regime since August 2005, monetary policy faces the issue of tightening monetary conditions within the constraints posed by the need to prevent unsustainable exchange rate appreciation pressures stemming from large and volatile capital inflows. Fiscal policy therefore remains key to supporting macroeconomic stabilisation. To minimise external vulnerabilities, the main policy challenge is to reduce the current account deficit - albeit largely financed by FDI inflows - that has resulted from strong domestic demand, rising real unit labour costs and appreciation pressures on the leu.

Banking sector development in Romania has been characterised by fast private credit growth, in particular to households (e.g. consumer lending, mortgages). However, expressed as a share of GDP, intermediation is still low. Moreover, the Romanian banking sector is generally composed of well capitalised, profitable and mostly foreign-owned banks.

Credit risk remains the main risk to financial stability in Romania. Private credit growth has been driven by improved consumer confidence, high economic growth and macroeconomic stabilisation. As a substantial share of lending is denominated in foreign currencies, endborrowers face significant foreign exchange rate risk, which could transform into a higher credit risk for banks. Banca Națională a României (BNR) has taken restrictive measures to limit credit growth, in particular foreign currency borrowing, which has been partly induced by spreads between domestic and foreign interest rates. To date, there have been no signs of a deterioration in credit quality. Interest rate risk is also increasing, but is still at a low level.

\section{CROATIA}

Croatia's main macroeconomic challenge relates to external factors. Export performance is highly dependent on tourism, and Croatian exports have been relatively slow in penetrating major export markets. This raises concerns about medium-term competitiveness and may have an impact on the current account. It is therefore important to reverse the trend of rising external debt levels (including those of banks), which is associated with rapid capital inflows. However, monetary policy has little room for manoeuvre, given the tightly managed floating exchange rate regime and the high degree to which financial assets and liabilities are denominated in foreign currency, particularly in euro. Against this background, the Croatian National Bank (CNB) has adopted a series of restrictive administrative and prudential measures to curb both foreign borrowing by banks and domestic credit growth. Since such measures tend to be circumvented in the medium term, fiscal policy ought to play a greater role in the macroeconomic adjustment process, in order to moderate the impact of the sizeable capital inflows.

The Croatian financial sector is largely bankbased, private and foreign-owned, relatively concentrated and generally profitable. Banks are predominantly deposit financed. Rapid credit growth has been associated with a substantial decrease in the net foreign asset position of private banks. Claims on the corporate sector are high, but have been falling vis-à-vis the household sector, partly due to the non-bank and cross-border financing of enterprises. Banking sector assets and liabilities are mainly denominated in or indexed to foreign currencies, mostly the euro. 
Croatia's banking sector is exposed primarily to credit risk. The common indicators of asset quality are still positive, but credit risk may be rising again due to high credit growth. Despite the restrictive measures taken by the CNB, persistently high credit growth to the household sector has led to rapidly rising debt levels and an increasing debt service burden. This is indicative of a considerable rise in credit risk, as most of the exchange and interest rate risk has been passed on to borrowers. Consequently, market risks are likely to resurface through credit risk in the event of large shocks.

\section{TURKEY}

A key challenge for Turkey is to reduce the current account deficit that has resulted from strong domestic demand, capital inflows and the (real) appreciation of the lira. This is particularly important given the unfavourable maturity structure of private external debt. In addition, the level and structure of public debt still constitute a source of vulnerability, highlighting the importance of continued strict adherence to sound fiscal policies.

The Turkish financial sector is showing signs of increasing confidence: the portion of assets and liabilities in local currency is rising, and there is growing foreign interest in Turkish banks, although the share of assets held by foreignowned banks is still comparatively small. In addition, banks are increasingly shifting from simply transforming deposits into government security holdings to "core" banking activities, i.e. lending to the corporate and household sectors. Consequently, credit has been growing rapidly and the maturity of assets has been lengthening.

Credit risk is rising due to strong credit growth, particularly in consumer lending and credit cards. Moreover, the proliferation of new products may create the potential for a build-up of nonperforming loans. Interest rate risk is also rising, as declining interest rates are giving banks an incentive to continue borrowing short-term, exacerbating maturity mismatches. In addition, market risk, in particular interest rate risk, related to Treasury bill holdings is still significant.

\section{SPECIAL FEATURES}

\section{FINANCIAL MARKETS AND NON-BANK FINANCIAL INSTITUTIONS}

Compared with the EU and the new Member States, bond markets, stock markets and nonbank financial institutions in the acceding and candidate countries are relatively small (as a share of GDP) and underdeveloped - with the exception of securities markets in Turkey. This underdevelopment can, inter alia, be attributed to the relatively short history of financial markets and the importance of foreign direct investment (FDI) as an alternative source of capital. However, these markets have experienced rapid development in recent years, driven by a favourable interest rate and external environment, as well as sovereign rating upgrades. Furthermore, there is potential for significant further financial market growth due to a widening demand for financial assets in these countries partly driven by the EU accession process.

Whilst non-bank financial institutions still make up a relatively small share of the financial sector in the acceding and candidate countries, they are growing rapidly and, as a whole, their share has nearly doubled since 2001. The limited size of the non-bank financial institutions indicates that this sector is not likely to significantly affect the stability of the financial system, but as this sector is generally less regulated than the banking sector it warrants vigilance from the policy makers.

\section{THE ROLE OF FOREIGN BANIS}

Over the past five years, the number of foreignowned banks successfully penetrating the banking sectors of the acceding and candidate 
countries has increased substantially. Initially, this was due mainly to greenfield investment, while more recently it has been largely the result of acquisitions related to the privatisation of state-owned banks. Foreign-owned banks, primarily through local branches and subsidiaries, are currently the most important players in the financial sectors in all four countries except Turkey, where foreign involvement is largely in the form of crossborder lending.

The presence of foreign-owned banks yields a number of benefits, including better risk management, greater efficiency through enhanced competition, improved access to finance and a more stable lending environment. Nevertheless, it also entails a number of potential risks. The most important of these include a sudden withdrawal of capital from subsidiaries due to changing financial and economic conditions in home and host countries, as well as the potential for contagion via common creditor effects. Foreign bank presence may have also contributed to the very fast rates of credit growth, as foreign-owned banks compete for market share.

\section{THE ROLE OF FOREIGN CURRENCIES}

Foreign currencies, in particular the euro, play a significant role in the banking sectors of the acceding and candidate countries. Traditionally, deposits were in foreign currencies, reflecting a lack of confidence in the domestic currency due to periods of (hyper) inflation and strong depreciations. While the share of foreign currency deposits rose further in the run-up to the euro cash changeover, it has since gradually declined, albeit remaining at a comparatively high level. By contrast, the share of foreign currency loans in total loans has risen significantly in all countries. This reflects supply and demand effects. On the one hand, households and enterprises ask for foreigncurrency-denominated loans as they carry lower interest rates than loans denominated in domestic currency. On the other hand, given their increasing reliance on foreign borrowing, mainly from parent banks, banks have increasingly lent on to final borrowers in foreign currency to keep their net overall foreign currency positions small.

Since borrowers, in particular households, are typically unhedged, banks' loan portfolios are subject to possibly substantial indirect foreign exchange risks, as a depreciation in the domestic currency could lead to a deterioration in the borrowers' debt servicing capacity. Against this background, monetary authorities have introduced mandatory reserve regulations to discourage banks from further borrowing abroad. Moreover, they have tightened prudential measures and applied moral suasion at the creditor and borrower level to limit these risks. Although such measures have a dampening effect in the short run, experience suggests that they tend to be circumvented over time, as customers either sidestep the regulations or borrow directly from abroad.

\section{THE SUPERVISORY FRAMEWORK}

Banking regulatory and supervisory frameworks have been overhauled in the acceding and candidate countries to address the requirements of the acquis communautaire. Minimum capital requirements have been upgraded, loan classification and provisioning requirements have been progressively tightened and an explicit deposit insurance system has been implemented. However, work is still needed in a number of areas, most importantly in improving cooperation between home and host country supervisors.

The supervision of non-bank financial activities is less developed. Further progress is required to ensure compliance with the acquis on antimoney laundering measures, in terms of legislation and implementation. Thus far, the enforcement of such measures appears to have been weak, partly hampered by corruption, organised crime and a large informal economy. 
Mr Roland Beck

Mr Oscar Calvo-Gonzalez

Mr François Gurtner

Mr Jorim Schraven

Mr Jorge da Silva

Nationale Bank van België/

Banque Nationale de Belgique

Mr Anthony De Lannoy

Bulgarian National Bank

Ceská národní banka

Mr Adam Gersl

Danmarks Nationalbank

Ms Tina Winther Frandsen

Deutsche Bundesbank

Banco de España

Banque de France

Central Bank and Financial

Services Authority of Ireland

Latvijas Banka

Ms Marina Vasjukova

Magyar Nemzeti Bank

Mr Zoltán Szalai

De Nederlandsche Bank

Oesterreichische Nationalbank

Banco de Portugal

Narodowy Bank Polski

Banca Națională a României

Ms Anca Adriana Gãlãtescu

Banka Slovenije

Bank of England
Ms Rita Bessone Basto

Mr Zbigniew Polański

Mr Matjaž Noč

Mr Miquel Dijkman

Mr Peter Backé

Ms Cristiana de-Alessi 


\section{PREFACE}

Over the last years, acceding countries (Bulgaria and Romania) and candidate countries (Croatia and Turkey) ${ }^{3}$ have seen strong economic growth, coupled with disinflation or low inflation. Domestic demand, fostered partly by rapid credit growth and strong capital inflows, has been the main engine of growth. Indeed, banks have expanded credit at a rapid pace, in particular to households and for housing purposes. This has raised financial stability concerns and been accompanied by a widening of external imbalances, despite a buoyant export performance, as it has been outpaced by even stronger import growth.

More recently, inflation has picked up or disinflation has slowed down, as the expansion of domestic demand has been accompanied by several negative supply shocks, including a significant rise in energy prices, adjustments in regulated prices, exogenous shocks, such as floods, and increasing wage pressures. Current account deficits have remained high or increased from already high levels. External private debt has grown rapidly, as banks and enterprises have substantially increased their borrowing abroad.

These developments have taken place in financial sectors that are generally characterised by:

- a recovery from crisis-like developments in the late 1990s and early 2000s, and, in the case of Bulgaria, Romania and Croatia, an ongoing transition process, showing strong progress in financial intermediation;

- a dominance of banks vis-à-vis other financial intermediaries and markets;

- strong participation by foreign-owned banks (with the notable exception of Turkey), either in the form of local subsidiaries and branches and/or cross-border lending;

- the widespread use of foreign currencies, in particular the euro; and
- a strengthening of the supervisory framework.

Against this background, in October 2005, the International Relations Committee (IRC) of the European System of Central Banks (ESCB) established a Task Force, comprising participants from the ECB and the national central banks of the ESCB, to analyse macroeconomic and financial stability challenges facing the acceding and candidate countries. The ensuing report - on which this occasional paper is based - was reviewed by the IRC in March 2006. Moreover, it served as input to the dialogue between the Economic and Financial Committee (EFC) and acceding and candidate countries in April/May $2006 .{ }^{4}$

The report is structured around four countryspecific chapters. Following this brief introduction, each chapter deals first with macroeconomic developments and vulnerabilities in each country and then goes on to discuss the respective banking sectors in terms of both structure as well as risks and shock-absorbing capacities. This focus on the banking sector is justified given the still limited - albeit growing - importance of non-bank financial institutions in the countries under consideration. Financial markets and other non-bank financial institutions are nevertheless dealt with in the first of four special features that complement the countryspecific chapters by focusing on specific issues relevant to all four countries. The other three special features deal with the role of foreign banks, the use of foreign currencies and potential currency mismatches, and finally, the supervisory frameworks.
3 The report does not cover the former Yugoslav Republic of Macedonia which has been recently granted candidate status by the European Council on 17 December 2005, following the Commission's recommendation.

4 The cut-off date for the information included in this report was 30 April 2006. 


\section{BULGARIA}

\section{I MACROECONOMIC DEVELOPMENTS AND VULNERABILITIES}

\section{DEVELOPMENT OF BULGARIA'S EXTERNAL \\ ENVIRONMENT}

Bulgaria is a highly open economy with full capital mobility. Total exports and imports of goods are approaching the value of GDP; if services are also taken into account, the ratio exceeds $100 \%$ and has done so since the beginning of this decade. Bulgaria's balance of payments current account is fully liberalised and virtually all capital account transactions are free from administrative restrictions.

Bulgaria's main trading partner is the EU, which accounts for nearly $60 \%$ of its foreign trade. Approximately half of its total turnover is generated through the euro area. Other important trading partners are countries in the South-Eastern European region, mainly Turkey and Romania. In terms of product structure, Bulgaria exports mainly raw materials and consumer goods. On the imports side, Bulgaria's principal trading items are raw materials (especially energy resources, such as oil and gas) and investment goods.

Bulgaria benefited from favourable external financing conditions, as spreads on euro and US dollar-denominated government bonds have been falling to record lows. Claims by euro area BIS reporting banks have risen substantially, partly reflecting heightened activity by euro area banks in the country. On 1 March 2006, Moody's upgraded Bulgaria's long-term foreign currency rating from $\mathrm{Ba} 1$ to Baa3, becoming the last major rating agency to grant investmentgrade status.

\section{DEVELOPMENT OF BULGARIA'S DOMESTIC MACROECONOMIC ENVIRONMENT}

Since the beginning of the decade, strong real GDP growth has been underpinned by domestic demand expansion. In 2004 and 2005, growth exceeded $5 \%$. Investment has been the most dynamic component of domestic demand, with

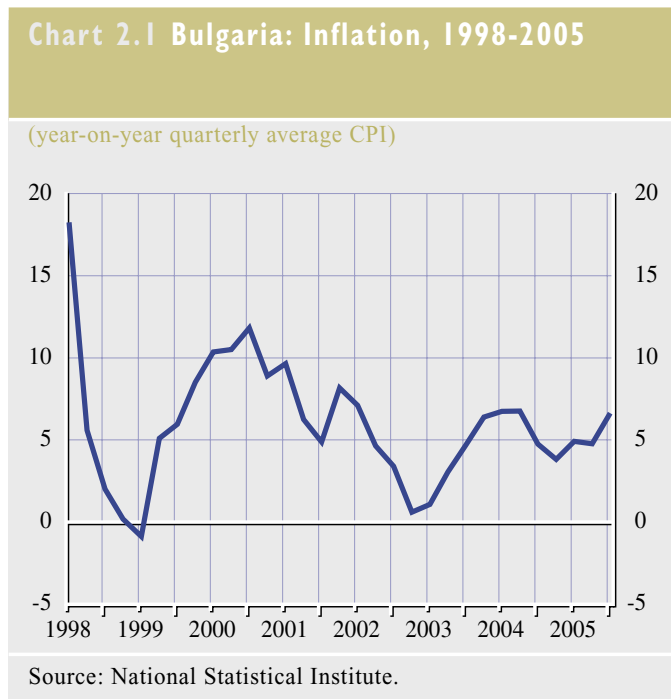

growth rates surpassing $10 \%$ annually since the beginning of the decade (except in 2002), leading to an investment-to-GDP ratio above $23 \%$ in recent years. This increase in investment activity resulted in the technical modernisation of the enterprise sector, which boosted productivity and the quality of produced goods, and in turn improved the sector's competitiveness, as shown by the strong growth in industrial output since 2003 .

The Currency Board Arrangement (CBA), adopted in July 1997 in the aftermath of a deep economic and financial crisis, is credibly established and has been instrumental in providing monetary stability. ${ }^{5}$ Financial ratios describing its operation have been high: in 2005, the ratios of foreign reserves to reserve money and to M1 stood above the levels of other CBAs in the region at $173 \%$ and $96 \%$ respectively. The performance of the CBA has been supported by a sound fiscal policy and the implementation of key structural reforms, such as bank restructuring and privatisation.

However, inflation has been volatile. Following the rapid fall in inflation in the late 1990s, it has bounced back twice: at the turn of the century and after 2003 (see Chart 2.1). In addition to

5 The lev was initially anchored (at par) to the Deutsche Mark, and since the beginning of 1999 it has been anchored to the euro (lev/euro parity rate at 1.95583 ) 
strong demand, the second inflation hike was driven mainly by three factors: oil price developments, shortages of some agricultural products (due to the floods in summer 2005), and an increase in the prices of electricity and central heating in the second half of the year. At the end of 2005, year-on-year consumer price inflation reached $6.5 \%$, up from $4.0 \%$ in December 2004.

Strong credit growth has been a major challenge for Bulgaria in the last three years, as domestic credit has expanded by more than $30 \%$ annually. The growth in claims on the non-government sector, and in particular, claims on households and non-profit institutions serving households (NPISHs), was even higher: in 2004, the former increased by $48.6 \%$ (its stock reaching $37.1 \%$ of GDP), while the latter rose by $74.8 \%$ (its stock reaching $11.5 \%$ of GDP). These developments took place in an environment of declining real interest rates. In fact, except for 2003 , interest rates on deposits have been negative in real terms. In 2005, the Bulgarian National Bank (BNB) issued several regulations to limit the growth of credit to the nongovernment sector. These were to some extent effective, as the annual growth rate of claims on the non-government sector as well as on households and NPISHs decreased to $32.4 \%$ and $58.4 \%$ respectively at the end of 2005 .

Against this background, prudent fiscal policy, supported by strong growth, has contributed to macroeconomic stability since 1997. The general government's primary balance has been positive over the decade and the public debt-toGDP ratio has been declining steadily (see Table 2.1) thanks to continued fiscal restraint, rapid economic growth and active debt

\section{Chart 2.2 Bulgaria: Real GDP and real domestic demand growth, 2000-05}

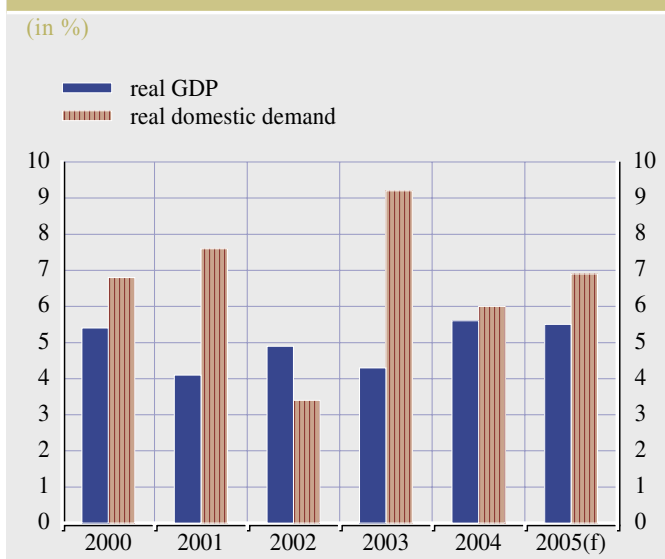

Sources: IMF, national authorities Note: $(\mathrm{f})=$ forecast

management. Counter-cyclical fiscal policy has been key in mitigating the potentially destabilising effects of strong domestic demand. Indeed, under the CBA, fiscal policy is the only macroeconomic instrument at the disposal of the authorities for accommodating possible external shocks. The fiscal policy stance will therefore remain crucial, especially given the authorities' stated objective of seeking to join the euro area in 2009.

Domestic demand developments have also had a visible impact on the external position of the Bulgarian economy, as the current account deficit has increased sharply, reaching almost $12 \%$ of GDP in 2005. The trade deficit has been the main driver of current account imbalances, given the permanently positive services balance (due to strong tourism revenues). Trade developments mainly reflected changes in the prices of energy resources on the international

\section{Table 2.I Bulgaria: General government balance and debt, 2000-05}

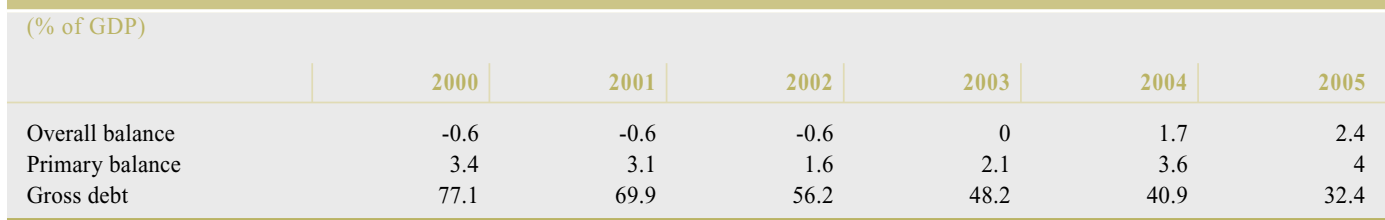

Source: Ministry of Finance. 
Table 2.2 Bulgaria: Balance of payments selected items, 2000-05

\begin{tabular}{|c|c|c|c|c|c|c|}
\hline \multicolumn{7}{|l|}{ (\% of GDP) } \\
\hline & 2000 & 2001 & 2002 & 2003 & 2004 & 2005 \\
\hline Current account balance & -5.6 & -5.6 & -2.4 & -5.5 & -5.8 & -11.8 \\
\hline Trade balance & -9.4 & -11.7 & -11.4 & -13.7 & -15.1 & -20.4 \\
\hline Services balance & 4 & 2.2 & 3.1 & 3.1 & 3.5 & 3.1 \\
\hline Financial account balance & 6.6 & 5.0 & 11.1 & 13.2 & 14.9 & 13.4 \\
\hline Net foreign direct investment & 8 & 5.9 & 5.8 & 10.3 & 11.5 & 8.7 \\
\hline Net portfolio investment & -1.4 & 0.6 & -0.6 & -1.1 & -2.9 & -3.5 \\
\hline Change in reserve assets & 3.6 & 2.1 & 3.5 & 4.6 & 7.6 & 1.5 \\
\hline
\end{tabular}

markets (Bulgaria is heavily dependent on fuel imports) and rapidly growing physical volumes of imports. Since 2003, the growth rate of the latter has exceeded that of exports, signalling strong domestic demand.

While the CPI-based real effective exchange rate has been appreciating (see Chart 2.3), unit labour costs have been decreasing due to the rapid rise in productivity. Bulgaria's competitiveness has therefore been improving, as real unit labour costs are below the levels of 1998. In manufacturing, real unit labour costs are even expected to decrease further as a result of investment growth.

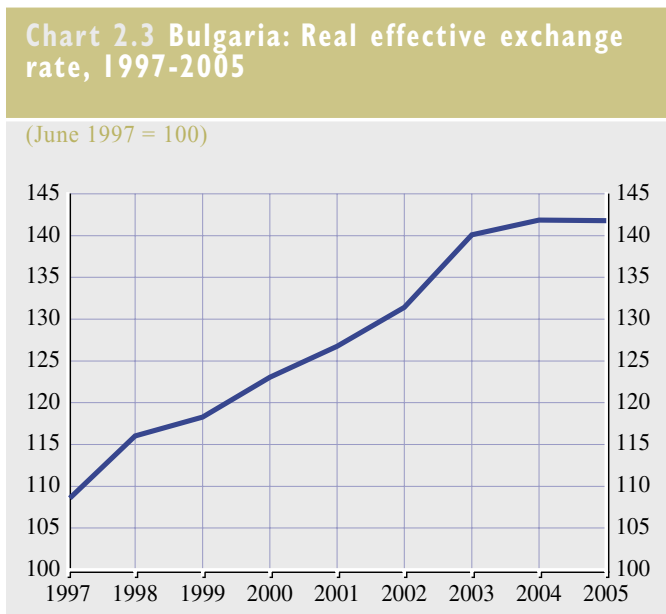

Source: BNB.

Note: The real effective exchange rate index is a monthly average and is based on the relative weights in the manufacturing trade for 1999-2001. Consumer prices are used as a measure to deflate the nominal exchange rates. The index is calculated as a basket of the 19 countries of greatest importance for Bulgarian period.
The widening of the current account deficit in recent years above all reflects strong investment growth, stimulated by the inflow of foreign capital and insufficient domestic saving. Such a pattern of economic development is typical of countries reaching a more advanced stage of transition where reforms and privatisation stimulate the modernisation of the economy. Indeed, imports of investment goods have been growing quickly, reaching $27.6 \%$ of total imports in 2005. Furthermore, the increased borrowing of banks from abroad has been an important factor in the strong credit expansion.

The large trade and current account deficits have so far not posed serious threats to macroeconomic and financial stability. This is partly because, in recent years, a substantial part of the current account deficit has been financed by large FDI inflows. Moreover, active debt management policies reduced the stock of public debt (see Table 2.1), for instance through the buyback of outstanding Brady bonds, and changed the currency composition structure of foreign debt, by increasing the share of eurodenominated instruments for example. Consequently, total external debt has stabilised at around $65 \%$ of GDP, despite the growth in private external debt, and its currency structure has become more similar to the currency structure of payments resulting from trade flows. Bulgaria's external debt is mostly composed of instruments with longer-term maturities, although the share of short-term debt has increased since 2001, reaching approximately $25 \%$ of total gross external debt 
in 2005. Finally, international reserves increased from around USD 3 billion in 2002 to around USD 9 billion in early 2005 and have remained at around that level.

Reducing the current account deficit will be an important challenge for the authorities, as capital inflows may become more volatile over time, even though inflows other than privatisation proceeds have been relatively stable in the last few years. In view of the large external imbalances, the containment of demand pressures and the enhancement of supply capacities are the crucial challenges for the authorities in preserving economic and financial stability. In practice, this includes continued adherence to prudent fiscal policies and wage restraint.

\subsection{THE BULGARIAN BANIING SECTOR}

\section{STRUCTURE AND DEVELOPMENTS}

\section{A short history of the Bulgarian banking \\ system}

The early transition years were characterised by soft budget constraints as well as the currency and financial crisis in 1997. At the end of 1989, the former socialist one-tier banking system comprising the Bulgarian National Bank (BNB), the Bulgarian Foreign Trade Bank and the State Savings - was transformed into a two-tier system. On the legal front, the Law on the Bulgarian National Bank and the Law on Banks and Credit Activity came into effect in 1991 and 1992 respectively. Despite these reforms, however, the regulatory and supervisory framework was still not appropriate and banks operated in an environment characterised by soft budget constraints (related party lending and lending to state-owned enterprises), which ultimately resulted in a credit boom and a surge in non-performing loans $(74 \%$ of the total in 1995). The BNB tried to prevent large banks from failing by providing more loans, but it lost control over the money supply. This resulted in a severe currency and financial crisis in the years 1996-97, which was compounded by a period of hyperinflation.
The strengthening of supervision and regulation, privatisation and foreign ownership have been key elements in the post-crisis strategy based on the $C B A$. Several measures were introduced in 1997 to combat the crisis, the most important of which was the CBA, aimed at asserting strict control over money supply. At the same time, a new banking law and a new law on the BNB were adopted, prudential regulations and supervision were strengthened, and a deposit insurance fund was introduced. The crisis also marked the beginning of the privatisation of the banking sector, with foreign investors, who had not entered the Bulgarian market until 1994, becoming major players.

\section{The current structure of the banking system}

The Bulgarian banking sector is now mostly private and foreign-owned and conditions have improved considerably since the crisis. The EBRD index of banking sector reform increased from 2.7 in 1999 to 3.7 in 2005, reaching a level similar to that of the new EU Member States (NMS) (see Table 2.3). Since 1997, the number of banks has remained stable around 35 , but the bank density (number of banks per 100,000 inhabitants) has risen slightly to 0.45 , which is higher than in the NMS- $8^{6}(0.29)$ but marginally lower than in the euro area $(0.54)$. The number of state banks has gradually declined, but the asset share of private banks increased from 53\% in 1999 to around $98 \%$ at the end of 2004 . Similarly, the share of total banking assets held by foreign-owned banks (which include the country's five largest banks) rose from $18 \%$ in 1997 to approximately $80 \%$ by the end of 2004 . This share is even higher than the average of the NMS-8 (77\% at the end of 2004) and much higher than that of the euro area (22\%).

The change in the ownership structure has helped to enhance competition in the Bulgarian banking sector. This is illustrated by the change in the level of concentration and the evolution of the spread between lending and deposit rates. The five largest banks accounted for around $52 \%$ of total banking assets at the end of 2004 ,

\footnotetext{
6 NMS-8 stands for the new Member States, excluding Cyprus
} and Malta. 
Table 2.3 The structure of the Bulgarian banking sector

\begin{tabular}{|c|c|c|c|c|c|c|c|}
\hline & 1999 & 2000 & 2001 & 2002 & 2003 & 2004 & 2005 \\
\hline EBRD index of banking sector reform & 2.7 & 3.0 & 3.0 & 3.3 & 3.3 & 3.7 & 3.7 \\
\hline Number of banks (of which state-owned ${ }^{1}$ ) & $34(6)$ & $35(4)$ & $35(4)$ & $34(3)$ & $35(2)$ & $35(2)$ & $34(2)$ \\
\hline (per 100,000 inhabitants) & 0.4 & 0.4 & 0.4 & 0.4 & 0.5 & 0.5 & 0.4 \\
\hline Number of branches of banks & 659 & 717 & 738 & 744 & 755 & 714 & 653 \\
\hline (per 100,000 inhabitants) & 8.1 & 8.8 & 9.4 & 9.5 & 9.7 & 9.2 & 9 \\
\hline Asset share of private banks (\%) & 53.0 & 80.2 & 80.1 & 85.9 & 97.5 & 97.7 & 98.3 \\
\hline Asset share of foreign banks (\%) & 42.8 & 75.3 & 72.7 & 75.2 & 82.7 & 81.6 & 80.09 \\
\hline Asset share of five largest banks (\%) & 62.3 & 60.4 & 56.6 & 55.3 & 52.9 & 52.2 & 50.83 \\
\hline Herfindahl-Hirschmann index ${ }^{2)}$ & 1,159 & 1,094 & 930 & 835 & 563 & 634 & 697 \\
\hline Interest rate spread ${ }^{3)}$ & 9.8 & 11.7 & 11.1 & 10.3 & 9.2 & 8.6 & 8.7 \\
\hline
\end{tabular}

Sources: BNB, Walko (2004) and Walko and Reininger (2005).

1) Including municipal banks.

2) Sum of the squared asset shares of individual banks. (It ranges between 0 and 10,000. Below 1,000 it suggests a non-concentrated sector; above 1,800 it is highly concentrated).

compared with $62 \%$ in 1999 . This concentration level is lower than in the NMS-8 (68.6\%) and similar to that of the euro area. The HerfindahlHirschman index also shows a decline in concentration. Furthermore, the drop in the spread between lending and deposits rates suggests that the change in structure has boosted competition in the Bulgarian banking system.?

\section{The structure of bank assets and liabilities}

Banking intermediation in Bulgaria is still relatively low compared with the euro area (see Table 2.4). This is partly due to the low level of per capita income, but can also be attributed to the financial crisis, when the ratio of banking sector assets to GDP dropped significantly from $180 \%$ in 1996 to $37 \%$ in 1999 . Although asset growth was rather subdued in the late 1990s, reflecting banks' efforts to clean up portfolios before privatisation and increased risk aversion, it has since then been robust. Total banking sector assets increased on average by about

7 It should be noted that a lower concentration level does not always signify greater competition. Moreover, the interest rate spread may be affected by factors other than competition, e.g. the quality of the loan portfolio.

\section{Table 2.4 Asset structure of the Bulgarian banking sector}

\begin{tabular}{|c|c|c|c|c|c|c|c|}
\hline & 1999 & 2000 & 2001 & 2002 & 2003 & 2004 & 2005 \\
\hline $\begin{array}{l}\text { Total domestic claims }{ }^{1)} \text { in } \% \text { of total assets } \\
\text { on monetary financial institutions }\end{array}$ & 57.5 & 51.4 & 54.5 & 64.5 & 72.6 & 74.8 & 77.0 \\
\hline (incl. central bank) & 11.2 & 8.4 & 9.2 & 9.8 & 9.2 & 11.9 & 14.5 \\
\hline on general government & 13.9 & 10.6 & 10.7 & 12.9 & 11.3 & 8.7 & 8.0 \\
\hline on households & 5.9 & 6.0 & 7.3 & 9.1 & 13.8 & 16.9 & 20.3 \\
\hline on non-bank corporations & 26.5 & 26.5 & 27.3 & 32.6 & 38.2 & 37.4 & 34.2 \\
\hline Domestic loans in $\%$ of total assets & 39.9 & 36.8 & 36.2 & 40.6 & 46.3 & 48.7 & 55.7 \\
\hline Securities in $\%$ of total assets & 10.2 & 7.3 & 7.8 & 10.4 & 9.2 & 7.8 & 13.1 \\
\hline External assets in $\%$ of total assets & 32.8 & 39.4 & 36.3 & 25.1 & 16.6 & 17.3 & 15.9 \\
\hline Fixed assets in $\%$ of total assets & 5.8 & 5.7 & 5.5 & 5.8 & 5.8 & 4.7 & 4.2 \\
\hline Other assets in $\%$ of total assets & 3.9 & 3.5 & 3.7 & 4.6 & 5.0 & 3.2 & 1.6 \\
\hline \multicolumn{8}{|l|}{ Memo } \\
\hline Total assets in $\%$ of GDP & 34.4 & 36.5 & 41.1 & 45.0 & 50.3 & 65.6 & 78.3 \\
\hline Credit to the private sector in $\%$ of GDP & 12.1 & 12.6 & 14.9 & 19.8 & 27.6 & 37.1 & 44.5 \\
\hline Real growth of credit to the private sector (\%) & 13.5 & 5.1 & 26.0 & 38.7 & 40.4 & 43.0 & 24.4 \\
\hline $\begin{array}{l}\text { Share of loans to households and enterprises } \\
\text { with maturity of up to one year }\end{array}$ & 37.3 & 34.1 & 32.7 & 31.5 & 25.2 & 24.2 & 22.7 \\
\hline
\end{tabular}

Sources: BNB, IMF (IFS), Walko (2004), Walko and Reininger (2005), Hilbers et al. (2005).

1) Claims are credits, securities and repurchase agreements. 
6 percentage points of GDP per annum, reaching $68 \%$ of GDP at the end of 2004 , compared with $75 \%$ in the NMS- 8 and more than $280 \%$ in the euro area.

On the asset side of banks'balance sheets, there has been a shift from foreign assets towards domestic claims. External assets declined from $40 \%$ of total assets in 2000 to $17 \%$ of total assets in 2004, while total domestic claims increased from $50 \%$ of total assets in 2000 to around $75 \%$ of total assets at the end of 2004 (77\% in the NMS- 8 and $79 \%$ in the euro area). This development has been driven by the rise in claims on households and non-banks. Their joint share in total assets increased from $32 \%$ in 1999 to $54 \%$ in 2004 ( $40 \%$ in the euro area). While the bulk of banks' domestic claims are on non-bank corporations $(37 \%$ of total assets or about $50 \%$ of total domestic claims), claims on households almost tripled as a percentage of total assets between 1999 and 2004 (from 6\% to $17 \%$ ), also reflecting increased lending activity for house purchases. At the same time, claims on general government (mostly in the form of securities) declined from $13.9 \%$ of total assets in 1999 to $8.7 \%$ of total assets in 2004 .

Owing to the relatively small size of the domestic interbank market, claims on other banks are modest. Claims on the central bank and gross claims on resident commercial banks represented
$11.9 \%$ of the total gross assets of Bulgarian banks at the end of 2004. The former outpaced the growth of the latter, mainly due to an increase in the reserve requirements and a small interbank market.

Bulgarian banks are predominantly deposit financed and have relatively high capital reserves. Domestic sector deposits have accounted for around two-thirds of total liabilities over the last few years, although this share declined from $71.1 \%$ to $64.1 \%$ in 2004 , due to a sharp increase in foreign liabilities (see Table 2.5). Deposits of households and nonbank corporations remain the largest liability, accounting for $56 \%$ of total liabilities. The share of deposits of general government and of monetary financial institutions in total deposits has hovered around 3-5\% respectively, similar to that of the NMS-8 (in the euro area, deposits of monetary financial institutions account for $22 \%$ of total liabilities). At the end of 2004 , capital and reserves amounted to $10.5 \%$ of total liabilities, which represented a steady decline from $14.5 \%$ in 1999 , but was still significantly more than in the euro area $(5.6 \%)$ and similar to the NMS- 8 average.

Rapid credit growth has been associated with a substantial change in the banking sector's net asset positions vis-à-vis the real sector. During the late 1990s, banks maintained a large negative

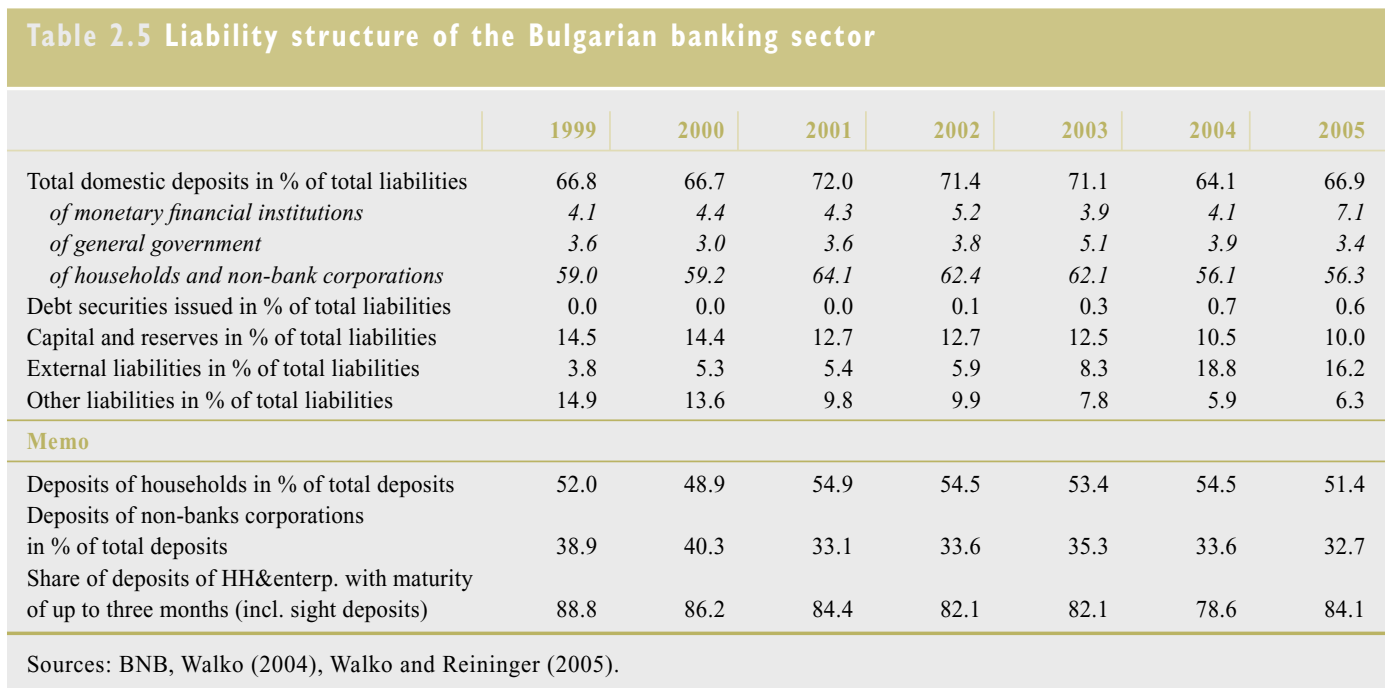


Table 2.6 Banking sector's aggregated balance sheet net position')

\begin{tabular}{|c|c|c|c|c|c|c|c|}
\hline & 1999 & 2000 & 2001 & 2002 & 2003 & 2004 & 2005 \\
\hline $\begin{array}{l}\text { Net claims on domestic monetary financial } \\
\text { institutions in \% of total assets }\end{array}$ & 7.0 & 4.0 & 4.9 & 4.6 & 5.3 & 7.8 & 8.7 \\
\hline $\begin{array}{l}\text { Net claims on general government } \\
\text { in } \% \text { of total assets }\end{array}$ & 10.3 & 7.6 & 7.2 & 9.1 & 6.2 & 4.8 & 4.9 \\
\hline $\begin{array}{l}\text { Net claims on households and } \\
\text { non-bank corporations in \% of total assets }\end{array}$ & -26.6 & -26.8 & -29.6 & -20.7 & -10.0 & -1.9 & -1.2 \\
\hline Net external assets in $\%$ of total assets & 29.0 & 34.1 & 30.9 & 19.2 & 8.3 & -1.5 & 0.6 \\
\hline Other assets, net, in \% of total assets & -5.2 & -4.4 & -0.6 & 0.5 & 2.7 & 1.3 & 0.2 \\
\hline Capital and reserves in $\%$ of total liabilities & 14.5 & 14.4 & 12.7 & 12.7 & 12.5 & 10.5 & 10.0 \\
\hline
\end{tabular}

Sources: BNB, Walko (2004), Walko and Reininger (2005).

1) Net positions calculated as claims minus deposits (repurchase agreements, debt securities issued, credits received and equity are not taken into account on the liability side).

net position against households and non-bank corporations, partly due to the sharp contraction of lending activity after the crisis. This was accompanied by a positive net position against the general government. Since 2002, however, the rapid growth of credit to the corporate and household sectors has improved the net position from $-29.6 \%$ of total assets in 2001 to $-1.2 \%$ of total assets in 2005 (see Table 2.6). This has been matched by a decrease in the net external position of the banking sector, as foreign liabilities have been increasing at the same time as the share of external assets in total assets has been declining. There has also been a drop in the net position against the government in recent years, partly due to the sound fiscal policies that have been implemented under the CBA. Finally, banks have also held a positive net position against domestic monetary financial institutions, essentially as a result of the position against the monetary authority.

The profitability of the banking system

The profitability of the Bulgarian banking system has remained fairly stable and relatively high over the past few years. Return on assets has fluctuated between $2 \%$ and $3 \%$ (compared with $0.4 \%$ in the euro area in 2004), while return on equity initially increased to $22 \%$ in 2000 and 2001, then fell back to between $16 \%$ and $19 \%$ in 2002 and 2003, and increased again to above $20 \%$ since 2004 (see Table 2.7). Despite

\section{Table 2.7 Profitability of the Bulgarian banking sector}

\begin{tabular}{|c|c|c|c|c|c|c|c|}
\hline & 1999 & 2000 & 2001 & 2002 & 2003 & 2004 & 2005 \\
\hline Net interest income in $\%$ of average assets & 4.6 & 4.6 & 4.3 & 3.9 & 4.7 & 4.9 & 4.8 \\
\hline Net non-interest income in $\%$ of average assets & 5.7 & 5.9 & 3.5 & 3.2 & 2.4 & 2.3 & 2.1 \\
\hline Operating income in $\%$ of average assets & 10.3 & 10.5 & 7.8 & 7.1 & 7.2 & 7.3 & 6.7 \\
\hline Ratio of net interest income in operating income & 44.5 & 43.7 & 55.1 & 55.0 & 65.9 & 68.1 & 78.0 \\
\hline Operating costs in $\%$ of average assets & 5.8 & 5.3 & 5.0 & 4.5 & 4.5 & 4.2 & 3.6 \\
\hline Personnel costs in $\%$ of operating costs & 36.1 & 41.4 & 39.7 & 38.5 & 37.8 & 36.7 & 22.2 \\
\hline Cost-to-income ratio & 56.7 & 49.9 & 64.1 & 63.5 & 63.0 & 58.3 & 55.9 \\
\hline $\begin{array}{l}\text { Net costs of loan loss provisioning } \\
\text { in } \% \text { of average assets }\end{array}$ & 0.7 & 0.9 & -0.7 & 0.1 & 0.3 & 0.7 & 0.8 \\
\hline $\begin{array}{l}\text { Net costs of loan loss provisioning } \\
\text { in } \% \text { of operating income }\end{array}$ & 6.6 & 8.6 & -8.7 & 1.3 & 3.7 & 9.4 & 13.5 \\
\hline Return on assets & 2.5 & 3.1 & 2.7 & 1.9 & 2.0 & 2.0 & 2.0 \\
\hline Return on equity ${ }^{1)}$ & 20.9 & 22.6 & 21.9 & 15.9 & 18.7 & 20.0 & 21.6 \\
\hline
\end{tabular}

Sources: BNB, Walko (2004) and Walko and Reininger (2005).

1) Estimates for return on equity provided by Walko (2004) and Walko and Reininger (2005): $16.6 \%$ in $1999 ; 19.8 \%$ in $2000 ; 19.2 \%$ in $2001 ; 14.4 \%$ in $2002 ; 15.0 \%$ in 2003 and $16.8 \%$ in 2004 
the reduction in spreads, net interest income recovered from $3.9 \%$ of average assets in 2002 to $4.8 \%$ in 2005 , compared with $1.2 \%$ in the euro area and $2.7 \%$ in the NMS. This evolution has been due to the rapid credit growth to domestic sectors and the simultaneous decrease in the net foreign assets position, as interest income on domestic assets significantly exceeds that on foreign assets. Non-interest income has decreased in recent years, from $5.9 \%$ of average assets in 2000 to $2.1 \%$ in 2005 . Consequently, operating income, as a percentage of average assets, declined between 1999 and 2002 and then stabilised at around $7 \%$, while the share of net interest income in total operating income rose from $44.5 \%$ in 1999 to $78.0 \%$ in 2005 .

Operating costs have fallen but remain relatively high. Operating costs gradually decreased from $5.8 \%$ of average assets in 1999 to $3.6 \%$ in 2005 . This can be partly attributed to restructuring measures following privatisation. Costs nevertheless remain higher than in the euro area $(1.5 \%)$ and in the NMS $(2.8 \%)$. Loan loss provisioning contributed to gross profits in 2001 due to the release of large reserves ( $9 \%$ of operating income) that were created between 1999 and 2000. Since then, in the light of the rapid credit expansion, ${ }^{8}$ reserve provisions have increased, reaching $13.5 \%$ of operating income in 2005 .

\section{RISKS AND SHOCK-ABSORBING CAPACITIES}

The Bulgarian banking system is generally well supervised, highly capitalised and profitable. However, credit growth has continued to accelerate in recent years, which may have increased financial stability risks. Since 2000, real domestic credit in Bulgaria has grown on average by more than $30 \%$ annually (see Table 2.8). Credit growth boosts financial deepening and can largely be considered a catching-up phenomenon brought about by deregulation, liberalisation and privatisation. It allows for a better allocation of savings to investment opportunities and facilitates higher growth. Although no significant deterioration in bank loan portfolios has been observed, most financial sector indicators are "lagging", thus credit growth developments require close monitoring.

While credit growth is high, the level of private sector credit is still relatively low and the debt burden of households and enterprises appears to remain contained. Financial intermediation in Bulgaria is still limited by international standards, as evidenced by a private banking credit-to-GDP ratio of $45 \%$ (2005). Lending to households and mortgage lending have risen particularly quickly in recent years (see Table 2.8), albeit from very low levels. Household debt amounts to around $16 \%$ of GDP (2005), which, together with a comparatively low ratio of interest payments to disposable income of around $1 \%$ (that of the euro area was $4.5 \%$ in 2004), does not constitute a heavy debt service burden. Non-financial enterprises account for the bulk of domestic credit $27.6 \%$ of GDP in $2005)$, their debt amounting to almost twice their deposits and their interest payments totalling around $2 \%$ of GDP. In terms of credit concentration, the largest exposures are to the processing industry $(22.3 \%)$, the hotel industry $(6.7 \%)$ and the construction industry $(5.6 \%)$.

Market developments, however, may potentially translate into credit risk. The share of foreign currency lending is increasing and accounts for almost half of total lending, but credit risk associated with increased foreign currency exposure of the private sector is limited, given the CBA and the fact that lending in currencies other than the lev or the euro is almost insignificant (see below). An increase in interest rates from their current low levels could affect borrowers more significantly. However, as the portion of disposable income spent on interest payments is relatively low, the capacity of households to service their debt may withstand a potential increase in interest rates.

8 The ratio of non-performing loans to total loans has shown a steady decline over the last few years (from $14 \%$ in 1997 to $2 \%$ in 2004), but, given the strong credit growth, banks have increased their provision of reserves as a precautionary measure. 
Table 2.8 Bulgaria: Selected banking sector stability indicators

\begin{tabular}{|c|c|c|c|c|c|c|}
\hline & 2000 & 2001 & 2002 & 2003 & 2004 & 2005 \\
\hline \multicolumn{7}{|l|}{ Risks } \\
\hline \multicolumn{7}{|l|}{ Credit risk } \\
\hline Credit growth (annual percentage change) & 31.0 & 26.0 & 27.4 & 33.9 & 34.2 & 33.0 \\
\hline Credit growth to the private sector (annual percentage change) & 17.0 & 32.1 & 44.0 & 48.3 & 48.6 & 32.4 \\
\hline Real credit growth to the private sector (annual percentage change) & 5.1 & 26.1 & 38.7 & 40.4 & 43.0 & 24.6 \\
\hline Credit growth to households (annual percentage change) ${ }^{1)}$ & 17 & 52.4 & 47.6 & 82.3 & 60.6 & 46.9 \\
\hline Housing credit growth (annual percentage change) & 26.8 & 44.4 & 51.8 & 70.9 & 149.9 & 97.4 \\
\hline Non-performing loans ( $\%$ of total loans) & 7.9 & 3.3 & 2.4 & 3.2 & 2 & 2.2 \\
\hline Non-performing loans net of provisions (as percentage of capital) & 2.6 & 3.2 & 3.5 & 2.9 & 1.5 & 2.6 \\
\hline $\begin{array}{l}\text { Share of foreign currency credit in total private sector credit } \\
\text { (share of non-euro credit) }\end{array}$ & 35.4 & 35.5 & 41.3 & 42.8 & $\begin{array}{r}47.5 \\
5.9\end{array}$ & $\begin{array}{r}47.3 \\
3.8\end{array}$ \\
\hline $\begin{array}{l}\text { Share of foreign currency deposits in total deposits } \\
\text { (share of non-euro deposits) }\end{array}$ & 59.2 & 58.3 & 54.6 & 52.4 & $\begin{array}{l}46.7 \\
19.8\end{array}$ & $\begin{array}{l}46.5 \\
17.8\end{array}$ \\
\hline Growth of foreign liabilities (annual percentage change) & 63.6 & 27.3 & 28.2 & 67.7 & 224.8 & 14.0 \\
\hline Share of foreign liabilities in total liabilities and equity & 7.1 & 7.0 & 7.7 & 10.9 & 27.5 & 24.0 \\
\hline \multicolumn{7}{|l|}{ Market risk } \\
\hline \multicolumn{7}{|l|}{ Foreign currency risk } \\
\hline Ratio of non-euro loans to non-euro deposits & & & & & 28.8 & 21.1 \\
\hline$\%$ mismatch on total deposits & & & & & 14.1 & 14.0 \\
\hline Open FX position in $\%$ of total balance sheet assets & -0.77 & -0.85 & -0.67 & -0.58 & -0.35 & -0.53 \\
\hline \multicolumn{7}{|l|}{ Interest rate risk } \\
\hline Ratio of short-term loans (up to three months) to short term deposits & 78.7 & 67.8 & 55.8 & 38.2 & 44.2 & 45.4 \\
\hline$\%$ mismatch on total deposits & 16.3 & 24.5 & 33.4 & 48.2 & 41.8 & 39.5 \\
\hline Short-term deposits, as a percentage of total deposits & 76.6 & 76.2 & 75.6 & 78.0 & 74.9 & 72.3 \\
\hline Short-term loans, as a percentage of total loans & 58.2 & 55.6 & 46.6 & 33.2 & 36.0 & 34.6 \\
\hline \multicolumn{7}{|l|}{ Liquidity risk } \\
\hline Liquid assets (cash + securities), as percentage of total assets & 22.9 & 27.2 & 28.0 & 20.0 & 18.6 & 18.4 \\
\hline Ratio of short-term assets on short-term liabilities & 117.0 & 111.3 & 101.2 & 68.9 & 72.9 & 75.1 \\
\hline \multicolumn{7}{|l|}{ Shock-absorbing factors } \\
\hline Return on average assets (in \%) & 2.9 & 2.6 & 1.8 & 2.2 & 1.7 & 1.8 \\
\hline Return on average equity (in \%) & 18.8 & 19.3 & 13.8 & 16.7 & 15.9 & 17 \\
\hline Net interest margin & 8.4 & 8.2 & 6.6 & 5.9 & 5.76 & 5.75 \\
\hline Loan loss provisions (as a percentage of non-performing loans) & & & & 52.8 & 48.9 & 49.2 \\
\hline Capital adequacy ratio & 35.6 & 31.3 & 25.2 & 22 & 16.1 & 15.2 \\
\hline \multicolumn{7}{|l|}{ Memo } \\
\hline Number of banks (foreign-owned) & 23 & 25 & 24 & 25 & 24 & \\
\hline Asset share of foreign-owned banks (\%) & 75.3 & 72.7 & 75.2 & 82.7 & 81.6 & \\
\hline
\end{tabular}

Sources: BNB, EBRD, IMF, Hilbers et al. (2005).

1) Excluding housing credit.

Overall credit risk may be rising, but from a relatively low level. Given the high credit growth, lending standards may have fallen, which, together with increasing debt burdens, would trigger a rise in the credit risk. However, as yet, there is no evidence of this in the credit quality figures. The share of nonperforming loans in total loans stands at 2.2\% (see Table 2.8).

\section{Market and liquidity risk}

It is difficult to assess the interest rate risk to which the Bulgarian banking sector is exposed, but it does not appear large. Bulgarian banks rely mainly on short-term deposits (up to 3 months) to fund longer maturity loans. In recent years, banks have lengthened the maturity of loans to households and enterprises. Consequently, the share of loans with a maturity of up to one year decreased from 53\% in 1999 to $35 \%$ in 2005 . Despite the decline in interest 
rates, the share of short-term deposits in total deposits has been relatively constant, ranging between $72 \%$ and $78 \%$. The ratio of short-term loans to short-term deposits therefore sank to around $45 \%$ in mid-2005. It is difficult to assess the extent of the banking sector's exposure to the interest rate risk arising from this maturity mismatch without more detailed information on whether credit is extended with fixed or floating interest rates. In terms of profit, banks have become more dependent on interest income (see Table 2.7). As the share of income derived from non-interest sources has fallen, banks have reduced their income diversification and thereby have become somewhat more vulnerable to interest rate volatility.

Equity market risk is limited, as equity holdings are small as a percentage of total assets, and banks derive only a minor part of their income from equity trading and related activities.

The banking system's exposure to exchange rate risk is limited, mainly due to the stable CBA. Foreign currency deposits and lending are predominantly in euro. Credits and deposits in non-euro currencies account for only $3.8 \%$ of total lending and $17.8 \%$ of total deposits respectively. The ratio of lending in non-euro foreign currencies to deposits in non-euro foreign currencies is $21.1 \%$ (see Table 2.8), implying that the banking sector could be negatively affected by a depreciation of the euro against these non-euro foreign currencies.

Liquidity ratios have been declining over the last five years, but may still be considered adequate. Liquid assets (cash and securities) represent around $18 \%$ of total assets and the ratio of short-term assets (cash and securities and credit up to 3 months) to short-term deposits (up to 3 months) is around $75 \%$. Access to liquidity from the interbank market is still relatively limited, even though the size of interbank claims and interbank money market turnover have increased over the past few years. Under the CBA, the availability of reserves imposes strict limitations on the role of the $\mathrm{BNB}$ as a liquidity provider for the banking system.

\section{Shock-absorbing factors}

Relatively high profitability and a solid capitalisation are the basis for the banking sector's capacity to absorb negative shocks. Despite declining interest rate margins, the profitability of the banking sector in Bulgaria continues to be relatively high, as evidenced by the return on equity and return on assets ratios. The capital adequacy ratio has decreased over recent years, but still comfortably exceeds the minimum requirement of $12 \%$ set by the $\mathrm{BNB}$ (and that of $8 \%$ in the Basel Capital Accord). Provisions cover more than two-thirds of nonperforming loans.

Increased foreign participation in the banking sector through privatisation, has helped to boost efficiency and financial intermediation. In addition, foreign-owned banks are more likely to develop new market segments. Indeed, the growing share of household and mortgage lending may be seen as a contribution to a more diversified (and collateralized in the case of mortgage lending) loan portfolio. Moreover, foreign banks bring in their know-how, helping to establish more complete (and resilient) financial markets. Finally, the fact that a large part of foreign funding may be attributable to parent banks may reduce the risks associated with a possible reversal of capital flows.

\subsection{SUMMARY AND CONCLUSIONS}

Bulgaria's macroeconomic challenges relate to the recent pick-up in inflation, the increase in the current account deficit and the rise in private external debt. Positive fiscal outcomes have resulted in a fall in public external debt, which compensates for the rise in private external debt. Given the strong credit growth, which has been accompanied by a widening of the current account deficit, the BNB has adopted restrictive administrative and prudential measures to curb the path of credit expansion. However, with an open capital account, experience suggests that any dampening effect may be only temporary, as these measures tend to be circumvented over time. 
The financial sector is largely bank-based, private and foreign-owned, and profitable. Banks are predominantly deposit financed and have relatively high capital reserves. The change in the ownership structure has helped to enhance competition. Rapid credit growth has been associated with a substantial change in the net positions of the banking sector vis-à-vis those of the real sector, including the foreign sector. Consequently, banks' net foreign assets turned from a strongly positive to a slightly negative position. On the asset side of the balance sheet, there has been a shift from foreign assets towards domestic claims. Owing to the relatively small size of the domestic interbank market, claims on other banks are modest.

Given the rapid rise in loans, in particular to households and for housing, Bulgaria's banking sector is primarily exposed to credit risk. Its exposure to interest rate risk, however, appears to be limited, though it could become a source of credit risk if the costs associated with adverse interest rate developments are passed on to customers.

\section{ROMANIA}

\section{I MACROECONOMIC DEVELOPMENTS AND VULNERABILITIES}

\section{Development of Romania's external environment}

Romania has an increasingly open economy. The degree of openness, defined as the sum of exports and imports of goods and services as a share of GDP, was $76.5 \%$ in 2005. Romania's largest trading partner is the EU, which accounted for $64.5 \%$ of total trade in 2005 , with the euro area accounting for more than $50 \%$. Its most important partner countries are Italy, Germany, France and the United Kingdom. Other major trading partners are Turkey (7.9\% of exports) and the United States (4.1\%).

On the export side, Romania is facing increasing competition from the textile industries of Asian countries, as the share of textile products and clothing in total exports of goods has been relatively high (around 19\% in 2005). However, the higher shares of machinery and electrical equipment in total exports also indicate that Romania has recently been moving up the value-added scale. In general, the global environment is expected to remain supportive of Romania's external position, as the prospects for growth in the EU are improving and global growth is expected to remain strong.

In line with global developments, external financial conditions have been benign. Supported also by improved macroeconomic conditions and prospects for EU accession, ratings have been upgraded and spreads on euro-denominated government bonds have declined substantially over the last few years to around 50 basis points. At the same time, financial integration with the EU and the euro area has been advancing rapidly.

\section{Development of Romania's domestic}

macroeconomic environment

Output growth has been strong in the last few years but has slowed down since mid-2005. In the period from 2001 to 2003, Romania saw strong output growth, which on average exceeded 5\% annually. Economic growth reached $8.4 \%$ in 2004 due to strong agricultural output. Household consumption increased by $12.9 \%$ (particularly in the second half of the year, when the growth rate exceeded 14\%). The main reasons for this rise were (i) high real wage and pension gains, partly due to preelection hikes in the public sector; (ii) strong consumer credit growth; and (iii) the positive impact of a bumper harvest on rural incomes. Moreover, gross fixed capital formation expanded by $10.8 \%$. By contrast, net exports were strongly negative, as solid export growth at $13.9 \%$ was outpaced by an even faster import growth of $22.1 \%$. In 2005, GDP growth decelerated to less than half of what was observed the year before, reaching $4.1 \%$, owing to a slowdown in final consumption and net exports of goods and services. In addition, adverse weather conditions caused agriculture output to fall by $13.9 \%$. As a result, gross fixed 


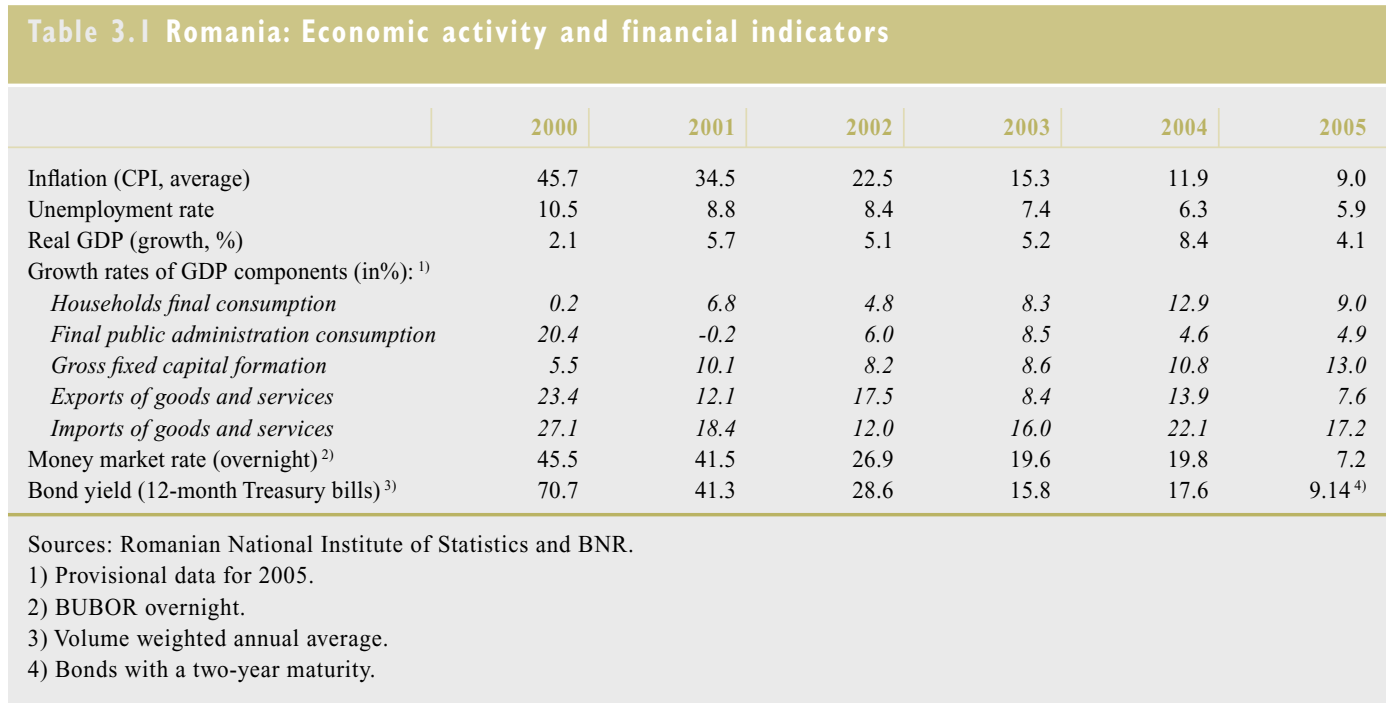

capital formation became the fastest growing component in GDP (13\% year-on-year).

After several years of rapidly falling inflation, the disinflation process has slowed down recently. Inflation, measured by $\mathrm{CPI}$, dropped from $40.7 \%$ in December 2000 to $9.3 \%$ in December 2004, despite sizeable upward adjustments in gas and electricity prices. Food prices, with a weight of over $40 \%$ in the CPI, led the decline, while services initially lagged. In 2005, the disinflation process slowed down due to the strong domestic demand fostered by high wage growth and further adjustments in administered prices, particularly in the energy sector. Consequently, year-on-year inflation was $8.6 \%$ in December 2005, and thus slightly above Banca Naţională a României’s (BNR) revised inflation target of $7.5 \% \pm 1$ percentage point. For the end of 2006, the BNR has set an inflation target of $5.0 \%$, with a \pm 1 percentage point deviation band. Fiscal and wage policies, the future dynamics of administered prices and food prices, and developments in international oil and natural gas prices all constitute a major risk to the inflation outlook.

Before August 2005, monetary policy operated under an eclectic framework that combined a monetary targeting strategy with a managed floating exchange rate regime. Under this framework, the BNR attempted to reconcile the objective of disinflation with that of achieving a sustainable external position.

In August 2005, the BNR officially adopted a formal inflation targeting strategy. Under this new monetary framework, annual inflation targets are set jointly by the BNR and the government two years ahead in terms of headline CPI.

The BNR faces the task of fighting inflation in a context in which large capital inflows may lead to an unsustainable level of exchange rate appreciation. In this context, it has increased the minimum reserve requirements for foreignexchange-denominated liabilities of credit institutions, adopted a prudential limit of $300 \%$ of own funds for credit institutions' exposure to unhedged borrowers in September 2005, and, in early February 2006, raised its monetary policy rate from $7.5 \%$ to $8.5 \%$. This dilemma has to some extent been alleviated by the global unwinding of accommodative monetary policies.

The role of the interest rate in transmitting monetary policy impulses has increased over time. The short-term interest rate has gradually assumed a quasi-operational role, allowing the central bank to influence the economy and 
Table 3.2 Romania: Fiscal indicators (ESA)

\begin{tabular}{|c|c|c|c|c|c|c|c|}
\hline \multicolumn{8}{|l|}{$(\%$ of GDP) } \\
\hline & 2000 & 2001 & 2002 & 2003 & 2004 & $2005(f)$ & 2006(f) \\
\hline Overall balance & -3.8 & -3.5 & -2.0 & -2.0 & -1.4 & -0.9 & -0.7 \\
\hline Primary balance & -0.7 & -0.3 & 0.2 & -0.4 & -0.2 & 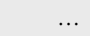 & \\
\hline General government gross debt & 22.7 & 23.2 & 23.3 & 21.3 & 18.5 & 16.2 & 15.6 \\
\hline
\end{tabular}

Source: Eurostat.

Note: $(\mathrm{f})=$ forecast.

inflationary expectations more efficiently. Nominal interest rates declined until mid-2003 (the interest rate on 12-month Treasury bills dropped from $41.3 \%$ in 2001 to $15.8 \%$ in 2003), when the BNR raised the monetary policy interest rate to combat the weakening in the balance of payments, the rapid credit growth and the slowdown in disinflation. After mid2004, the BNR lowered its interest rates again to forestall capital inflows. The interest rates applied by banks to non-government clients also decreased - for new short-term loans from about $25 \%$ in 2004 to around $14 \%$ in December 2005 , and for new short-term deposits from $15 \%$ to around $5 \%$ over the same period.

In terms of exchange rate developments, a longstanding nominal depreciation path has turned into appreciation pressures. Since the beginning of 2000, the BNR has gradually reduced the depreciation rate, in line with its inflation target, and at the same time has allowed substantial short-term variability in the exchange rate. The rate of depreciation of the leu against the euro therefore slowed down from $30.1 \%$ in 2001 to $8.2 \%$ in 2004 . As a result of the increase in capital inflows, the leu appreciated considerably against the euro from the last quarter of 2004 to the end of 2005. By then, appreciation pressures started to decline in the light of the reduction in BNR and interbank interest rates, but have again picked up moderately since early 2006. The BNR expects appreciation pressures to remain manageable due to less volatile capital inflows, a widening of the trade deficit and an increase in payments on external private debt. However, they might increase again, due to foreigners being granted access to money market instruments, a reduction in the country risk with Romania's entry into the EU and strong remittances flows from Romanian citizens working abroad.

Fiscal policy provided support for macroeconomic stabilisation after 2000, but now faces several challenges. The general government deficit gradually declined from $3.8 \%$ of GDP in 2000 to an estimated $0.9 \%$ of GDP in 2005 (see Table 3.2), reflecting savings on interest payments, a reduction in expenditures and improved tax collections. For 2006, a deficit of $0.5 \%$ of GDP has been budgeted. Fiscal challenges include the lower revenues resulting from the implementation of tax reforms, the rising expenditures generated by the muchneeded investment in the infrastructure and the indexation of pensions based on CPI developments.

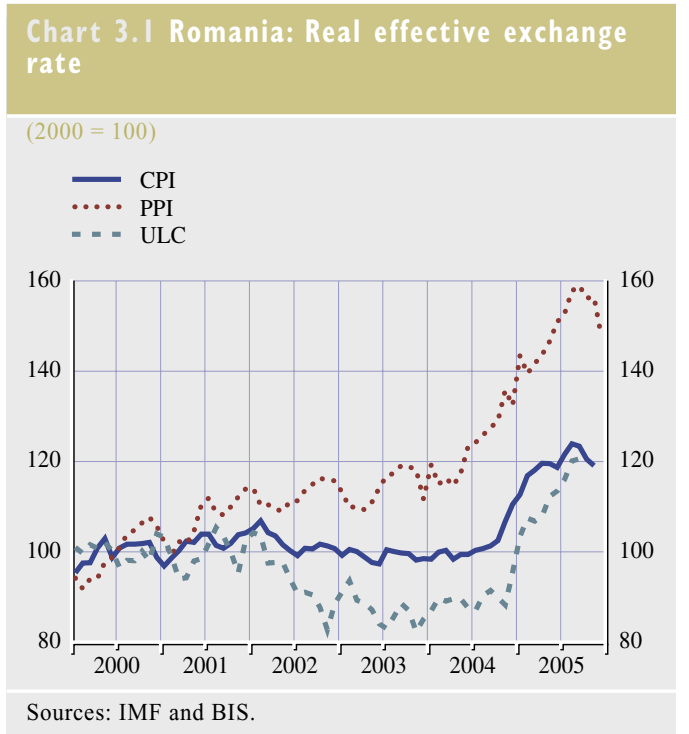




\begin{tabular}{|c|c|c|c|c|c|c|}
\hline & 2000 & 2001 & 2002 & 2003 & 2004 & 2005 \\
\hline Current account (in \% of GDP) & -3.7 & -5.5 & -3.3 & -5.8 & -8.4 & -8.7 \\
\hline FDI (in $\%$ of GDP) & 2.9 & 2.9 & 2.5 & 3.6 & 8.4 & 6.6 \\
\hline International reserves (months of imports) & 2.9 & 3.6 & 4.2 & 4.1 & 5.2 & 6.4 \\
\hline External debt (in \% of GDP) & 29.7 & 32.7 & 33.4 & 33.9 & 36.0 & 38.5 \\
\hline
\end{tabular}

The REER indices suggest that Romania's competitiveness remained more or less unchanged from 2000 to mid-2004, but that it has deteriorated recently. Until mid-2004, unchanged competitiveness was assured by the nominal depreciation of the leu. Since mid2004, however, the nominal appreciation of the leu, together with declining productivity gains and strong wage growth (in December 2005, net nominal public sector wages rose by $25.4 \%$ year-on-year), has been weakening competitiveness.

FDI has increased substantially in recent years in line with the macroeconomic stabilisation. Moreover, further FDI flows to export-oriented industries may be prompted by the progress of Romania towards EU accession. Export growth may therefore be enhanced by long-term capital investment and foreign demand growth but it could be negatively impacted by the rising real unit labour costs and the exchange rate appreciation. At the same time, imports can be expected to increase given the real appreciation of the domestic currency and strong consumption, further deteriorating the current account.

The liberalisation of the capital account started in 1991 and has been a gradual process. The liberalization of medium and long-term capital inflows was completed in 1999. With nominal convergence progressing, all other flows have been liberalized since then, with the exception of inward and outward investment in money market instruments (expected in September 2006). This process, along with decreases in country risk and relatively low interest rates abroad, has improved external financing conditions.
Foreign capital inflows and central bank intervention have led to an increase in international reserves, which by end-2005 stood at a level sufficient to finance approximately six months of imports $(21.2 \%$ of annual GDP). Owing to the increasing borrowing abroad, external debt is continuing to rise and currently amounts to $38.5 \%$ of GDP, but this figure is still low in comparison with other emerging market economies.

\subsection{THE ROMANIAN BANIING SECTOR}

\section{STRUCTURE AND DEVELOPMENTS}

\section{A short history of the Romanian banking sector} Until 1998, the Romanian commercial banking system was overwhelmingly state-owned. Credit institutions granted loans to a largely nonrestructured state-owned real sector, partly financed by direct credit from the BNR. When in 1997 macroeconomic policies were tightened, banking supervision was strengthened and direct credits were discontinued, several credit institutions faced solvency and liquidity problems due to a large number of bad loans that had accumulated in previous periods. Consequently, a number of banks failed between 1997 and 1999, including Bancorex, the country's largest bank, in $1999 .{ }^{9}$ In 2000 , the country's largest investment fund failed and several other banks went bankrupt in a second wave of turbulence that was triggered by severe infringements of banking discipline and non-

9 As the failure of Bancorex threatened the stability of the entire banking system, the bank was restructured and taken over by the state-owned Banca Comercială Română (BCR), which then became the largest bank. In total, the costs of the various recapitalisation and public support schemes for the institutions in distress amounted to about $10 \%$ of GDP. 
Table 3.4 The structure of the Romanian banking sector

\begin{tabular}{|c|c|c|c|c|c|c|c|}
\hline & 1999 & 2000 & 2001 & 2002 & 2003 & 2004 & 2005 \\
\hline EBRD index of banking sector reform & 2.7 & 2.7 & 2.7 & 2.7 & 2.7 & 3.0 & \\
\hline Number of banks (foreign-owned) ${ }^{1)}$ & $34(19)$ & $33(21)$ & $33(24)$ & $31(24)$ & $30(21)$ & $32(23)$ & $33(24)$ \\
\hline Number of banks per 100,000 inhabitants & 0.18 & 0.18 & 0.19 & 0.18 & 0.18 & 0.18 & 0.19 \\
\hline Asset share of private banks (\%) & 53.2 & 53.9 & 58.2 & 59.6 & 62.5 & 93.1 & 94.0 \\
\hline Asset share of foreign banks $(\%)^{2)}$ & 47.5 & 50.9 & 55.2 & 56.4 & 58.2 & 62.1 & 62.2 \\
\hline Asset share of five largest banks (\%) & 66.7 & 65.5 & 66.1 & 62.9 & 61.7 & 59.8 & 59.6 \\
\hline Market share of five largest banks in total assets & 66.7 & 65.5 & 66.1 & 62.9 & 61.7 & 59.2 & 58.8 \\
\hline Herfindahl-Hirschmann index & 1,296 & 1,375 & 1,427 & 1,381 & 1,264 & 1,120 & 1,124 \\
\hline Interest rate spread & 20.7 & 20.6 & 17.2 & 16.1 & 14.5 & 13.7 & $\ldots$ \\
\hline
\end{tabular}

observance of prudential principles in managing assets and liabilities.

Privatisation - mainly through foreign investors - led to a considerable decrease in state ownership. In December 2005, Austria's Erste Bank der oesterreichischen Sparkassen AG acquired $61.9 \%{ }^{10}$ of Banca Comercială Română (BCR) - the country's largest single privatisation transaction and also the largest amount paid so far for a bank in Central and Eastern Europe leaving the savings bank Casa de Economii şi Consemnatiuni (CEC) and Eximbank (Banca de Export-Import a României) as the only two banks with majority state-ownership. The sale of the majority stake of CEC is ongoing. While structural changes in the banking system have been substantial, the EBRD index of the banking sector reform indicates that there is still scope for further improvement.

\section{The current structure of the banking system}

The Romanian banking system is mainly private and foreign-owned. The share of foreign-owned banks in total assets (including foreign bank branches) increased considerably between 1998 and 2004 , from $20 \%$ to $62.1 \%$. Including the $\mathrm{BCR}$, end-2005 figures show majority foreignowned banks to account for $87.9 \%$ of total sector assets. ${ }^{11}$

Bank density has remained more or less unchanged and stands at a level lower than in the euro area. By contrast, the number of bank branches has been rising and, in 2004, the number of bank branches per credit institution was almost five times higher than that in the euro area. Concentration in the Romanian banking sector, as measured by the share of the five largest institutions in total assets, has been falling but is still higher than in the euro area. This can be substantiated by the HerfindahlHirschman index. Falling concentration and the growing share of foreign-owned banks ${ }^{12}$ can be perceived as signs of improving competition.

\section{The structure of assets and liabilities}

The level of banking intermediation in Romania is the lowest among the four countries under review and considerably lower than in the euro area and the NMS-8. This can be partly explained by the difference in per capita income. Moreover, capital account liberalisation and strong financial inflows provide domestic enterprises with access to ample financial sources outside the domestic banking system. Finally, the recently introduced prudential measures aimed at curbing credit growth might have pushed a larger share of the credit demand towards nonbank financial institutions (e.g. leasing companies and non-bank consumer credit companies).

10 The share was comprised of a joint stake of $25 \%$ of the EBRD and the IFC, and $36.9 \%$ of the Authority of State Asset Recovery.

11 It should be noted that since the property transfer between the BCR and Erste Bank was not completed by the end of 2005, the official figure for the share of foreign-owned banks in total banking sector assets is $62.2 \%$ as reported in table 3.4 .

12 For empirical evidence on the relationship between foreign bank presence and competitiveness indicators see Claessens and Laeven (2004). 


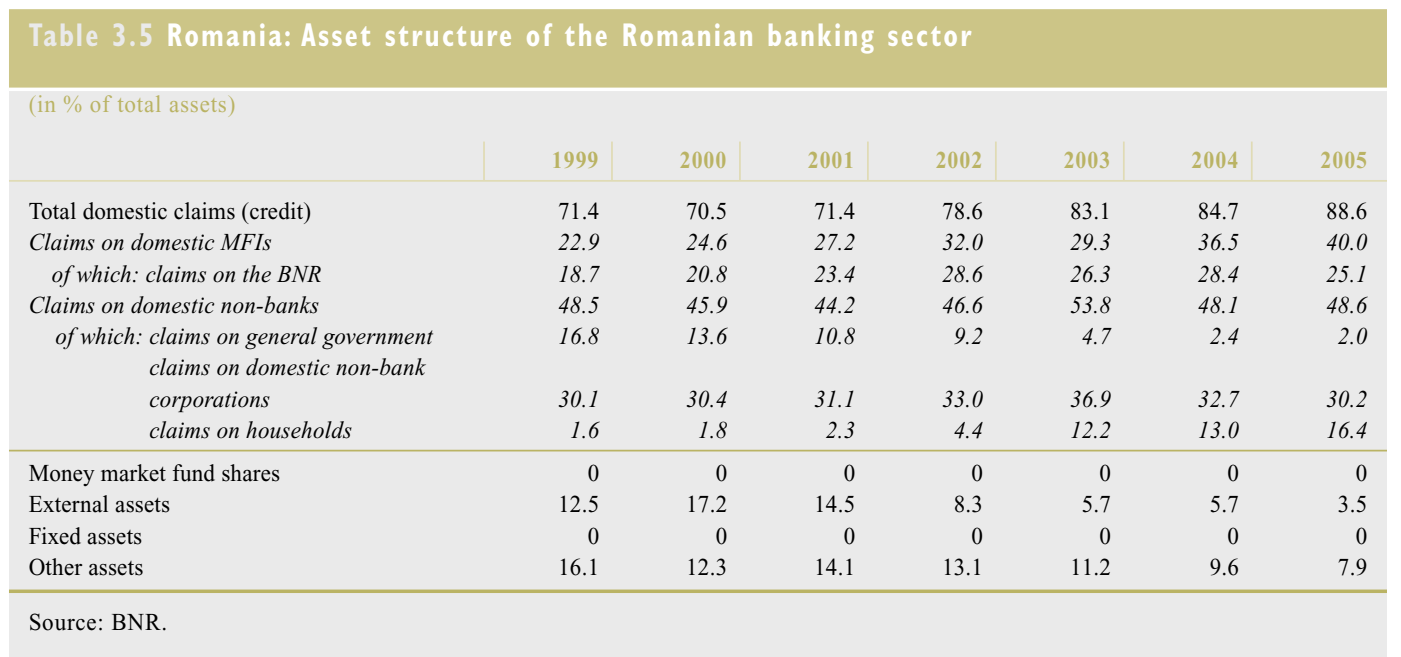

The restructuring and consolidation processes have changed the asset structure of the banking sector, with banks returning to core banking activities. The share of domestic claims in total assets increased from $71.4 \%$ in 1999 to $88.6 \%$ in 2005 (see Table 3.5), driven by (i) strong growth in household and mortgage lending, albeit from low levels, and (ii) a doubling in claims on domestic monetary and financial institutions (MFIs), with claims on the BNR constituting the lion's share (almost 80\%). Claims on the BNR reflect its activities to drain excess liquidity from the system provided by foreign capital inflows and foreign exchange interventions (which lasted until October 2005). Among the latest moves of the BNR was the raise of the required reserve ratio on foreign currency deposits to $40 \%$ from $35 \%$ in February 2006.

Claims on non-bank corporations still account for a large share of total banking sector assets (30.2\% in 2005). The sectoral decomposition of bank credit mirrors the structure of the Romanian economy, with industry and services accounting for the largest shares. Another noteworthy development is the decrease in the share of external assets in total assets. This, in turn, coincides with the increase in total domestic claims, indicating that banks first liquidated part of their foreign assets to fund the expansion of domestic credit. By contrast, lending to general government has decreased considerably, reflecting, among other things, the decline in budget deficits and the relatively low level of public debt.

Deposits of households and non-bank corporations are the most important source of financing for commercial banks $(57.5 \%$, see Table 3.6), whereas deposits of MFIs account for less than $3 \%$ of total liabilities. This is in contrast to the euro area, where deposits of MFIs make up for about $20 \%$ of total funding, indicating that interbank market activities in Romania are fairly limited. Debt securities, which are used extensively by euro area banks as a source of funds, do not play any role either, suggesting that the domestic bond market is still underdeveloped and that ample liquidity is available from other sources, i.e. in the form of foreign borrowing, mostly from parent banks. Foreign borrowing has risen considerably in recent years, from $5.7 \%$ of total liabilities in 2000 to $20.9 \%$ in 2005 .

Although net claims on domestic households and non-bank corporations are negative $(-10.9 \%$ in 2005), they have increased in the past few years. The turning point came in 2001 when the share of claims in total assets started to increase and the share of deposits in total liabilities began to decrease. By contrast, and in parallel, the net position against the general government fell from $13.8 \%$ in 1999 to $-1.5 \%$ in 2005 , largely owing to the reduction in credit 


\section{Table 3.6 Romania: Liability structure of the Romanian banking sector}

\begin{tabular}{|lrrrrr|r|}
\hline (in \% of total liabilities) & & & & & \\
& & & & & 2004 \\
& 2000 & 2001 & 2002 & 2003 & 6805 \\
\hline Total deposits of domestics (incl. liabilities to MFIs) & 76.3 & 74.4 & 75.1 & 71.4 & 68.0 & 63.6 \\
Deposits of MFIs & 4.7 & 4.0 & 3.4 & 3.2 & 3.0 & 2.6 \\
Deposits of domestic non-banks & 71.6 & 70.4 & 71.7 & 68.2 & 65.0 & 61.0 \\
$\quad$ of which: deposits of general government & 3.0 & 3.7 & 3.1 & 3.0 & 2.6 & 3.5 \\
$\quad$ deposits of households \& non-bank corporations & 68.5 & 66.7 & 68.6 & 65.2 & 62.4 & 57.5 \\
\hline Money market fund shares & 0 & 0 & 0 & 0 & 0 & 0 \\
Debt securities issued & 0 & 0 & 0 & 0 & 0 & 0 \\
Capital and reserves & 10.8 & 14.4 & 13.5 & 13.1 & 11.8 & 12.2 \\
External liabilities & 5.7 & 5.9 & 7.0 & 11.7 & 15.8 & 20.9 \\
Remaining liabilities & 7.3 & 5.3 & 4.4 & 4.0 & 4.5 & 3.3 \\
\hline
\end{tabular}

Source: BNR.

outstanding to the government, while net claims on domestic MFIs rose sixfold between 1998 and 2005, mainly as a result of soaring deposits and commercial bank reserves held at the BNR. Finally, owing to the sharp increase in foreign borrowing and banks' sales of foreign assets, Romania's net external asset position has deteriorated significantly, turning from positive in 1999 to negative in 2003 and reaching $-17.4 \%$ of total assets in 2005 .

Comparing the net position of Romanian banks with that of euro area banks reveals differences in their balance sheet structure. In Romania, banks rely mostly on domestic deposits and borrowing from abroad to finance the growing net claims on domestic households and non- bank corporations. Conversely, the euro area banks' sources of funds are more diversified, as they are benefiting from the developed bond and interbank markets.

The profitability of the banking system

The Romanian banking sector has been characterised by a relatively high level of profitability. Rising net interest income has been one of the main drivers of profitability in recent years, mainly reflecting the rapid growth in domestic credit. This marks a substantial change from the late 1990s, when net noninterest income constituted the bulk of revenues, due to the arbitrage opportunities opened up to banks by the imperfections in various segments of the financial and exchange markets. A

Table 3.7 Profitability of the Romanian banking sector

\begin{tabular}{|c|c|c|c|c|c|c|c|}
\hline & 1999 & 2000 & 2001 & 2002 & 2003 & 2004 & 2005 \\
\hline Net interest income in $\%$ of average assets & -1.6 & 0.0 & 2.6 & 3.4 & 4.7 & 4.9 & 3.6 \\
\hline Net non-interest income in $\%$ of average assets & 22.7 & 12.4 & 10.4 & 7.4 & 5.9 & 5.1 & 4.6 \\
\hline Operating income in $\%$ of average assets & 21.1 & 12.4 & 13.0 & 10.9 & 10.5 & 10.0 & 8.2 \\
\hline Ratio of net interest income in operating income & -7.5 & 0.4 & 20.0 & 31.7 & 44.2 & 49.4 & 43.8 \\
\hline Operating costs in $\%$ of average assets & 12.4 & 7.8 & 7.5 & 6.7 & 6.9 & 6.2 & 5.5 \\
\hline Personnel costs in $\%$ of operating costs & 51.3 & 44.9 & 41.7 & 43.9 & 42.8 & 41.9 & 41.5 \\
\hline Cost-to-income ratio & 58.5 & 62.4 & 57.8 & 62.0 & 65.1 & 61.6 & 66.7 \\
\hline $\begin{array}{l}\text { Net costs of loan loss provisioning } \\
\text { in } \% \text { of average assets }\end{array}$ & 8.0 & 2.0 & 0.6 & 0.2 & 0.6 & 0.7 & 0.5 \\
\hline $\begin{array}{l}\text { Net costs of loan loss provisioning } \\
\text { in } \% \text { of operating income }\end{array}$ & 37.9 & 16.1 & 4.7 & 2.0 & 5.5 & 7.3 & 6.0 \\
\hline Return on assets & -1.5 & 1.5 & 3.1 & 2.6 & 2.2 & 2.0 & 1.7 \\
\hline Return on equity & -15.3 & 12.5 & 21.8 & 18.3 & 15.6 & 15.6 & 12.9 \\
\hline
\end{tabular}

Source: OeNB and BNR.

Note: $(\mathrm{e})=$ estimate. 
substantial decline in the net costs of loan loss provisioning has been another important factor supporting profitability, but, more recently, these have increased again, which partly explains the most recent drop in profitability, as measured by return on equity and return on assets.

Romanian banks have succeeded in improving cost efficiency, mostly through substantial cuts in personnel costs, which - as a percentage of total operating costs - currently stand at a lower level than in the euro area. Further progress in the cost-cutting process might help to preserve profitability, particularly in the light of the deterioration in some sources of income. But, given that personnel costs are already relatively low as a percentage of total operating costs, further cost cuts will most likely come from other areas.

While the outlook for profitability remains positive, there are a number of challenges. First, operating income has been declining, and this trend might continue in the light of decreasing interest rate margins, increasing competition and a falling share of domestic deposits, which are considered to be a relatively cheap source of financing. Second, further cuts in operating costs might be more difficult to achieve, as basic restructuring measures have already been implemented. Last, but not least, any deterioration in credit quality would lead to additional provisioning costs.

\section{RISKS AND SHOCK-ABSORBING CAPACITIES}

\section{Credit risk}

The Romanian banking system is primarily exposed to credit risk. As the degree of financial intermediation continues to rise rapidly and bank assets increasingly consist of loans, credit risk is likely to remain of concern in the near future.

Ongoing financial deepening in the Romanian banking sector is translating into rapid private sector credit growth, with household credit growing much faster than corporate credit, albeit from a much lower level (see Table 3.8). Real domestic credit in Romania grew at an average of $18.4 \%$ per annum between 2000 and 2005 , up from the average 5\% growth rate between 1995 and 1999. However, while credit to the private sector has been the true driver of total credit growth, lending to the public sector has actually been decreasing since 2002. Real claims on the private sector grew at an average of $18.3 \%$ per annum in the period 2000-04, supported by lower interest rates, as well as rising household incomes and real estate prices, which made household credit the most dynamic category. Overall, the share of household credit in total private sector credit grew from $5.7 \%$ in 2000 to $35.2 \%$ in December 2005. Within household credit, loans for real estate purchase advanced rapidly, growing at an average annual rate of $98.9 \%$ in real terms; thus, the share of mortgage loans in total private sector credit rose from $1.7 \%$ to $14.9 \%$ between 2000 and October 2005.

Despite these developments, credit quality has been improving since 2003. Non-performing loans (unadjusted exposure of doubtful and loss loans and interests over total classified loans and interests) and doubtful and past due claims (over total net assets) have decreased, to 2.6 and 0.1 in 2005 , respectively. These figures should be interpreted with some caution however, particularly because they benefited from the favourable economic conditions and are therefore subject to change in the event of a cyclical downturn. Moreover, the nonperforming loan ratio tends to be biased downward during times of strong credit growth, when the ratio's denominator is rapidly increasing. Finally, rapid credit growth can be associated with an overstretching of risk management capabilities (and consequently less careful analysis), as well as with the financing of less creditworthy clients and less profitable projects. In particular, this may be the case when bank managers are focusing on volumes in a bid to win market share. 
Table 3.8 Romania: Selected banking sector stability indicators

\begin{tabular}{|c|c|c|c|c|c|c|}
\hline & 2000 & 2001 & 2002 & 2003 & 2004 & 2005 \\
\hline \multicolumn{7}{|l|}{ Risks } \\
\hline \multicolumn{7}{|l|}{ Credit risk } \\
\hline Domestic credit growth (\%, y-o-y) & 11.4 & 26.9 & 39.9 & 50.4 & 21.2 & 49.7 \\
\hline Real domestic credit growth $(\%, y-0-y)^{1)}$ & -20.8 & -2.6 & 18.8 & 31.8 & 10.9 & 37.8 \\
\hline Growth in real claims on the private sector $(\%, y-0-y)$ & -10.2 & 16.5 & 14.2 & 23.7 & 18.7 & \\
\hline Growth in real claims on non-bank financial institutions ( $\%, y-0-y)$ & -0.6 & 29.6 & 109.5 & 181.0 & 39.8 & \\
\hline Real credit growth to households $(\%, y-0-y)^{1)}$ & 3.2 & 44.0 & 122.0 & 214.6 & 44.8 & 65.7 \\
\hline Real growth in loans for real estate purchase $(\%, y-0-y)$ & & 91.1 & 68.1 & 150.9 & 85.3 & \\
\hline Non-performing loans ( $\%$ of total loans) & 3.8 & 2.5 & 1.1 & 3.4 & 2.9 & 2.6 \\
\hline Doubtful and past-due claims (in $\%$ of total net assets) & 0.3 & 0.3 & 0.2 & 0.2 & 0.2 & 0.1 \\
\hline Foreign currency credit ( $\%$ of total private sector credit) & 59.5 & 59.8 & 62.9 & 55.4 & 60.8 & 57.9 \\
\hline Foreign currency deposits ( $\%$ of total deposits by non-banks) & 47.0 & 49.3 & 44.7 & 42.5 & 41.2 & 34.5 \\
\hline Foreign liabilities real growth $(\%, y-0-y)$ & -16.2 & 21.7 & 36.7 & 88.2 & 83.4 & 73.2 \\
\hline Foreign liabilities ( $\%$ of total liabilities) & 5.7 & 5.9 & 7.0 & 11.7 & 15.8 & 20.9 \\
\hline \multicolumn{7}{|l|}{ Market risk } \\
\hline \multicolumn{7}{|l|}{ Interest rate risk } \\
\hline Net interest income in \% of average assets & 0.0 & 2.6 & 3.4 & 4.7 & 4.9 & 3.6 \\
\hline Net non-interest income in $\%$ of average assets & 12.4 & 10.4 & 7.4 & 5.9 & 5.1 & 4.6 \\
\hline Interest rate spread & 20.6 & 17.2 & 16.1 & 14.5 & 13.7 & \\
\hline Ratio of short-term loans to total loans & 50.4 & 53.7 & 53.4 & 45.2 & 40.6 & 35.9 \\
\hline \multicolumn{7}{|l|}{ Forex risk } \\
\hline Open FX position in $\%$ of total balance sheet assets & 0.8 & 0.6 & 0.7 & 0.5 & 0.1 & 0.1 \\
\hline \multicolumn{7}{|l|}{ Liquidity risk } \\
\hline Ratio of liquid assets to total assets & 52.4 & 52.4 & 50.4 & 39.2 & 36.4 & 31.4 \\
\hline Ratio of loans to deposits & 44.9 & 46.2 & 50.0 & 70.7 & 70.1 & 76.0 \\
\hline Ratio of liquid assets to short-term liabilities & $\ldots$ & 116.2 & 118.5 & 207.2 & 197.0 & 239.8 \\
\hline \multicolumn{7}{|l|}{ Shock-absorbing factors } \\
\hline Loan loss reserves and provisions ( $\%$ of non-performing loans) & 85.7 & 78.2 & 53.7 & 59.4 & 68.9 & 55.1 \\
\hline Capital adequacy ratio & 23.8 & 28.8 & 25 & 21.1 & 20.6 & 20.2 \\
\hline \multicolumn{7}{|l|}{ Memo } \\
\hline Number of banks (foreign-owned) & $33(21)$ & $33(24)$ & $31(24)$ & $30(21)$ & $32(23)$ & $33(24)$ \\
\hline Asset share of foreign-owned banks (in \%) ${ }^{2)}$ & 43.1 & 47.3 & 49.0 & 50.5 & 53.6 & 54.7 \\
\hline
\end{tabular}

Sources: BNR, EBRD, IMF and ECB calculations.

1) Deflated by CPI Dec./Dec.

2) Asset share of foreign-owned banks does not include foreign banks' branches.

Inspections by the BNR have identified - the delayed publicity of the collateral.

deficiencies in credit risk management, such

as:

- the misapplication of the loan classification methodology;

- the repeated extension of credit lines, and debt rescheduling;

- the large exposure to a small number of customers;

- the granting of preferential loans to debtors in special relations with the bank;
Banks are potentially exposed to significant credit risk through indirect foreign exchange risk. In $2005,54 \%$ of private sector credit was foreign-exchange-denominated. Moreover, a large proportion of this credit is extended to the non-tradables sector. Stress tests indicate that "the main source of risk to banks is the credit risk materialising from exchange rate and interest rate exposures of the corporate sector". ${ }^{13}$ Owing to low debt levels, credit risk related to household lending is still limited, but is growing rapidly.

13 See IMF (2003) p. 15. 


\section{Market and liquidity risk}

Interest rate risk is low, but has been increasing, both in terms of income and the balance sheet. This means that the income of banks is becoming more sensitive to interest rate developments. ${ }^{14}$ Furthermore, the sensitivity of balance sheets to interest rates has been rising due to increasing loan maturities, which is indicated by the shrinking share of short-term loans in total loans. Whereas longer maturity loans have so far tended to have variable interest rates, which attenuate the interest rate risk, this is likely to change as mortgage lending takes off. ${ }^{15}$

Equity price risk is limited, as banks do not have substantial holdings of shares and participations, and derive only a negligible part of their income from stock trading activities.

Romanian banks are exposed to some direct foreign exchange rate risk, which is reflected in a (small) short position on their balance sheet and in the fact that a sizeable part of their income is derived from foreign exchange arbitrage. Domestic credit denominated in foreign currencies grew, on average, by $49 \%$ per annum between 2000 and 2005, and at the end of 2005 , it accounted for $54 \%$ of total loans, which already reflects the BNR's measures to limit its growth. This high share is attributable to the lower interest paid on foreign currency credit $^{16}$. Conversely, foreign currency deposits have been decreasing as a percentage of total deposits since 2001, due to increased confidence in the leu and the appreciation pressures it has been facing vis-à-vis the euro. In the face of rapid credit expansion, this has resulted in a funding shortage which has been compensated by foreign borrowing. In fact, growth in foreign liabilities has been generally accelerating since the start of the decade, doubling in 2004. Stress tests by the BNR, however, indicate that banks' exposure to exchange rate shocks is minimal.

Liquidity risk has been decreasing, as the system as a whole is highly liquid. The ratio of liquid assets to total assets has remained relatively constant, due, among other things, to sizeable deposits at the central bank originating from its sterilisation activity. The ratio of shortterm assets to short-term liabilities has increased together with the ratio of loans to deposits. Liquidity is high by international standards, because most loans have a short maturity and deposits with the central bank are considered highly liquid. Stress tests by both the IMF and the BNR find liquidity risk to be small, indicating that most institutions would be able to withstand large deposit withdrawals. The contagion risk from the interbank market is negligible, as most interbank assets and liabilities are held at the BNR.

\section{Shock-absorbing factors}

A reduction in spreads, owing to increased banking competition, fast credit growth, and macroeconomic stability, has recently led to a decline in the profitability of Romanian banks. The return on assets decreased from $3.1 \%$ at the end of 2001 to $1.7 \%$ at the end of 2005 , and the return on equity decreased from $21.8 \%$ to $12.9 \%$ over the same period (see Table 3.7). Further declines in spreads triggered by continued nominal convergence and incoming capital flows for example, could have a further dampening impact on banks' profitability, and may thus increase their appetite for risk.

Privatisation and recapitalisation efforts, as well as increasingly higher minimum capital requirements, have led to a well capitalised and sound banking system. ${ }^{17}$ The capital adequacy ratio, which stood at $28.8 \%$ in 2001 (partly as a result of enhanced risk aversion towards lending

14 Stress tests by the BNR conducted in June 2005 indicate that banks' balance sheets are resilient to interest rate shocks, even though the sensitivity of balance sheets to interest rates has been rising

15 The maturity structure of claims on households and on enterprises is rather different, as the largest part of claims on the latter constitutes short-term credit, whereas claims on households are more of a medium to long-term nature.

16 In October 2005, the average interest rate applied by credit institutions on new loans in leu for individuals and legal entities was $15.6 \%$ and $14.2 \%$ per annum respectively, in comparison with $9.2 \%$ and $5.9 \%$ for new loans in euro and $9.4 \%$ and $6.0 \%$ for new loans in US dollar.

175 In its Financial System Stability Assessment (2003), the IMF described the Romanian banking sector as well capitalised liquid and generally well supervised. 
in the aftermath of the banking crisis), has fallen (to $20.2 \%$ in December 2005), but is still well above the minimum requirement of $12 \%$. At the same time, loan loss reserves and provisions (as percentage of non-performing loans) have decreased from $85.7 \%$ in 2000 to $68.9 \%$ in 2004 .

The increase in foreign ownership can be said to contribute to the resilience of the banking system, as it helps to enhance credit quality, for example, by providing know-how for improved risk assessment and credit management. Evidence of this can already be seen in the low incidence of bad loans despite the rapid credit expansion. Moreover, the presence of foreign banks may reduce the likelihood of sudden capital outflows due to the strategic nature of their investment in the country and region as a whole. However, the extent to which parent banks will support subsidiaries in practice also depends on the internal risk and profitability assessment of the parent bank.

The rapid growth of private sector credit could create debt-servicing problems over the long term. However, it is not doing so at the moment as indebtedness is still relatively low. Nevertheless, as households and the corporate sector have less assets (deposits) than liabilities (loans) in foreign currency, a depreciation of the leu or an increase in foreign interest rates could increase the debt and debt service burden.

\subsection{SUMMARY AND CONCLUSIONS}

The main challenge for the Romanian authorities is to keep disinflation on track, as domestic demand (fostered partly by strong credit growth) has been expanding rapidly, wage pressures have been increasing, adjustments in administered prices have been ongoing and energy prices have been persistently high. Formally operating under an inflation targeting regime since August 2005, monetary policy faces the issue of tightening monetary conditions within the constraints posed by the need to prevent an unsustainable exchange rate appreciation stemming from large and volatile capital inflows. Fiscal consolidation therefore remains key to supporting macroeconomic stabilisation. To minimise external vulnerabilities, the main policy challenge is to reduce the current account deficit - albeit largely financed by FDI inflows - that has resulted from strong domestic demand, rising real unit labour costs and appreciation pressures on the leu.

Banking sector development in Romania has been characterised by fast private credit growth, in particular to households (e.g. consumer lending, mortgages). However, expressed as a share of GDP, intermediation is still low. Moreover, the Romanian banking sector is generally composed of well capitalised, profitable and mostly foreign-owned banks.

Credit risk remains the main risk to financial stability in Romania. Private credit growth has been driven by improved consumer confidence, high economic growth and macroeconomic stabilisation. As a substantial share of lending is denominated in foreign currencies, endborrowers face significant foreign exchange rate risk, which could transform into a higher credit risk for banks. Banca Naţională a României (BNR) has taken restrictive measures to limit credit growth, in particular foreign currency borrowing, which has been partly induced by spreads between domestic and foreign interest rates. To date, there have been no signs of a deterioration in credit quality. Interest rate risk is also increasing, but is still at a low level.

\section{CROATIA \\ 4.I MACROECONOMIC DEVELOPMENTS AND VULNERABILITIES}

Development of Croatia's external environment: Croatia has a highly open economy, with the EU as its main trading partner. Since 2000, the sum of exports and imports of goods and services has increased from close to $100 \%$ of 
Chart 4.I Croatia: Development of export shares of selected countries in 35 countries

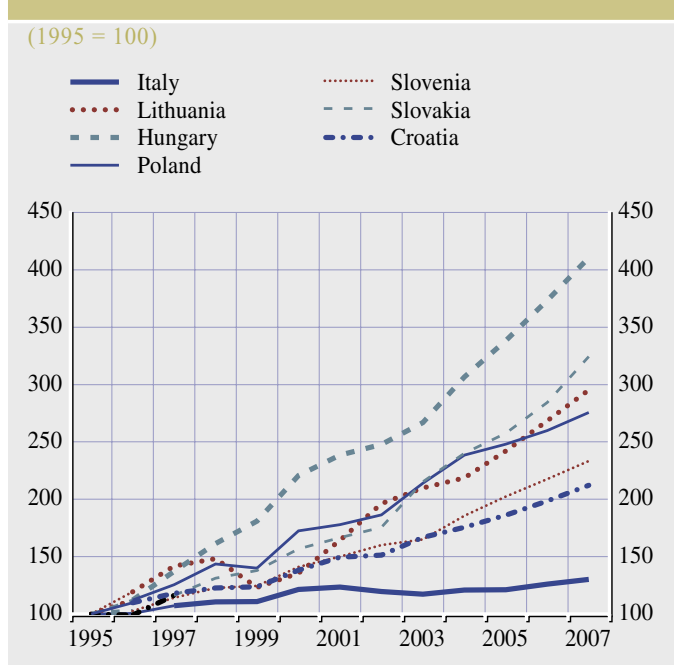

Sources: European Commission and AMECO. Note: Data for 2006 and 2007 are forecasts.

GDP to about $110 \%$, with the share of the EU and the euro area constituting almost $70 \%$ and $50 \%$ respectively.

Croatia's external position is characterised by a substantial merchandise trade deficit. This partly reflects the fact that tourism services constitute a key export item, but is also attributable to the strong import demand arising from households' optimistic income growth expectations. Moreover, as an oil importing country, Croatia is dependent on oil market developments. Finally, Croatia's trade deficit partly stems from the need to foster the accumulation and modernisation of the country's capital stock.

On the export side, Croatia has been relatively slow in upgrading its export structure. Ships, textile products, minerals, basic materials and manufactured goods increasingly commoditised on the global markets still feature prominently among its exported goods. Tourism is a highly competitive industry. Croatia's pattern of export specialisation therefore makes it vulnerable to adverse shocks arising from global competition.

\section{Chart 4.2 Croatia: JPMorgan Euro EMBIG Government Spreads}

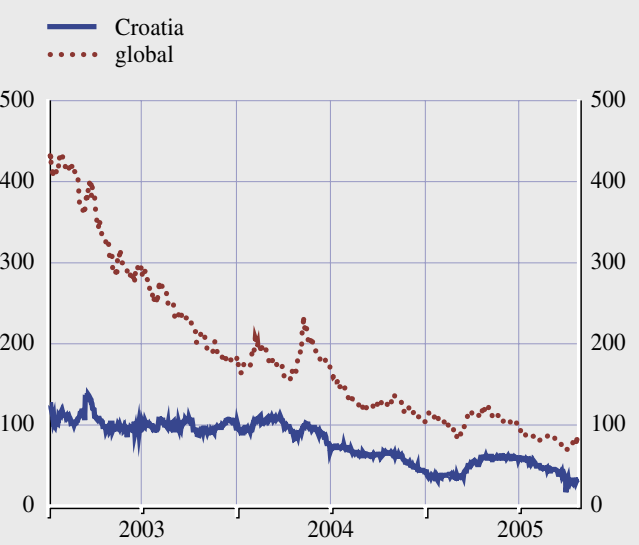

Source: Bloomberg.

In the long term, a rise in competitiveness will be important for external stability. There is room for improvement, as wage costs are relatively high compared with those of the other countries in the region and high value-added goods and knowledge intensive products constitute only a low proportion of exports. There are also still opportunities for privatisation in major export sectors, such as tourism or shipbuilding, as a substantial part of FDI is still oriented towards non-export sectors. This explains why the share of Croatian exports in key markets has grown less rapidly than the share of exports of comparable countries (see Chart 4.1).

In terms of external financial conditions, Croatia has benefited from the heightened global appetite for risk. The risk premium on euro-denominated assets issued by the Croatian government has been well below JPMorgan's EMBI Global index and has also benefited from the country's investment-grade status (see Chart 4.2). Investors' sentiment has been reinforced by the prospect of EU accession. Nonetheless, the economy remains vulnerable to the potential risks arising from a sudden change in the financial environment. 
Table 4.I Croatia GDP growth and growth contributions

\begin{tabular}{|c|c|c|c|c|c|c|c|}
\hline & 2000 & 2001 & 2002 & 2003 & 2004 & $2005(f)$ & Volatility \\
\hline Real GDP growth & 2.9 & 4.4 & 5.2 & 4.3 & 3.8 & 4.1 & 0.8 \\
\hline Total consumption & 2.1 & 1.1 & 4.1 & 2.5 & 2.3 & 2.3 & 1.0 \\
\hline of which: Private consumption & 2.5 & 2.7 & 4.5 & 2.5 & 2.4 & 2.2 & 0.9 \\
\hline Public consumption & -0.4 & -1.6 & -0.4 & -0.1 & -0.1 & 0.1 & 0.6 \\
\hline Gross fixed capital formation & -0.9 & 1.5 & 2.7 & 4.0 & 1.2 & 0.9 & 1.7 \\
\hline Inventories & -1.5 & 3.2 & 2.7 & -0.7 & -0.2 & 0.8 & 1.9 \\
\hline Balance of goods and services & 3.2 & -1.4 & -4.2 & -1.5 & 0.5 & 0.1 & 2.5 \\
\hline
\end{tabular}

Sources: European Commission and AMECO database, autumn, 2005.

Notes: $(f)=$ forecast (forecast according to the official CBS data for the first three quarters and lastest official CNB porjection for the last three quarters of 2005).

Prudent fiscal policies are key to reducing external vulnerabilities. In the short term, more fiscal prudence would create room for manoeuvre in responding to adverse external shocks. This is especially important in the light of the limited flexibility of monetary policy. In the longer term, reducing external debt, which has stabilised above $80 \%$ of GDP, will be instrumental in enhancing the resilience of the Croatian economy.

\section{Development of Croatia's domestic macroeconomic environment}

Output grew by $4.1 \%$ on average between 2000 and 2005 (see Table 4.1). Throughout, growth was fuelled by household consumption and volatile government investments. Growth rates also reflected changing conditions on the foreign exchange and credit markets, stop-and-go fiscal policies, as well as monetary policy reactions to emerging external and internal imbalances.

Monetary policy aims to strike a balance between external and internal objectives.
Monetary policy aims at keeping a stable kunaeuro exchange rate, although there is no explicit exchange rate target. The tightly managed float strategy employed by the Croatian National Bank (CNB) reflects the fact that the economy is highly "euroised." While parts of the 1990s were characterised by downward pressures on the kuna, particularly during the Asian and Russian crises, more recently, strong capital inflows have created substantial appreciation pressures. Yet, the $\mathrm{CNB}$ has prevented a significant strengthening of the kuna to avoid a deterioration in competitiveness and in order not to provide further incentives for capital inflows.

While the CNB's commitment to exchange rate stability limits its room for manoeuvre, it has been largely successful in achieving price stability. Inflation dropped from the higher levels of 2000 and 2001 to around $2 \%$ in the period 2002-04 (see Table 4.2). This was accompanied by falling nominal interest rates. In 2005, however, inflation edged up again to

\section{Table 4.2 Croatia: Nominal and financial indicators}

\begin{tabular}{|c|c|c|c|c|c|c|}
\hline & 2000 & 2001 & 2002 & 2003 & 2004 & 2005 \\
\hline Inflation (CPI) & 4.6 & 3.8 & 1.7 & 1.8 & 2.1 & 3.3 \\
\hline Zagreb money market overnight interest rate (December value) & 2.4 & 2.5 & 1.6 & 5.5 & 3.6 & 2.3 \\
\hline Real short-term interest rate (contemporaneous) & -2.2 & -1.3 & -0.1 & 3.7 & 1.5 & -1.0 \\
\hline Domestic credit (annual \% change) & 10.1 & 23.2 & 33.6 & 16.8 & 13.1 & 20.3 \\
\hline Exchange rate (euro, period average) & 7.6 & 7.5 & 7.4 & 7.6 & 7.5 & 7.4 \\
\hline Nominal effective exchage rate $(1990=100)$ & 104.8 & 103.4 & 101.2 & 98.2 & 94.8 & 93.5 \\
\hline Real effective exchange rate $(1999=100)$ & 101.5 & 98.7 & 96.3 & 94.2 & 90.7 & 91.1 \\
\hline
\end{tabular}

Source: IFS. 


\section{Table 4.3 Croatia: Fiscal indicators}

\begin{tabular}{|lr|r|r|r|r|r|}
\hline & 2000 & 2001 & 2002 & 2003 & 2004 & 2005 \\
General government balance (in \% of GDP) & -6.5 & -6.7 & -5.0 & -6.3 & -4.9 & -4.2 \\
General government debt (in \% of GDP) $^{2)}$ & 49.5 & 51.1 & 51.3 & 52.5 & 53.5 & 54.2 \\
\hline
\end{tabular}

Sources: MoF and CNB.

1) Modified accrual basis

2) Includes general government debt, CBRD debt and general government guaranteed debt

$3.3 \%$, but this was partly a result of one-off shocks, such as the increase in oil and food prices. CPI developments are expected to remain closely in line with the definition of price stability.

Despite the relative depth of the financial sector, interest rate transmission is weak, reflecting widespread euroisation and the easy access that banks and enterprises have to foreign funds. Against this background, the CNB has been using foreign exchange rate intervention and reserve requirements to absorb excess liquidity and reign in banks' credit expansion. In April 2005 the CNB introduced new, flexible and active monetary policy instruments such as repo, reverse repo etc.

Because of the tightly managed float, fiscal policy is the main policy tool for macroeconomic adjustment. However, for several reasons, fiscal policy has provided only limited support to stabilisation policies. Public finances are overstretched due to structural expenditures such as subsidies for various industries, and high health and pension commitments, which are often inadequately controlled. On the revenue side, authorities regularly face difficulties in collecting the budgeted amount of taxes.

The government has nevertheless made efforts to tighten its control over public finances since 2004. It has been partially successful in offsetting the excessive demand growth caused by private sector spending. However, in mid2005, the Parliament adopted an amendment to the budget law, increasing the deficit target from the original $3.7 \%$ to $4.2 \%$ of the GDP (see Table 4.3). To ensure macro-economic stability, further measures to contain fiscal deficits are crucial.

The external position of the economy remained relatively stable in 2005 . The reduction in the government deficit, the central bank's measures to curb the rapid growth of bank credit, the slowdown of income growth and domestic demand all contributed to this (see Table 4.4). Furthermore, fiscal consolidation and the reorientation of public debt issue toward the domestic market have helped to stabilise government external indebtedness. At the same time, international reserves have continued to

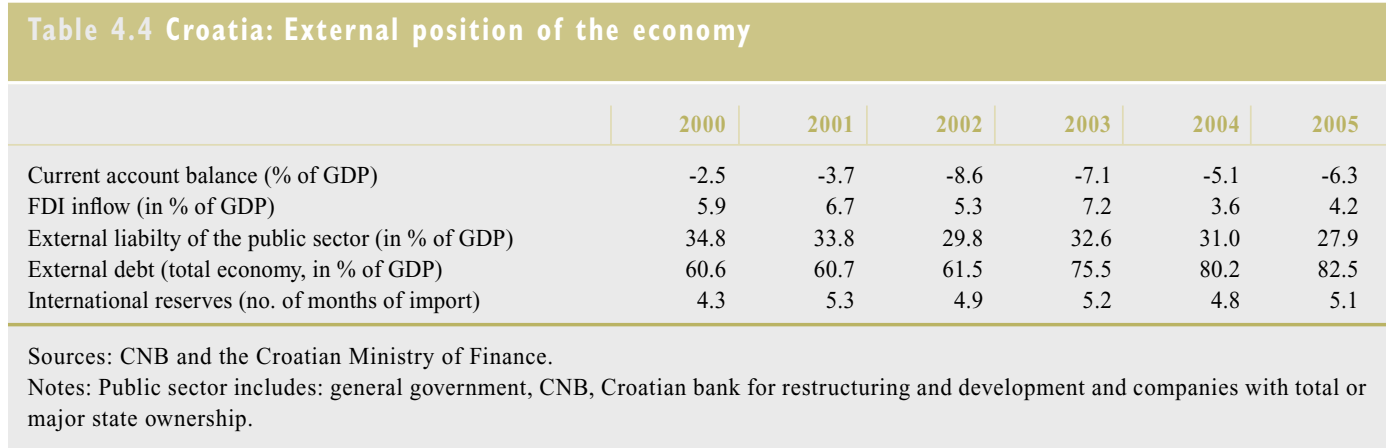


grow in euro terms due to foreign capital inflows and central bank interventions.

\subsection{THE CROATIAN BANIING SECTOR}

\section{STRUCTURE AND DEVELOPMENTS}

A short history of the Croatian banking system Financial sector developments in Croatia have been influenced by the 1998-99 banking crisis, during which the CNB had to intervene in the foreign exchange markets to counter depreciation pressure. The crisis peaked in February and March 1999 and led to the failure of numerous banks. It originated in an excessive lending boom funded by capital inflows as well as in high risk activities of some small and medium-sized banks. The crisis triggered a farreaching privatisation process largely involving foreign investors, which, according to the IMF and the $\mathrm{CNB}$, has been a key factor in creating a stable and well organised banking system. At the same time, the role of banking supervision was reinforced.

\section{The current structure of the Banking System}

The Croatian banking sector is relatively concentrated and dominated by private, foreign ownership (see Table 4.5). By September 2005 the number of banks, which surpassed 60 in 1997 , had fallen to 34 . Of those, private majority foreign owned banks (13) have acquired a dominant market share of $91.2 \%$ of total banking sector assets (one of the largest in Central and Eastern Europe). Italian and Austrian banks are among the biggest foreign investors. Moreover, the banking sector is now almost fully privatised, with private banks holding $96.6 \%$ of total assets. Despite a relatively large number of banks, the banking sector appears relatively concentrated. The four largest banks had a combined market share of $65 \%$ at the end of 2004 . Moreover, the share of the 27 smallest banks amounts to less than $3 \%$ of the total.

The restructuring of the banking sector has been accompanied by institutional reform. The EBRD Index of Banking Sector Reform has shown a continuous rise in the level of reform over the past decade, with the maximum level almost being reached in 2004. Indeed, according to the EBRD, the level of compliance with international solvency standards is high and rated even higher than in the NMS-8.

\section{The Structure of Bank Assets and Liabilities}

Financial intermediation by banks has grown rapidly since the banking crisis of 1998. The ratio of banking sector assets to GDP increased by more than 60 percentage points reaching more than $110 \%$ at the end of 2005 (see Table 4.6). This is higher than in the NMS- 8 ( $75 \%$ of GDP), but is still below euro area levels.

Banks' assets are dominated by claims on households and non-bank corporations, which account for over 55\% of total assets. Owing to administrative measures taken by the CNB, credit growth to the private sector has slowed down over the past few years to a nevertheless substantial $18.5 \%$ in 2005 (see Table 4.9). Until 2004 , lending to enterprises decelerated, whereas

\begin{tabular}{|c|c|c|c|c|c|c|c|}
\hline & 1999 & 2000 & 2001 & 2002 & 2003 & 2004 & $2005^{1)}$ \\
\hline EBRD index of banking sector reform & 3.0 & 3.3 & 3.3 & 3.7 & 3.7 & 4.0 & \\
\hline Number of banks (foreign-owned) & $53(13)$ & $43(21)$ & $43(24)$ & $46(23)$ & $41(19)$ & $37(15)$ & $34(13)$ \\
\hline Asset share of private banks (\%) & 54.4 & 94.3 & 95.0 & 96.0 & 96.6 & 96.9 & 96.6 \\
\hline Asset share of foreign banks $(\%)$ & 39.9 & 84.1 & 89.3 & 90.2 & 91.0 & 91.3 & 91.2 \\
\hline Market share of 4 largest banks in total assets & 58.1 & 62.0 & 60.0 & 58.6 & 61.6 & 64.9 & 65.0 \\
\hline Herfindahl-Hirschmann index ${ }^{2)}$ & 1,190 & 1,368 & 1,315 & 1,237 & 1,270 & 1,363 & 1,361 \\
\hline
\end{tabular}


credit growth to households also fell but remained high. In fact, the share of claims on households in total assets has increased rapidly over the past few years, while that on non-financial corporations has slowly declined. Although loans to households and enterprises with a maturity of longer than one year accounted for around $62 \%$ of total loans by the end of 2004 , the share of long-term corporate loans whose interest rate may vary within a year exceeded $80 \%$ of total corporate loans in $2004 .^{18}$

Claims of the banking sector on the government are relatively low. The share of bank claims on the general government as a ratio of GDP has declined since the end 2000, reflecting institutional factors and the financing of the budget deficit by non-residents. In 2005 it edged up again, accounting for $12 \%$ of total assets. In 2004, the share stood at around 10\%, comparable with the euro area $(9.9 \%)$ and less than in the NMS-8 (14.7\%).

Banks' liabilities are dominated by non-bank deposits, especially from the household sector. By the end of 2005, domestic non-bank deposits accounted for $59.2 \%$ of total liabilities compared with $53.3 \%$ in the NMS- 8 and to $31.7 \%$ in the euro area. Capital and reserves made up $12.8 \%$ of total liabilities and other sources accounted for $28 \%$ (see Table 4.7 ). The share of domestic sectors liabilities has declined in recent years alongside the increasing portion of external liabilities $26.3 \%$ in 2005 , up from $15.3 \%$ in 2001.

Households were the main depositors with Croatian banks (accounting for $65 \%$ of total deposits at the end of 2005), followed by nonfinancial corporations ( $24 \%$ of total deposits). A significant factor in deposit growth was the euro cash changeover. Authorities encouraged the exchange (mostly of the Deutsche Mark) via bank accounts instead of direct cash exchanges. In addition, strengthening confidence in the domestic banking sector has played a role.

The banking sector is characterised by widespread euroisation. Foreign currency deposits, including those denominated in kuna but indexed to foreign exchange rates, accounted

18 Furthermore, $85 \%$ of loans to households with a remaining maturity of over one year were contracted at an interest rate changeable within a year.

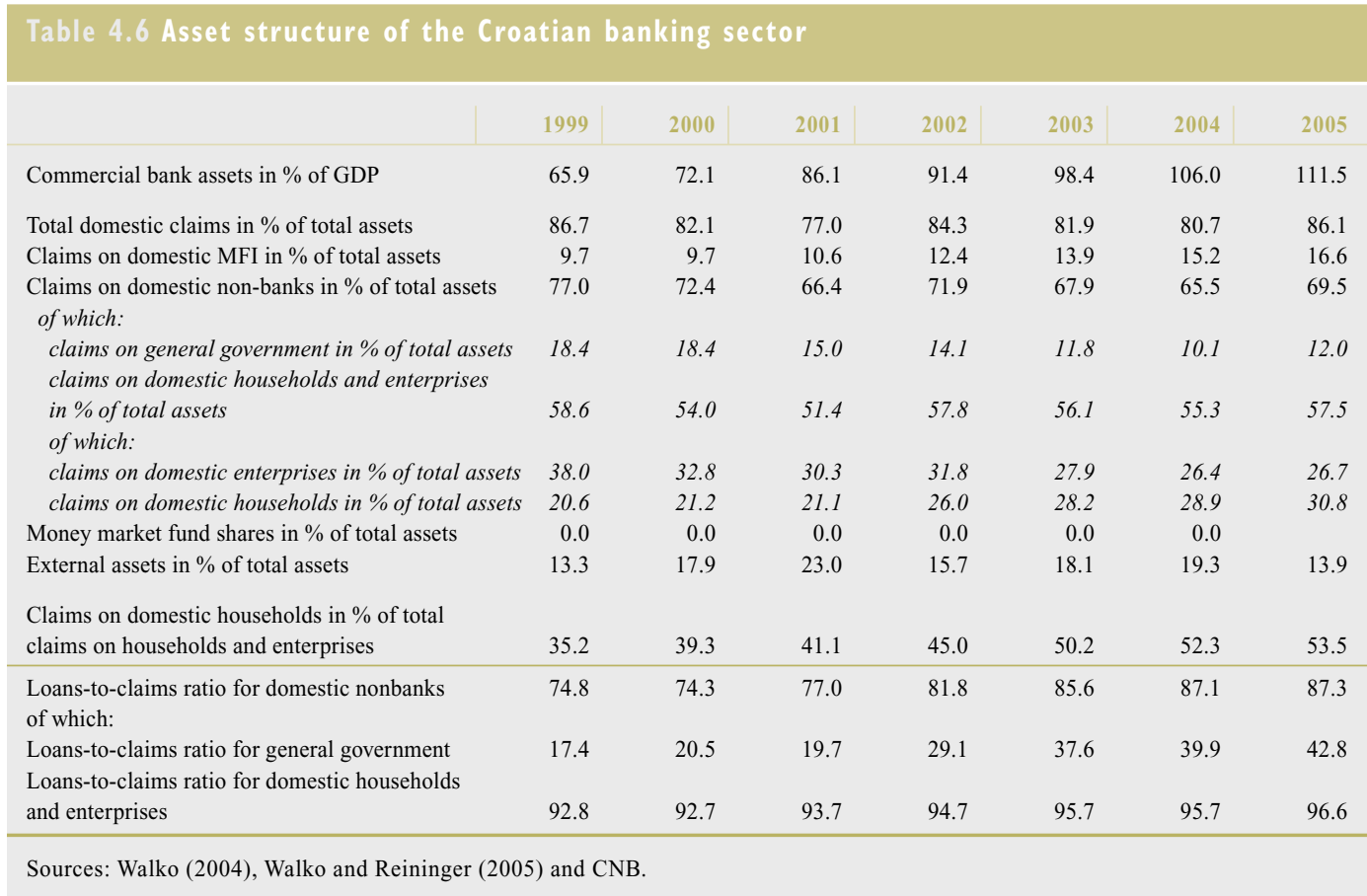


Table 4.7 Liability structure of the Croatian banking sector

\begin{tabular}{|c|c|c|c|c|c|c|c|}
\hline & 1999 & 2000 & 2001 & 2002 & 2003 & 2004 & 2005 \\
\hline \multicolumn{8}{|l|}{ Liabilities as $\%$ of total liabilities } \\
\hline Deposits of MFIs & 1.3 & 0.3 & 0.1 & 0.1 & 0.6 & 0.4 & 2.3 \\
\hline Deposits of domestic non-banks & 63.8 & 68.4 & 73.2 & 68.7 & 63.7 & 60.4 & 59.2 \\
\hline deposits of general government & 6.9 & 7.0 & 4.9 & 5.1 & 4.0 & 4.2 & 4.5 \\
\hline deposits of households and enterprises & 56.8 & 61.4 & 68.3 & 63.6 & 59.7 & 56.2 & 54.7 \\
\hline Money market fund shares & 0.0 & 0.0 & 0.0 & 0.0 & 0.0 & 0.0 & 0.0 \\
\hline Debt securities issued & 0.5 & 0.4 & 0.2 & 0.1 & 0.3 & 0.5 & 0.4 \\
\hline Capital and reserves & 23.6 & 22.7 & 17.9 & 15.9 & 14.0 & 12.7 & 12.8 \\
\hline External liabilities & 18.5 & 16.2 & 15.3 & 21.1 & 25.6 & 27.1 & 26.3 \\
\hline Remaining liabilities & -7.5 & -8.0 & -6.7 & -6.0 & -4.3 & -1.1 & -1.0 \\
\hline \multicolumn{8}{|l|}{ Memorandum items: } \\
\hline Domestic non-banks' claim-to-deposit ratio & 120.8 & 105.9 & 90.7 & 104.6 & 106.6 & 108.4 & 117.4 \\
\hline General government's claim-to-deposit ratio & 266.0 & 262.8 & 304.2 & 273.8 & 293.5 & 242.6 & 266.4 \\
\hline Households' \& Enterprises' claim-to-deposit ratio & 103.1 & 88.0 & 75.3 & 90.9 & 94.0 & 98.4 & 105.1 \\
\hline
\end{tabular}

Sources: Walko (2004), Walko and Reininger (2005) and CNB.

for $85 \%$ of total deposits at the end of 2005 , showing almost no downward trend since 2001. The proportion of foreign currency (indexed) loans (mostly in euro) is also high and exceeded $75 \%$ of total loans at the end of 2005 .

Domestic credit expansion has been funded largely by banks' external borrowing (see Table 4.7). Consequently, the Croatian banking sector's net foreign assets have turned negative, reaching $-12.4 \%$ of total assets by the end of 2005. Gross external debt of banks (excluding the CNB) made up roughly $30 \%$ of GDP and the end of 2004 (compared with approximately $12 \%$ at the end of 2001).

\section{The Profitability of the Banking System}

Owing to an improvement in cost management and overall efficiency, the profitability of the banking sector has increased over the past few years (see Table 4.8). ${ }^{19}$ The cost-to-income ratio

19 Owing to the fall in interest rates, net interest income as a percentage of average assets and the share of net interest income in operating income declined from 2001 to 2005 (from 3.5\% to $3 \%$ and from around $80 \%$ to $70 \%$ respectively), while net noninterest income as a percentage of average assets rose slightly. Operating income remained almost stable at 4 to $4.5 \%$ of average assets. By cutting general administrative expenses the operating costs as a percentage of average assets were reduced in the same period and the cost-to-income ratio declined from $65 \%$ to $54 \%$. After the crises of 1998 and 2001 the high net costs of loan provisioning as a percentage of operating income could be largely reduced and has stood at $5 \%$ to $7 \%$ in the past few years.

\section{Table 4.8 Profitability of the Croatian banking sector}

\begin{tabular}{|c|c|c|c|c|c|c|}
\hline & 2000 & 2001 & 2002 & 2003 & 2004 & 2005 \\
\hline Total operating income & 100.0 & 100.0 & 100.0 & 100.0 & 100.0 & 100.0 \\
\hline Net interest income in \% of total income & 68.6 & 78.8 & 70.8 & 74.3 & 69.2 & 70.4 \\
\hline Net non-interest income in \% of total income & 31.4 & 21.2 & 29.2 & 25.7 & 30.8 & 29.6 \\
\hline General administrative expenses in $\%$ of total income & 56.7 & 65.6 & 59.3 & 56.9 & 54.3 & 59.1 \\
\hline Loan loss provision expenses in $\%$ of total income & 20.6 & 13.7 & 6.6 & 7.7 & 6.6 & 4.9 \\
\hline Income tax in $\%$ of total income & 2.0 & 5.7 & 6.3 & 5.9 & 6.4 & 7.9 \\
\hline After-tax profit $/$ loss in $\%$ of income & 20.7 & 15.2 & 27.8 & 29.5 & 32.6 & 33.7 \\
\hline Net interest income in $\%$ of average assets & 4.2 & 3.6 & 3.3 & 3.4 & 3.0 & 2.9 \\
\hline Net non-interest income in $\%$ of average assets & 1.9 & 1.0 & 1.3 & 1.1 & 1.3 & 1.2 \\
\hline Interest rate spread (total loans - total deposits) & 7.6 & 6.6 & 7.7 & 8.0 & 7.6 & 7.0 \\
\hline Return on average assets - before tax (in \%) & 1.4 & 0.9 & 1.6 & 1.6 & 1.7 & 1.7 \\
\hline Return on average equity (in \%) & 10.7 & 6.6 & 13.7 & 14.5 & 16.1 & 15.6 \\
\hline Net interest margin & 3.8 & 3.1 & 3.0 & 3.5 & 3.1 & $\ldots$ \\
\hline
\end{tabular}


seems to be below those of the NMS and the euro area. The structure of non-performing loans has also improved.

\section{RISKS AND SHOCK-ABSORBING CAPACITIES}

\section{Credit risk}

The prime risk for Croatian banking sector is credit risk. Credit growth to the private sector peaked at $24.7 \%$ and $31.6 \%$ in 2001 and 2002 respectively (see Table 4.9). As this rapid expansion of credit was being financed increasingly through external borrowing, mainly from parent banks, the CNB introduced higher reserve requirements, especially for foreign credit, and made it mandatory for commercial banks to keep a minimum of foreign exchange liquid assets. Consequently, credit growth to the private sector as a whole slowed down initially but edged up again in 2005. At the same time, lending to households has continued to rise rapidly. This can be attributed to the fact that the corporate sector increasingly resorted to direct borrowing from foreign banks and non-bank financial institutions (leasing), as well as to increases in trade credit. The household sector has limited access to these sources of credit and banks have found enough capital and liquidity to continue expanding their lending to private households.

Credit risk from the household sector appears to be on the rise as debt levels and debt service burdens increase. The estimated household debt-to-GDP ratio rose from $19 \%$ in 2001 to almost 34\% in June 2005 (see Table 4.10). According to the $\mathrm{CNB}$, this mainly reflects strong growth in household borrowing from banks. While Croatia's household debt-to-GDPratio is still below its average ratio in the euro

\begin{tabular}{|c|c|c|c|c|c|c|}
\hline & 2000 & 2001 & 2002 & 2003 & 2004 & 2005 \\
\hline \multicolumn{7}{|l|}{ Risks } \\
\hline \multicolumn{7}{|l|}{ Credit risk } \\
\hline Credit growth (annual percentage change) & 10.1 & 23.2 & 33.6 & 16.8 & 13.1 & 20.3 \\
\hline Credit growth to the private sector (annual percentage change) & 8.5 & 24.7 & 31.6 & 15.9 & 13.6 & 18.5 \\
\hline Real credit growth to the private sector (annual percentage change) & 1.4 & 17.2 & 27.5 & 13.1 & 11.3 & 16.2 \\
\hline Credit growth to households (annual percentage change) & 21.0 & 29.3 & 43.0 & 27.7 & 18.7 & 20.3 \\
\hline Mortgage credit (housing loans) growth (annual percentage change) & 10.6 & 14.4 & 30.8 & 36.7 & 26.6 & 28.8 \\
\hline Non-performing loans ( $\%$ of total loans) & 9.5 & 7.3 & 5.9 & 5.1 & 4.5 & 4.0 \\
\hline Share of foreign currency credit in total private sector credit & 85.6 & 84.9 & 80 & 74.4 & 75.8 & 77.5 \\
\hline Share of foreign currency deposits in total deposits & 91.3 & 91.2 & 89.4 & 87.1 & 86.8 & 84.3 \\
\hline \multicolumn{7}{|l|}{ Market risk } \\
\hline \multicolumn{7}{|l|}{ Forex risk } \\
\hline Open FX position in $\%$ of total balance sheet assets & 3.5 & 0.4 & 1.4 & 1.6 & 1.0 & 0.5 \\
\hline \multicolumn{7}{|l|}{ Stock market risk } \\
\hline Ratio of shares and participations to total assets (equity holdings) & 1.1 & 1.0 & 0.6 & 0.4 & 0.2 & 0.1 \\
\hline \multicolumn{7}{|l|}{ Liquidity risk } \\
\hline Ratio of liquid assets ${ }^{1)}$ to total assets & 31.5 & 37.6 & 29.7 & 32.8 & 31.3 & 28.0 \\
\hline Ratio of total loans to total deposits & 70.5 & 62.9 & 74.1 & 76.6 & 80.6 & 88.5 \\
\hline Ratio of liquid assets ${ }^{1)}$ to short-term liabilities & 110.4 & 126.7 & 97.7 & 117.2 & 120.4 & 104.5 \\
\hline \multicolumn{7}{|l|}{ Shock-absorbing factors } \\
\hline Loan loss provisions (as a perecentage of non-performing loans) & 79.9 & 71.8 & 68.1 & 60.8 & 60.3 & 58.0 \\
\hline Capital adequacy ratio & 21.3 & 18.5 & 17.2 & 16.2 & 14.1 & 15.8 \\
\hline \multicolumn{7}{|l|}{ Memo } \\
\hline Number of banks (foreign-owned) & $43(21)$ & $43(24)$ & $46(23)$ & $41(19)$ & $37(15)$ & ... \\
\hline Asset share of foreign-owned banks (in \%) & 84.1 & 89.3 & 90.2 & 91 & 91.3 & $\cdots$ \\
\hline
\end{tabular}


area, it is roughly estimated to be twice as high as in the NMS-8. Moreover, the debt of households in relation to gross disposable income rose rapidly from $28 \%$ to more than $70 \%$ and debt service to gross disposable income ratio increased from $3.6 \%$ in 2000 to $6 \%$ in 2004 , despite a decline in interest rates.

Banks' exposure to the corporate sector has grown less rapidly. By the end of 2004, bank claims on the corporate sector accounted for only $48 \%$ of total claims on households and non-bank corporations, whereas in the euro area they accounted for $56 \%$. The estimated total debt of non-financial enterprises rose from around $43 \%$ of GDP at the end of 2001 to almost $50 \%$ in June 2005. In the past few years, their external debt increased by rates of around around $18 \%$, and their debt to leasing companies grew at three-digit rates.

Rapid credit growth may lead to higher credit risk through a number of channels. First, debt levels and debt service burdens have increased, making debtors more vulnerable to any kind of shock. Second, rapid credit growth may entail lower vetting standards and thereby cause lending to less creditworthy customers. Furthermore, local managers of foreign banks may be more concerned about lending volumes than the risks of such a high growth environment. Anecdotal evidence suggests that banks have indeed begun more risky lending, for instance by accepting loans with debt service burdens in excess of $50 \%$ of disposable income.

Foreign-currency related risk is an important part of credit risk and stems from the high proportion of banking system activity denominated in or linked to euro. ${ }^{20}$ Domestic borrowers that are not foreign exchange earners bear the bulk of foreign exchange risk. While this risk is somewhat mitigated by the fact that most deposits are also in euro, net debtor households still bear foreign exchange rate risk and the structure of credit commitments directly exposes households to a high level of currency risk.
Households'borrowing in currencies other than the euro is increasing, particularly in the Swiss franc $(11 \%$ of total households' borrowing in September 2005). The CNB is trying to improve the monitoring of borrowers' exposure to foreign exchange risk and further strengthen supervision. This includes requiring banks to collect information on their borrowers' foreign currency exposure as part of their credit risk evaluation, and issuing a guideline for banks to report their exposures to foreign-exchange induced credit risk to the CNB.

The influx of foreign banks (mostly from the euro area) in the aftermath of the 1998-99 domestic banking crisis has played a key role in bringing credit risk management standards closer to international best practices. ${ }^{21}$ Furthermore, the share of non-performing loans in total loans has declined in recent years from the peak that followed the eruption of the banking crisis. In the period 2000-2005, it decreased from $9.5 \%$ to $4 \%$.

\section{Market and liquidity risk}

The Croatian banking sector's exposure to interest rate risk appears to be relatively small, both in terms of income and the balance sheet. In 2005 net interest income accounted for $70 \%$ of operating income, a share which has been falling in favour of non-interest income, such as commissions. This income diversification has somewhat reduced the exposure of the banking sector to adverse interest rate movements. Although the spreads between lending and deposit rates are higher than in advanced economies, this is mainly due to substantial but declining overhead costs,

20 Most loans are not granted directly in euro but in kuna indexed to the euro. In particular, the relatively low interest rates for foreign-currency-denominated or foreign-currency-indexed loans have stimulated the growth of these credit categories. According to the CNB, the ongoing euroisation (especially of deposits) in the banking sector, in an environment of low inflation, is due to the fear of a depreciation of the kuna and another period of high inflation. The role of the euro in the domestic banking sector is therefore not directly linked to the presence of banks from the euro area.

21 Whilst the high incidence of foreign currency lending is not necessarily in line with international best practice, it is a complement to the supply of euro deposits and an almost completely fixed exchange rate. 


\begin{tabular}{|c|c|c|c|c|c|c|}
\hline & 2000 & 2001 & 2002 & 2003 & 2004 & June 2005 \\
\hline \multicolumn{7}{|l|}{ Debt } \\
\hline \multicolumn{7}{|l|}{ Households } \\
\hline as \% of GDP & 15.9 & 19.0 & 24.9 & 29.6 & 32.8 & 33.9 \\
\hline as $\%$ of gross disposable income & 28.1 & 36.9 & 49.2 & 63.3 & 70.2 & 72.5 \\
\hline$y-0-y$ rate of change & 21.1 & 29.6 & 42.2 & 27.8 & 18.9 & 21.0 \\
\hline Implicit interest payments, as \% of gross disposable income & 2.9 & 3.9 & 4.4 & 5.7 & 6.0 & 6.1 \\
\hline $\begin{array}{l}\text { Non-financial enterprises } \\
\text { as } \% \text { of GDP }\end{array}$ & 42.9 & 42.9 & 45.3 & 46.3 & 49.2 & 49.7 \\
\hline as \% of corporate bank deposits & 428.9 & 352.0 & 306.9 & 290.0 & 303.5 & 338.7 \\
\hline$y-o-y$ rate of change & 4.1 & 8.5 & 14.6 & 10.4 & 13.3 & 12.5 \\
\hline Implicit interest payments, as \% of GDP & 3.8 & 3.4 & 3.2 & 3.1 & 2.9 & 2.9 \\
\hline \multicolumn{7}{|l|}{ Total non-financial private sector } \\
\hline$y-0-y$ rate of change & 8.2 & 14.2 & 23.1 & 16.5 & 15.4 & 15.8 \\
\hline \multicolumn{7}{|l|}{ General government } \\
\hline$y-0-y$ rate of change & 28.7 & 11.6 & 10.6 & 12.7 & 14.5 & 11.6 \\
\hline interest paid as $\%$ of GDP & 1.8 & 1.9 & 2.0 & 2.0 & 2.1 & 2.2 \\
\hline \multicolumn{7}{|l|}{ Total non-financial sector } \\
\hline $\begin{array}{l}\mathrm{y} \text {-o-y rate of change } \\
\mathrm{a}\end{array}$ & $\begin{array}{l}99.4 \\
15.7\end{array}$ & $\begin{array}{r}105.0 \\
13.2\end{array}$ & $\begin{array}{r}112.9 \\
18.1\end{array}$ & $\begin{array}{r}120.8 \\
15.1\end{array}$ & $\begin{array}{r}129.6 \\
15.1\end{array}$ & $\begin{array}{r}132.6 \\
14.2\end{array}$ \\
\hline
\end{tabular}

reflecting the low productivity of banks and possibly also differences in the risk profiles of borrowers. Overall, the interest rate risk in terms of income seems limited. In terms of the balance sheet, interest risk is, at least formally, negligible because most loans, even "fixed interest" loans, carry a provision that the interest rate can be changed at will and time deposits rarely have a maturity of over a year. This means that most of the interest rate risk has been passed on to the customer and may filter back through credit risk in the event of adverse macroeconomic shocks.

Equity price risk is limited, as the ratio of shares and participations to total assets has declined to much less than $1 \%$, and both available-for-sale and held-for-trading assets and liabilities have accounted for only a small part of income (and loss).

The exposure of banks to direct foreign exchange rate risk is limited. The share of foreign currency deposits is high, but the CNB has put a limit of $20 \%$ on the ratio of the total open foreign exchange position to regulatory capital. This ratio stood at $4.2 \%$ in the second quarter of 2005 , which is a substantial decrease from $7.2 \%$ in 2004. Moreover, if the kuna were to depreciate, this long position would provide a partial hedge against the increase in credit risk that would result due to the short position of the banks' counterparties (see above).

In general, it appears that most of the market risk has been passed on to customers, which means that these risks are likely to resurface through credit risk. Moreover, it seems plausible that in particular some of the foreign exchange rate risk and interest rate risk now borne by customers could be better managed by banks themselves. By passing these risks to customers, they have made them harder to control, which could be to their own disadvantage in the event of a large macroeconomic shock.

Liquidity risk has been increasing but is still low, as the system as a whole is still relatively liquid. The decline in the ratio of liquid assets to total assets and the rise in the loan-to-deposit 
ratio point to a deterioration in liquidity in the Croatian banking sector over the past few years. This can be partly attributed to the CNB's active policy to reduce liquidity through administrative measures, such as special reserve requirements on foreign currency assets. ${ }^{22}$ But, despite these measures, liquidity is still high, which is also reflected in the large amounts of free reserves held at the central bank. Stress tests by the CNB suggest that banks would withstand a substantial $(35 \%)$ one-off deposit outflow. At the same time, however, international financing risk has been growing due to an increasing share of liabilities being owed to non-residents. Even though most of these are owed to foreign banks, which are, in most cases, probably the parent banks, this development warrants monitoring.

\section{Shock-absorbing factors}

Profitability remains relatively high and provides a buffer against shocks. For the banking system as a whole, the return on average assets was $1.7 \%$ at the end of 2005 , while the return on average equity stood at $16 \%$ (see Table 4.8 ).

Banks appear well capitalised, and, despite a decreasing trend, capital adequacy ratios remain well above requirements. Commercial banks' capital adequacy ratios ranged between 14 and 16\% during 2003 and 2005, and all banks posted capital adequacy ratios in excess of the minimum $10 \%$ statutory limit. Following the new Banking Law (2002) and by-laws, market risk coverage is now included in the capital adequacy calculation. However, capital formally assigned to non-credit risk constitutes only $3.9 \%$ of total capital (June 2005), which seems low, even for the limited market risks of the Croatian banks. Moreover, banks do not take operational risk into account. That said, given that banks have capital ratios in excess of regulatory requirements, they appear sufficiently well capitalized to withstand shocks related to operational and market risk. Stress tests by the CNB using 2004 year-end data show that credit risk still poses the greatest threat to the Croatian banking system but that most banks would be able to tolerate substantial losses arising from asset deterioration.
Moreover, the stress tests find small banks to be even less vulnerable to credit risk shocks than the large banks.

Foreign ownership may be seen as an additional shock absorption factor. In the event of idiosyncratic shocks, foreign banks are likely to have sufficient reserves to recapitalise their comparatively small Croatian subsidiaries. Both the reputation risk associated with letting a subsidiary fail and the strategic nature of investments in this region may provide an incentive for them to do so. However, the extent to which this would happen in practice also depends on the internal risk and profitability assessment of the parent bank.

\subsection{SUMMARY AND CONCLUSIONS}

Croatia's main macroeconomic challenge relates to the external factors. Export performance is highly dependent on tourism, and Croatian exports have been relatively slow in penetrating major export markets. This raises concerns about medium-term competitiveness and may have an impact on the current account. It is therefore important to contain the growing external debt (including from banks), which is associated with rapid capital inflows. Monetary policy has, however, little room for manoeuvre, given the tightly managed floating exchange rate regime and the high degree to which financial assets and liabilities are denominated in foreign currency, particularly in euro. Against this background, the CNB has adopted a series of restrictive administrative and prudential measures to curb foreign borrowing by banks and domestic credit growth. Since such measures tend to be circumvented, fiscal policy ought to play a greater role in the macroeconomic adjustment process in order to moderate the impact of the sizeable capital inflows.

22 The CNB introduced the marginal reserve requirement on external borrowing and then raised it several times to $55 \%$ in December 2005; it also increased the foreign exchange reserve requirement calculation base, allocated in kuna, from $42 \%$ to $50 \%$ and reduced the remuneration rates on both the kuna and foreign exchange components of the reserve requirements. 
The Croatian financial sector is largely bankbased, private and foreign-owned and relatively concentrated. Rapid credit growth has been associated with a decrease in the net foreign asset position of banks. Claims on the corporate sector are high, but have been falling vis-à-vis the household sector, due to the cross-border and non-bank financing of enterprises. Banking sector assets and liabilities are predominantly denominated in or indexed to foreign currency, mostly the euro.

The prime risk the banking sector is exposed to is credit risk. The common indicators of asset quality are still positive, but credit risk may be rising due to high credit growth. Despite the restrictive measures taken by the $\mathrm{CNB}$, credit growth to the household sector has remained high, leading to rapidly rising debt levels and an increasing debt service burden. This is indicative of a considerable increase in credit risk, as most of the interest and exchange rate risk has been passed on to borrowers. Consequently, market risks are likely to resurface through credit risk in the event of serious shocks. Against this background it is reassuring that the Croatian banking sector is well-placed to absorb shocks due to its relatively high profitability and capitalisation.

\section{TURKEY \\ 5.I MACROECONOMIC DEVELOPMENTS AND VULNERABILITIES}

Development of Turkey's external environment

With total trade in goods and services representing roughly $60 \%$ of GDP, Turkey is somewhat more closed than most of the current EU members, although it has opened up significantly over the past ten years. The geographical composition of international trade has been quite stable. The EU is Turkey's principal trading partner and accounts for roughly half of its international trade.

While external demand is likely to grow in line with the EU economy, Turkey has recently faced

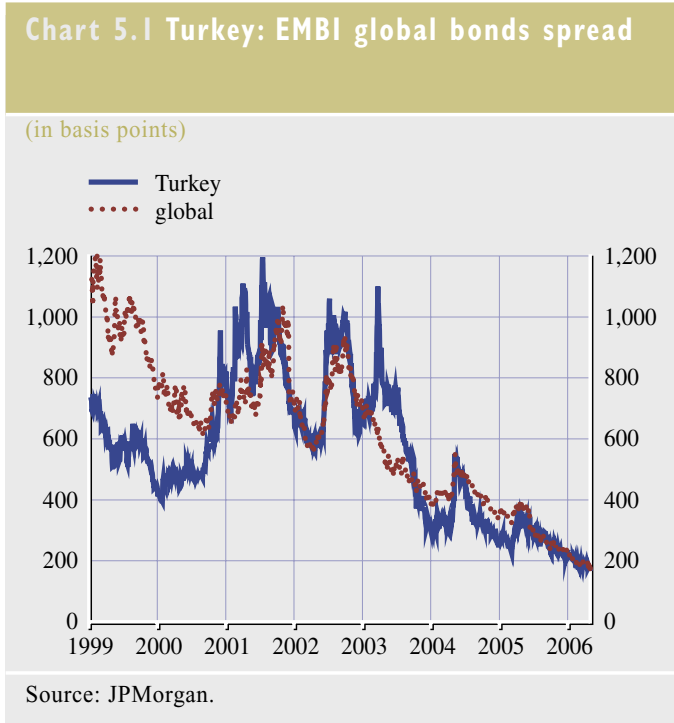

an adverse external trade environment. Turkey's trade balance has recently deteriorated as a result of specific terms-of-trade shocks, both on the import and export sides of the current account. On the importing side, Turkey has suffered from the elevated oil and energy prices, and on the exporting side, textiles, which account for $30 \%$ of total export earnings and contribute about $10 \%$ of output, have shown signs of stress following the elimination of international textile quotas in early 2005 .

External balances have therefore deteriorated. The combination of an appreciating lira with specific terms-of-trade shocks has contributed to a widening current account deficit $(6.3 \%$ of GDP in 2005). However, export profit margins have been well above pre-crisis levels, while some of the adverse exchange rate dynamics are being offset by subdued wage developments and strong productivity growth.

However, like most emerging market economies, Turkey benefited from improved financing conditions over the past years. A continuous strengthening of macroeconomic fundamentals and improving prospects for EU accession have also contributed to the improvement in financing conditions, as illustrated by credit rating upgrades from Standard \& Poor's and Fitch in late 2004 and early 2005 respectively, the sharp 
decline in Turkish bond spreads (see Chart 5.1) and strong capital inflows. Against this background, capital inflows have reached an all-time high of more than USD 40 billion in 2005, thereby amply financing the current account deficit, though capital inflows have been mostly of a debt-creating nature rather than FDI.

\section{Development of Turkey's domestic} macroeconomic environment

Following a crisis in 2001, Turkey's robust growth record has been underpinned by improved macroeconomic policies. Over the period 2002-05, average economic growth exceeded $7 \%$ per annum. Since the crisis, the Turkish authorities have adhered to a primary surplus target of $6.5 \%$ of GDP (which is the cornerstone of IMF conditionality). This policy has helped to reduce Turkey's net public indebtedness that, in the face of a costly banking sector recapitalisation, peaked at over $90 \%$ of GDP in 2001. Continued fiscal restraint has also contributed to strong disinflation, from nearly $100 \%$ in 2000 to within a single digit range, despite the sharp depreciation of the lira in 2001. Besides the strengthening of budgetary

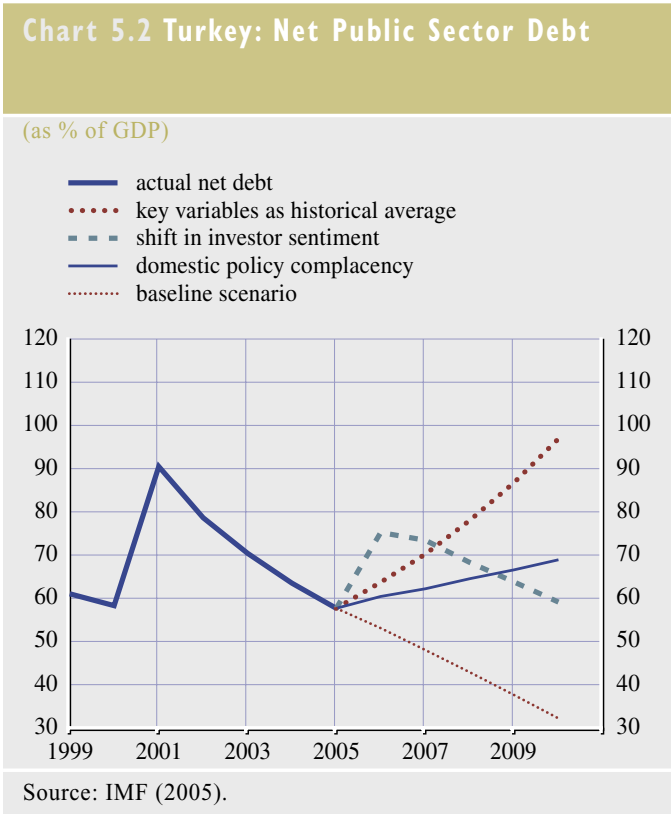

discipline, other contributing factors have been wage restraint in the public sector, a switch from backward to forward-looking wage indexation, the increasing credibility of the price stability objective of the Central Bank of the Republic of Turkey (CBRT) and the strengthening of the Turkish lira from 2002 onwards. Against this background, the CBRT has eased policy interest rates in line with the decline in inflation expectations.

Public debt sustainability analyses highlight Turkey's exposure to financial market conditions. Analysis conducted by the IMF suggests that under a baseline scenario of economic growth of $5 \%$, continued adherence to an ambitious surplus target of $6.5 \%$ of GDP and real interest rates of $8 \%$, the public debt ratio would show a rapid downward trend. However, a combination of shocks would severely threaten public debt sustainability (see Chart 5.2). Moreover, under a scenario of policy complacency, in which the primary balance is permanently reduced to $4 \%$ of GDP, privatisation is cancelled, real interest rates rise by four percentage points and economic growth slows down to $2.5 \%$ per annum, public debt would rise steadily.

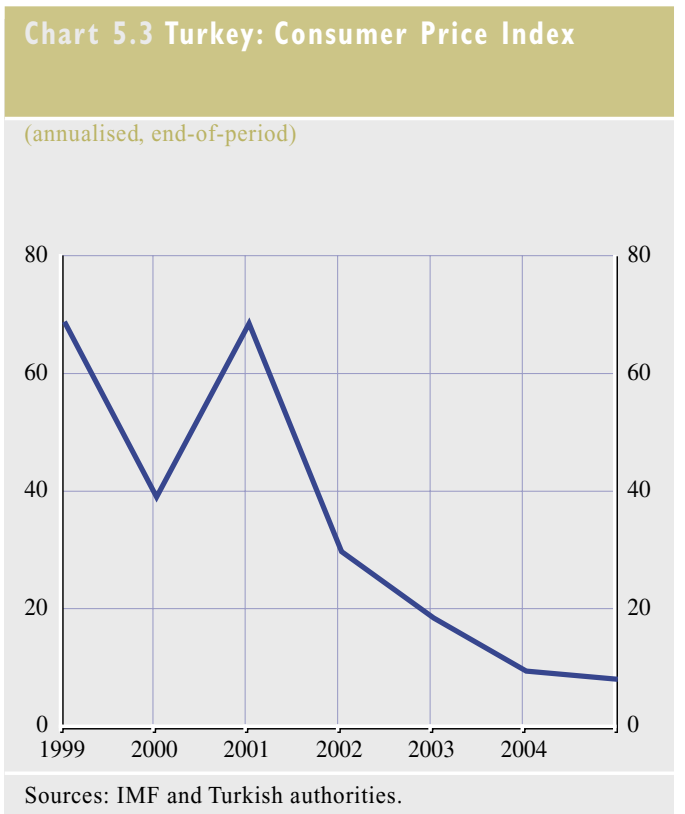


Continued commitment to sound macroeconomic policies remains crucial for ensuring debt sustainability and further inflation reduction (see Chart 5.3). The current level of gross public indebtedness is still relatively high at more than $70 \%$ of GDP in 2005 , and debt interest payments still accounted for more than $50 \%$ of total tax revenue in 2004 . Furthermore, a large fraction of the public sector debt stock is indexed, either to the exchange rate or to overnight interest rates. This implies that public debt sustainability largely depends on the prevailing financing conditions. Owing to the benign financing conditions, real interest rates have dropped to $7-8 \%$. This is historically low for Turkey, but still high in comparison with the other EU acceding and candidate countries, highlighting the continued importance of confidence-inspiring economic policies and strict compliance with the structural benchmarks agreed in Turkey's programme with the IMF.

Since the crisis in 2001, the Turkish authorities have made significant headway in restructuring the financial sector, but now face the additional challenge of buoyant credit growth. While real interest rates remain high, they have declined substantially prompting a surge in the demand for credit. Notwithstanding the much improved health of the financial sector, the acceleration of private sector credit growth presents a major challenge for the Turkish authorities, not least because of its stimulating effect on domestic demand and the consequent widening of the current account deficit. This development warrants intensive monitoring, since experience shows that a substantial proportion of credit booms end in a banking crisis. However, in the case of Turkey, there are some mitigating factors at play. First, at $25 \%$ of GDP, Turkey's ratio of private credit to GDP is significantly lower than in Central and Eastern European countries. Second, rapid credit growth may be interpreted as an indication that the Turkish commercial banking sector is reorienting its activities towards the private sector. In the preceding decade, commercial lending was almost marginalised, as the share of government

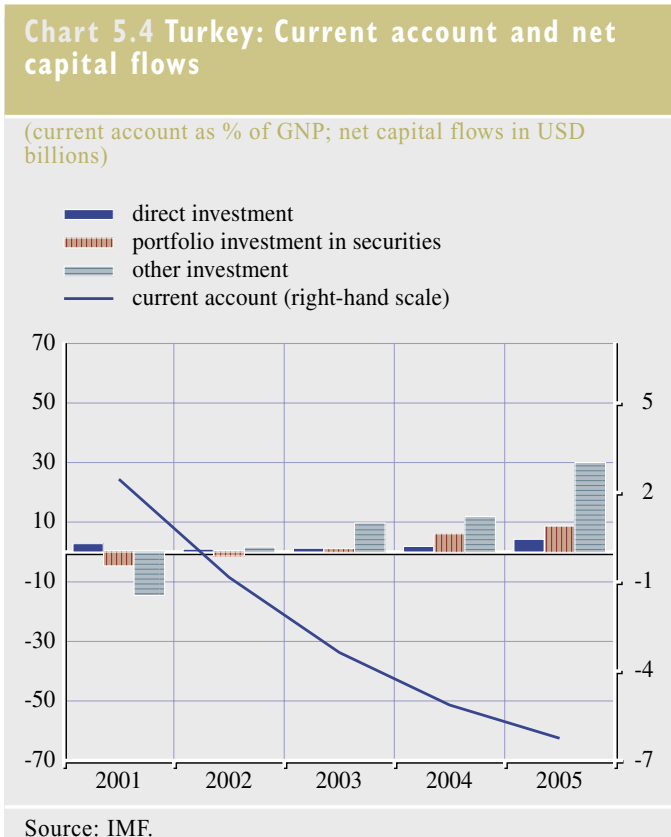

securities in the banking system's total assets reached $60 \%$, thereby crowding out the provision of credit to the private sector.

Despite record capital inflows, macroprudential indicators of the economy's liquidity and solvency suggest a number of vulnerabilities. The current account deficit is amply financed by record capital inflows (see Chart 5.4), but several developments warrant vigilance. First, short-term debt-creating inflows constitute the lion's share of total capital inflows into Turkey. However, reflecting new arrangements in the investment environment (including an FDI law aimed at ensuring the equal treatment of foreign and domestic investors that was approved in June 2003), the composition of capital inflows has recently displayed some improvement, as FDI has increased from traditionally low levels.

Second, conventional solvency and liquidity indicators indicate some vulnerability. At roughly $50 \%$ of GDP, the level of gross external indebtedness is relatively high compared with other emerging market economies. Debt servicing obligations expressed as a share of total exports are also relatively high, at around 
$60 \%$. Turning to liquidity indicators, short-term external debt (debt with a residual maturity of less than one year) is not fully covered by international reserves. However, reserve coverage is increasing, reflecting significant central bank purchases amounting to USD 21 billion in 2005. This is an encouraging development given that Turkey will have to make significant repayments to the IMF in the near future and that private short-term external debt has been rising.

\subsection{THE TURKISH BANKING SECTOR}

\section{STRUCTURE AND DEVELOPMENTS}

\section{The Turkish banking sector before the crises of 2000 and $200 \|$}

Turkey's recent financial history has been marked by repeated crises, most recently in 2000 and 2001. During the 1990s, Turkey's macroeconomic situation was characterised by volatile growth, high inflation and an ever increasing debt problem. To address the situation, an IMF-backed disinflation programme based on an exchange rate anchor was introduced at the start of 2000. However, during 2000 and 2001, the Turkish banking sector, which constitutes over $90 \%$ of the Turkish financial sector, experienced two severe crises that had far-reaching consequences for the rest of the economy. In mid-2000, the government took steps towards addressing some of the problems in the banking sector, including the provision of subsidised credit to various political constituencies by state-owned banks, which resulted in "duty losses" that had to be covered by the government. Despite the reform efforts, volatility in international capital markets and deteriorating economic conditions in Turkey resulted in significant losses in the banking system. In November 2000, Demirbank, a medium-sized private bank, was unable to roll over its overnight liabilities and liquidated large quantities of government securities. The following collapse in the value of government bonds prompted creditors to refuse to roll over overnight credit, which triggered a capital outflow and a sharp fall in Turkey's international reserves.

The banking crisis culminated in a currency crisis which only abated when the exchange rate was freely floated. In December 2000, the IMF and the Turkish authorities agreed on a rescue package in order to avoid the unravelling of the existing disinflation programme, but the respite was short-lived. Inflation did not come down as quickly as initially planned, which put into question the crawling peg and the prearranged and gradually widening exchange rate path. In addition, foreign investors withdrew from the Turkish market due to the political uncertainty and fears that the stabilisation policies may be reversed. On 22 February 2001, the authorities floated the Turkish lira to avoid further reserve losses. Bank runs were avoided thanks to the announcement of a blanket guarantee protecting depositors and other creditors in banks (except shareholders' equity and subordinated debt).

\section{New beginnings: the structure of the Turkish} banking sector after 2001

Following the crisis, a costly but successful bank restructuring process was launched with the support of the IMF and the World Bank. This substantial restructuring process consisted of four pillars: (i) the restructuring of the stateowned banks; (ii) the resolution of the banks transferred to the Savings Deposit Insurance Fund (SDIF); (iii) the strengthening of the privately owned banks; and (iv) reforming the regulatory and supervisory environment to enhance surveillance of the sector. All in all, the process cost slightly over USD 47 billion, or over $30 \%$ of GDP (2003).

Given the limited level of financial intermediation, there is considerable potential for the development of core banking activities. The total size of Turkish banking sector assets over GDP only stood at $69 \%$ at the end of 2003 , and $72 \%$ at the end of 2004 , which is low compared with the EU-15 and the new EU Member States. By the end of 2004, liquidations, 


\begin{tabular}{|c|c|c|c|c|}
\hline & $\begin{array}{l}\text { Number of } \\
\text { institutions }\end{array}$ & $\begin{array}{c}\text { Share of total } \\
\text { assets in \% }\end{array}$ & $\begin{array}{c}\text { Share of total } \\
\text { loans in } \%\end{array}$ & $\begin{array}{l}\text { Share of total } \\
\text { deposits in \% }\end{array}$ \\
\hline State-owned commercial banks & 3 & 31.4 & 20.0 & 37.7 \\
\hline Privately owned commercial banks & 17 & 59.0 & 67.0 & 57.0 \\
\hline Foreign-owned commercial banks & 13 & 5.7 & 7.5 & 5.3 \\
\hline SDIF banks & 1 & 0.5 & 0.0 & 0.0 \\
\hline Non-depository banks & 13 & 3.4 & 5.5 & 0.0 \\
\hline Total & 47 & 100.0 & 100.0 & 100.0 \\
\hline
\end{tabular}

mergers and acquisitions had reduced the number of banks in the Turkish banking sector from 81 at the end of 1999 to 48, representing $91.4 \%$ of total financial sector assets (or $85 \%$ of assets including financial investment companies and mutual funds). At the same time, the share of the five largest banks represented $60 \%$ of total banking sector assets compared with $48 \%$ at the end of 2000 .

The Turkish banking sector still has a significant presence of state-owned banks (see Table 5.1), which make up $31 \%$ of total banking sector assets. Privately owned commercial banks have increased their share to 59\% (as of September 2005), largely at the expense of banks managed by the Savings Deposit Insurance Fund (SDIF). Out of a total of 21 banks that had been taken over by the SDIF because they had become a risk for banking system stability, 20 have been either merged, sold or in one case liquidated.

Foreign interest in the Turkish banking sector has increased and may lead to further consolidation in the sector. Mergers and acquisitions may continue in the near future, partly due to increased interest from foreign banks, which have already acquired majority stakes in some Turkish banks. This interest has long been subdued because of the vulnerabilities and risks in the sector, coupled with the particular ownership structure of Turkish banks. Privately owned banks are predominantly owned by family conglomerates, which have traditionally been more interested in extending credit to related enterprises and holding
Treasury bills, rather than developing core banking activities. However, as the restructuring of the sector proceeds, foreign interest has gathered momentum.

Consolidation has also taken place in the stateowned banks. Following the crises in 2000 and 2001, two state-owned banks (Emlak and Ziraat) were merged, and all state-owned banking activities were rationalised. State-owned banks nevertheless continue to play an important part in the Turkish banking sector.

\section{Asset structure}

The asset structure of the banking sector has changed significantly since the financial crisis. Increased macroeconomic stability, more stable sources of funding and easier access to working capital have contributed to a gradual restructuring of the banking sector's asset structure. One of the main elements of change has been the shift to core banking activities, which resulted in credit growth to the private sector of around 50\% in 2004 and 40\% in 2005 . Consequently, the share of loans in total assets increased from $26.5 \%$ at the end of 2001 , their lowest level since 2000 , to $37.5 \%$, as of September 2005 (see Table 5.2).

Government securities still dominate the asset side of state-owned banks but not any more in the case of private banks. While government securities still dominate the asset side of the banking sector as a whole, this largely reflects the banking restructuring process and the reimbursement of 'duty losses' incurred by 


\section{Table 5.2 Asset structure of the Turkish banking sector in 2005 I)}

\begin{tabular}{l|c|c|c|}
\hline & $\begin{array}{c}\text { Turkish banking sector } \\
\text { in \% of total assets }\end{array}$ & $\begin{array}{c}\text { State-owned banks } \\
\text { in \% of total assets }\end{array}$ & $\begin{array}{c}\text { Privately owned banks } \\
\text { in \% of total assets }\end{array}$ \\
Cash and central bank balances & 2.8 & 2.7 & 3.2 \\
Due from banks & 6.2 & 5.5 & 5.1 \\
Securities & 39.9 & 57.7 & 33.4 \\
Loans & 37.5 & 23.8 & 42.6 \\
Other assets & 13.6 & 10.3 & 15.7 \\
Reserve deposits & 3.9 & 3.5 & 4.3 \\
Accrued interest and income receivable & 2.6 & 2.5 & 2.8 \\
Property and equipment & 2.5 & 2.1 & 2.9 \\
Subsidiaries (net) & 2.7 & 0.7 & 4.0 \\
Investment and associates & 0.4 & 0.1 & 0.7 \\
Other & 1.5 & 1.4 & 1.0 \\
Total & 100.0 & 100.0 & 100.0 \\
\hline
\end{tabular}

Source: Banks Association of Turkey.

1) As of September.

state-owned banks through government securities. In contrast, the asset side of privately owned banks is dominated by loans, and not by securities.

As banks shift to core banking activities, the maturity of assets has increased. Owing to the increased macroeconomic stability and more stable sources of funding banks have felt more comfortable investing in longer-term assets, sparking a decline in liquidity. Other assets consist mainly of reserve deposits, accrued interest and income receivable, and property and equipment.

In addition, there has been a shift in the currency structure of assets away from foreign currencies. Owing to high inflation rates, and especially during times of distress, Turkish banks preferred foreign-exchange-denominated assets. Following the restructuring of the banking sector, the Turkish lira/foreign exchange composition has altered in favour of assets denominated in local currency. The share of Turkish lira-denominated assets grew from 51\% at the end of 2001 to $66 \%$ by September 2005 .

\section{Liability structure}

The liability structure of the banking sector has also undergone significant changes in the past few years. Increased confidence in the banking sector has led to an overall rise in the volume of deposits. There is, however, a distinction between the state-owned and privately owned banks: while the share of deposits in total liabilities of the privately owned banks has declined, it has increased in total liabilities of the state-owned banks.

However, deposits still have predominantly a short-term maturity. As of September 2005, deposits of up to one month constituted $44 \%$ of total deposits, while deposits of one to three months represented $39 \%$. A notable development is the reduction in the share of foreign exchange deposits, which had declined to $39 \%$ of total deposits by September 2005, down from $60 \%$ at the end of 2001 .

Interbankfunding has decreased for the banking sector as a whole, though it has increased for private banks, reflecting their shift to core banking activities. Interbank funding consists predominantly of funds borrowed from foreign banks and funds provided under repurchase agreements. Funds borrowed from the Central Bank of the Republic of Turkey were negligible by the end of 2005 . For the banking sector as a whole, interbank funding decreased considerably after the 2000 and 2001 crises, from around $25 \%$ of total assets in 2000 to around $15 \%$ in September 2005 (see Table 5.3). For the stateowned banks, the share of interbank funding is substantially lower, but for the privately-owned 


\begin{tabular}{|c|c|c|c|}
\hline & $\begin{array}{c}\text { Turkish banking sector } \\
\text { in } \% \text { of total assets }\end{array}$ & $\begin{array}{l}\text { State-owned banks } \\
\text { in \% of total assets }\end{array}$ & $\begin{array}{c}\text { Privately owned banks } \\
\text { in } \% \text { of total assets }\end{array}$ \\
\hline Deposits & 63.4 & 76.0 & 61.3 \\
\hline Due from banks & 15.3 & 5.1 & 19.7 \\
\hline Shareholders' equity & 13.0 & 9.4 & 12.2 \\
\hline Other liabilities & 8.3 & 9.5 & 6.8 \\
\hline Miscellaneous payables & 2.2 & 1.1 & 2.5 \\
\hline Funds & 1.5 & 4.5 & 0.0 \\
\hline Provisions & 2.0 & 2.2 & 1.8 \\
\hline Other external resources & 1.2 & 0.6 & 1.3 \\
\hline Other & 1.4 & 1.1 & 1.2 \\
\hline Total & 100.0 & 100.0 & 100.0 \\
\hline
\end{tabular}

banks it has in fact risen to close to $20 \%$ of total assets, as increased macroeconomic stability has also made it easier for them to obtain interbank funding through syndication and securitisation loans in the international market. $^{23}$

The restructuring process has also led to increases in the capitalisation of banks. Shareholders' equity has more than doubled since the 2000 and 2001 crises, growing from $7 \%$ of total assets at the end of 2000 to $13 \%$ as of September 2005 (see Table 5.3). Both the state-owned banks and the privately owned banks have been recapitalised, with the latter being asked to increase equity by a total of USD 2.7 billion between 2001 and 2003. This helps to explain why the privately owned banks are significantly better capitalised than the state-owned banks.

There has been a move away from foreign currencies in the currency composition of liabilities. In line with the dedollarisation of the asset side, there has been an increase in the share of liabilities denominated in local currency, from $44 \%$ at the end of 2001 to $63 \%$ as of September 2005.

\section{Banking sector profitability}

Following the crisis, the banking sector has returned to profit since 2002. The crisis years saw very large losses in the banking sector. Since then, profitability has picked up, with return on equity and return on assets standing at $9 \%$ and $1 \%$ for the banking sector as a whole, as of September 2005 (see Table 5.4). Stateowned banks outperformed the privately owned banks in 2003 and 2004, in terms of both return on assets and return on equity, due to their lower levels of capital and their dominant position in the sector, which gives them easy access to relatively cheap funding (deposits).

Profitability has been helped by the maturity structure of the banking sector's assets and liabilities. As interest expenses decreased more rapidly than interest income, net interest income increased for the sector as a whole. This is due to the fact that short-term deposits (0-3 months) are the main source of funding for Turkish banks. Hence, the average maturity of interest rate sensitive liabilities is shorter than that of interest rate sensitive assets. Consequently, any decrease in interest rates has a positive effect on the sector's profitability.

23 Interbank funding played its part during the November 2000 crisis, as one of the main triggers was the emergence of liquidity problems in Demirbank, which, at the time, was the sixth largest privately owned bank. Banks like Demirbank invested increasingly in longer-term investments to compensate for falling interest rates, and hence falling interest rate income. These longer-term investments, however, were financed through short-term funding. When (short-term) interest rates rose, and funding became increasingly expensive, Demirbank was forced to sell government securities at a loss to maintain liquidity. When the main banks realised this, they cut interbank credit lines, and overnight interest rates soared. In December 2000, the Banking Regulation and Supervisory Agency (BRSA) took over Demirbank and transferred it to the Savings Deposit Insurance Fund (SDIF). 
Table 5.4 Profitability of the Turkish banking sector

\begin{tabular}{|c|c|c|c|c|c|c|}
\hline & 2000 & 2001 & 2002 & 2003 & 2004 & 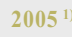 \\
\hline $\begin{array}{l}\text { Total operating income in } \% \\
\text { of which in } \% \text { of total operating income: }\end{array}$ & 100.0 & 100.0 & 100.0 & 100.0 & 100.0 & 100.0 \\
\hline net interest income & 76.9 & 158.3 & 64.3 & 48.1 & 67.2 & 65.5 \\
\hline net fees and commissions income & 15.1 & 14.8 & 11.1 & 11.5 & 15.1 & 17.1 \\
\hline net trading income & -29.4 & -90.1 & 4.5 & 28.5 & 8.8 & 7.9 \\
\hline other operating income & 37.4 & 17.0 & 20.1 & 12.0 & 9.0 & 9.5 \\
\hline $\begin{array}{l}\text { Total operating expenses as } \% \text { of total operating income } \\
\text { of which in } \% \text { of total operating income: }\end{array}$ & 141.4 & 148.8 & 73.5 & 60.1 & 55.8 & 70.1 \\
\hline provisions for NPLs and other receivables & 25.0 & 76.7 & 24.7 & 14.6 & 14.0 & 19.9 \\
\hline personnel expenses & 36.5 & n.a. & 18.0 & 17.1 & 17.7 & n.a. \\
\hline other operating expenses & 80.0 & 72.1 & 30.8 & 28.5 & 24.2 & 50.2 \\
\hline Return on assets & -3.0 & -5.7 & 1.1 & 2.2 & 2.1 & 1.1 \\
\hline Return on equity & -62.4 & -58.4 & 9.2 & 15.8 & 14.0 & 8.6 \\
\hline
\end{tabular}

Source: Banks Association of Turkey.

1) As of September.

Interest earned on securities remains the largest source of banks' income, but interest income from loans and other sources have nevertheless increased. Net interest income is the main source of income in the Turkish banking sector, mainly reflecting interest income from banks' securities portfolios and interest income from loans. Interest expenses are dominated by interests paid on deposits. Interest income increased slightly in nominal terms from 2003 to 2005 , while interest expenses declined. As a result, net interest income increased both in nominal and relative terms. At the same time, the share of non-interest income in total operating income increased from around $20 \%$ at the end of 1999 to more than 30\% in September 2005 mainly due to the rise in fees and commissions income linked inter alia to the development of the credit card business, particularly for privately owned banks.

The restructuring of the banking sector has also led to lower operating costs. Total operating expenses over total assets have decreased significantly since 2001 due, among other things, to decreasing provisioning needs for non-performing loans (NPLs). Especially during 2001, provisions for NPLs ballooned to $76.7 \%$ of total operating income (see Table 5.4) as a result of the crisis.
Following the 2000 and 2001 crises, the stateowned banks closed branches and made significant cuts in personnel. While both their number of branches and personnel have increased again, they are still far below their pre-crisis levels. The privately owned banks, however, have continued opening new branches and have substantially increased their number of personnel, in line with the growth in core banking activities, and especially consumer lending.

\section{RISKS AND SHOCK-ABSORBING CAPACITIES}

\section{Credit risk}

In line with the recent shift to core banking activities, the credit risk linked to the private sector has risen. The increase in the share of loans in total assets has added another dimension to the credit risk borne by the banking sector, which was traditionally overly dependent on government securities for revenue generation. Credit demand stems from large corporations, SMEs and consumers, as around $95 \%$ of loans are extended to the private sector. The latter two categories, however, have historically played only a marginal role in banks' loan portfolios. Only since 2003 has consumer lending picked up substantially. 
This rapid increase in consumer lending may potentially impact the quality of the loan portfolio. Credit cards and consumer loans have accounted for $31.9 \%$ of total lending as of September 2005, higher than loans for working capital $(14.5 \%)$, and export loans $(12.1 \%)$. This is not surprising given the marketing of credit cards over the past few years. The number of credit cards issued was slightly under 27 million at the end of 2004. With a population of around 70 million, this amounts to around 386 credit cards per 1,000 persons. Such high growth figures, however, are not sustainable and the credit card segment seems to have become saturated.

New areas of lending, such as mortgages, may also see fast growth in the future. With the rapid decline in inflation and a decrease in interest rates, mortgage lending has now become a real option. The Turkish mortgage market is still very small, and represented only $0.2 \%$ of GDP in 2003 and $0.6 \%$ in 2004. Commercial banks expect this to have increased to $6 \%$ by the end

\section{Table 5.5 Turkey: Selected banking sector stability indicators}

\begin{tabular}{|c|c|c|c|c|c|c|}
\hline & 2000 & 2001 & 2002 & 2003 & 2004 & $2005 / Q 3$ \\
\hline \multicolumn{7}{|l|}{ Risks } \\
\hline \multicolumn{7}{|l|}{ Credit risk } \\
\hline Domestic credit growth (annual percentage change) ${ }^{1)}$ & 63.9 & 100.6 & 29.0 & 18.3 & 21.2 & 16.1 \\
\hline Real domestic credit growth (annual percentage change) ${ }^{2)}$ & 24.9 & 32.0 & -0.8 & 2.2 & 11.8 & 8.1 \\
\hline Credit growth to the private sector (annual percentage change) ${ }^{3)}$ & 72.1 & 22.7 & 10.2 & 44.6 & 52.8 & 41.3 \\
\hline Real credit growth to the private sector (annual percentage change) ${ }^{2)}$ & 33.1 & -45.8 & -19.6 & 28.5 & 43.4 & 33.3 \\
\hline Credit growth to households (annual percentage change) ${ }^{4}$ & 208.4 & -27.9 & 34.4 & 95.8 & 103.4 & 69.0 \\
\hline Growth of consumer housing loans (annual percentage change) & n.a. & n.a. & n.a. & 90.2 & 297.0 & \\
\hline Non-performing loans (in \% of total loans) & 11.1 & 25.2 & 17.6 & 11.5 & 6.0 & 5.4 \\
\hline Past due loans (in \% of total assets) & 3.8 & 4.3 & 4.9 & 3.5 & 2.1 & \\
\hline Share of foreign currency loans in total loans (in \%) & 43.4 & 58.7 & 57.6 & 46.3 & 36.5 & 30.9 \\
\hline Share of foreign currency deposits in total deposits (in \%) & 46.1 & 59.7 & 57.9 & 49.3 & 44.8 & 39.3 \\
\hline Growth of foreign liabilities (annual percentage change) & 58.0 & -7.0 & 9.7 & 20.7 & 37.3 & 51.7 \\
\hline Share of foreign liabilities in total liabilities & 26.5 & 20.7 & 18.5 & 15.3 & 15.0 & 17.8 \\
\hline \multicolumn{7}{|l|}{ Market risk } \\
\hline \multicolumn{7}{|l|}{ Interest rate risk } \\
\hline Net interest income in $\%$ of average assets & & 11.0 & 6.4 & 4.5 & 6.2 & \\
\hline Net non-interest income in $\%$ of average assets & & 4.0 & 4.0 & 3.2 & 2.9 & \\
\hline \multicolumn{7}{|l|}{ Forex risk } \\
\hline FX assets (as a percentage of FX liabilities) & 75.9 & 88.2 & 91.9 & 90.7 & 91.7 & 90.7 \\
\hline FX assets (as a percentage of total assets) & 35.3 & 49.2 & 46.4 & 39.3 & 36.8 & 33.7 \\
\hline FX liabilities (as a percentage of total liabilities) & 46.5 & 55.8 & 50.4 & 43.3 & 40.1 & 37.2 \\
\hline Open FX position in $\%$ of total balance sheet assets & -3.6 & -0.1 & -0.4 & 0.0 & -0.1 & \\
\hline \multicolumn{7}{|l|}{ Liquidity risk } \\
\hline Liquid assets (as a percentage of total assets) & 32.2 & 31.0 & 34.3 & 38.8 & 37.4 & 39.1 \\
\hline Ratio of loans to deposits ${ }^{4)}$ & & & 35.5 & 42.6 & 52.0 & 61.7 \\
\hline Liquid assets (as a percentage of short-term liabilities) & n.a. & 81.1 & 75.1 & 80.5 & 84.3 & 82.7 \\
\hline \multicolumn{7}{|l|}{ Shock-absorbing factors } \\
\hline Net interest margin between loans and deposits (percentage points) & 4.8 & 10.5 & 2.1 & 0.8 & 5.7 & \\
\hline Loan loss provisions (as a percentage of non-performing loans) & 63.1 & 49.0 & 64.2 & 88.5 & 88.1 & 89.6 \\
\hline Capital adequacy ratio & & 21.0 & 25.6 & 31.0 & 28.8 & 23.3 \\
\hline \multicolumn{7}{|l|}{ Memo } \\
\hline Number of banks (foreign-owned) & 79 & $61(15)$ & $54(15)$ & $50(13)$ & $48(13)$ & $47(13)$ \\
\hline Asset share of foreign-owned banks (in \%) & 3 & 3 & 3 & 3 & 3 & 6 \\
\hline $\begin{array}{l}\text { Sources: CBRT, BRSA, Banks Association of Turkey and IMF. } \\
\text { 1) Domestic credit from banking survey. } \\
\text { 2) Deflated using CPI. } \\
\text { 3) Claims on private sector by deposit money banks. } \\
\text { 4) Latest value: } 2005 / \mathrm{H} 1\end{array}$ & & & & & & \\
\hline
\end{tabular}


of 2008. In response to these developments, a new law on mortgage lending is under consideration.

Historically, NPLs have been a key problem for the Turkish banking sector. In the past, it faced three kinds of problem with NPLs, namely those linked to related party lending, those of stateowned banks and those of privately-owned banks due to the economic downturn following the 2000 and 2001 crises. The restructuring programme that followed the crises addressed these issues. Related party lending was restricted by a new regulation, and the state-owned banks were recapitalised to improve the provisioning of NPLs. The NPLs of the privately owned banks were addressed as part of the "Istanbul Approach", a voluntary framework aimed at facilitating the debt restructuring of mainly large corporate borrowers. As a result, the overall ratio of NPLs decreased substantially to around 5\% of gross loans in 2005 (as of September) compared with $25 \%$ of total loans in 2001. At the same time, loan loss provisions increased over the same period from $49 \%$ to almost $90 \%$ of non-performing loans.

The development of NPL ratios on new lending signals some potential for a future deterioration in credit quality. The NPL ratio for consumer loans remained stable at less than $1 \%$ at the end of 2004, but that ratio for credit cards increased rapidly in early 2005 . This is not insignificant given that NPLs linked to credit cards represented $93 \%$ of total NPLs in consumer and credit card loans at the end of 2004. While the overall picture in terms of NPLs seems to be giving no direct cause for concern, given the relatively low levels of NPLs and the adequate provision coverage, they could increase again in the future if the indebtedness of households increases.

\section{Market and liquidity risk}

Interest rate risk is the dominant factor in market risk, followed by exchange rate risk. Owing to the continuing decline in interest rates, Turkish banks prefer short-term funding. Indeed, since 2003, the cost of funding has decreased substantially, and banks expect this trend to continue. At the same time, as discussed above, the maturity of loans is increasing. Consequently, there is a maturity mismatch which is still rising. Fixed interest rate loans have also increased in the past few years to $86 \%$ of total loans at the end of 2004. Moreover, interest income has been declining relative to non-interest income (see Table 5.4). This leaves the Turkish banking sector vulnerable to an adverse interest rate shock, especially when the spread between average lending and funding rates becomes smaller.

Since the losses after the floating of the Turkish lira, banks' exposure to exchange rate risk has been greatly reduced. Prior to the 2000-01 crisis, the banking sector viewed the exchange rate risk as limited, as the lira was pegged and the Central Bank of the Republic of Turkey intervened to stabilise the exchange rate. Consequently, many banks borrowed in foreign exchange and lent in domestic currency at high rates (including to the Treasury), leading to large open positions. When the lira was floated, the sector incurred significant foreign exchange losses. The subsequent gradual restructuring of the banking sector has led to a decrease in the exchange rate risk borne by the sector and, by the end of 2004, the exchange rate positions in the banking sector were broadly in equilibrium.

Liquidity is ample and liquidity ratios appear to be improving. Liquid assets have been increasing both as a percentage of total assets and as a percentage of short-term liabilities. Cash and cash equivalent assets stood at around $8 \%$ of total assets in September 2005. The ratio of assets to liabilities based on remaining maturities, however, has declined, due to banks' preference for short-term funding in the light of declining interest rates and increasing longerterm lending because of macroeconomic stability.

\section{Shock-absorbing factors}

The Turkish banking sector has increased its shock absorption capacity since the 2000 and 
2001 crises. Profitability levels appear to be adequate and more sustainable in the long run, in contrast to the profits of the $1990 \mathrm{~s}$ that stemmed from the government's unsustainable financing needs. The capital adequacy ratio stood at 23\% as of September 2005.

Stress tests suggest that banks would be able to cope with a deterioration in the quality of their loan portfolio. Calculations by the Central Bank of the Republic of Turkey suggest that an increase in the NPL ratio from its current level of around $5 \%$ to $21 \%$ of total loans would reduce the capital adequacy ratio to $18.8 \%$, still comfortably above the minimum level required. Under this scenario, all new NPLs are deemed to fall in the $100 \%$ risk weight group. Hence, the scenario analysis shows that the sector's shareholders' equity levels are sufficient to cover credit risk.

Progress has been made in strengthening the regulatory and supervisory framework. The authorities responsible for supervising and regulating the financial sector are the Banking Regulation and Supervision Agency (BRSA), the Under-Secretariat of the Treasury under the Prime Ministry of the Republic of Turkey and the Capital Markets Board of Turkey (CMB). Following the 2000 and 2001 crises, the BRSA overhauled the regulatory and supervisory framework, bringing it more up to date with best practices. As a result, supervision has improved considerably, so that some of the main problems leading to the 2000 and 2001 crises should be able to be avoided in the future.

\subsection{SUMMARY AND CONCLUSIONS}

A key challenge for Turkey is to reduce the current account deficit that has resulted from strong domestic demand, capital inflows and the (real) appreciation of the lira. This is particularly important given the unfavourable maturity structure of external debt. In addition, the level and the structure of public debt still constitute a source of vulnerability, highlighting the importance of continued strict adherence to sound fiscal policies.
The Turkish financial sector is showing signs of increasing confidence: the portion of assets and liabilities in local currency is rising and there is growing foreign interest in Turkish banks, although the share of assets held by foreignowned banks is still comparatively small. In addition, banks are increasingly shifting from simply transforming deposits into government security holdings to core banking activities, i.e. lending to the corporate and household sectors. Consequently, credit has been growing rapidly and the maturity of assets has been lengthening.

Credit risk is rising due to strong credit growth, particularly in consumer lending and credit cards. Moreover, new products are being introduced and hence creating potential for a build-up of non-performing loans. Interest rate risk is also rising, as declining interest rates are giving banks an incentive to continue to borrow short-term, exacerbating maturity mismatches. In addition, market risk related to Treasury bill holdings is still significant. At the same time, the sector has increased its shock absorption capacity in terms of profitability and capitalisation. 


\section{SPECIAL FEATURE I: FINANCIAL MARKETS AND NON-BANK FINANCIAL INSTITUTIONS}

Financial markets and non-bank financial institutions are still relatively underdeveloped in the acceding and candidate countries. Although the banking sector remains the main pillar for financial intermediation in these countries, in recent years, non-bank financial intermediation has increased substantially, via non-bank financial institutions and financial markets. This increase, which started from initially low levels, can be attributed to, among other things, macroeconomic stabilisation, a favourable external environment and structural changes within the sectors themselves. Over the next few years, the strengthening of candidate countries' convergence efforts with the EU economies is likely to have a positive effect on the non-bank financial sectors in the acceding and candidate countries.

\section{NON-BANK FINANCIAL INSTITUTIONS PLAY A SMALL BUT GROWING ROLE}

Although the non-bank financial sectors of the acceding and candidate countries are still smaller than those of Western European countries, they have developed rapidly in recent years. In 2005 the assets of the non-bank financial institutions in the acceding and candidate countries was about $10-15 \%$ of total financial sector assets (see Table SF1.1), compared with only $7-10 \%$ in $2001 / 02$. Given the growth of the banking sector, this increase is particularly noteworthy. Efforts by regulators to curb banking sector credit growth may have shifted some lending to non-bank financial institutions, particularly leasing companies.

Given the limited size of the non-bank financial sector, it is unlikely to have a determinant effect on the stability of the financial system. This is particularly the case for Bulgaria, which has the smallest non-bank financial sector. However, the non-bank financial sector in these countries is generally less regulated than the banking sector, and policy-makers should therefore be vigilant. To prevent regulatory arbitrage, the standards for supervision and regulation of non-bank financial institutions should be kept in line with those of the banking sector. ${ }^{24}$

24 In Romania, a new law has become effective in January 2006, establishing reporting requirements for non-bank financial institutions. While most of the application norms have been already published, the de facto reporting did not start yet.

\begin{tabular}{|c|c|c|c|c|}
\hline & Bulgaria & Croatia $^{1)}$ & Romania & Turkey \\
\hline \multicolumn{5}{|l|}{ Share of total assets (in \%) } \\
\hline Banks & 85.8 & 81.6 & 84.2 & 86.8 \\
\hline Investment funds & - & 2.2 & 0.3 & $6.3^{3)}$ \\
\hline Financial investment companies & - & - & $3.3^{2)}$ & 0.5 \\
\hline Insurance companies & 3.3 & 5.2 & 3.5 & 2.8 \\
\hline Pension funds & 2.9 & 2.9 & - & 0.3 \\
\hline Leasing companies & 4.3 & 5.7 & 6.8 & 1.2 \\
\hline Other & 3.7 & 2.4 & 1.8 & 2.1 \\
\hline Total & 100.0 & 100.0 & 100.0 & 100.0 \\
\hline Total assets (EUR billions) & 19.6 & 36.2 & 42.1 & 294.9 \\
\hline Memo: GDP (EUR billions) & 21.4 & 27.7 & 79.3 & 286.7 \\
\hline Total assets' share of GDP (in \%) & 91.3 & 130.7 & 53.2 & 102.7 \\
\hline Bank assets' share of GDP (in \%) & 78.3 & 106.6 & 44.8 & 89.0 \\
\hline \multicolumn{5}{|c|}{$\begin{array}{l}\text { Sources: IMF, Bulgarian National Bank, National Bank of Romania, Central Bank of the Republic of Turkey, Pre-Accession Economic } \\
\text { Program, Croatia, December 2005, ECB. } \\
\text { 1) Data is for end-2004. } \\
\text { 2) Investment funds" assets, including the funds administrated by Assets Management Company which are not members of "The National } \\
\text { Union for Collective Investment". } \\
\text { 3) Mutual funds. }\end{array}$} \\
\hline
\end{tabular}




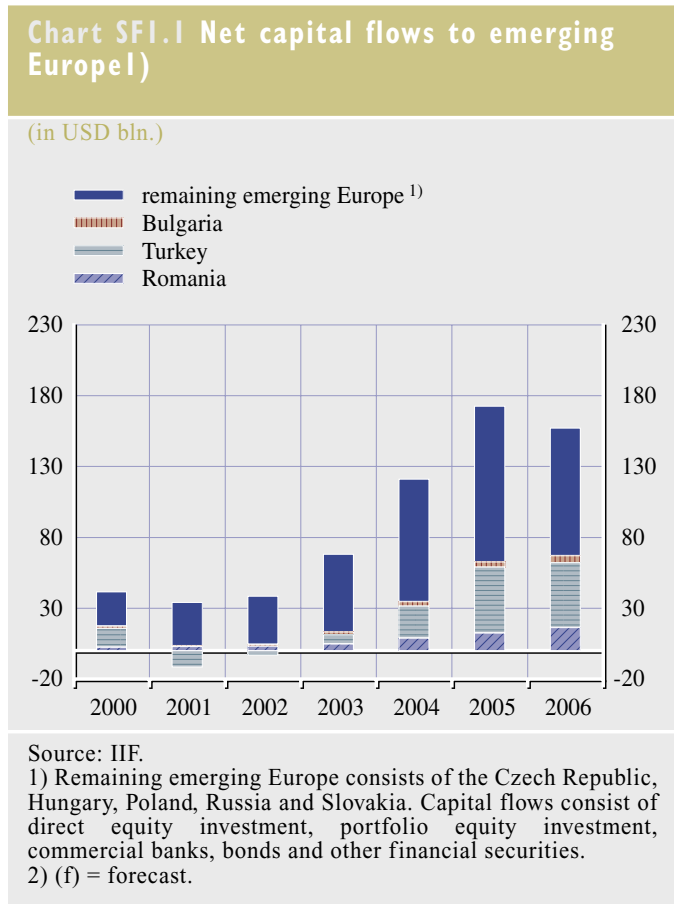

\section{DEVELOPMENTS IN BOND MARKETS}

There has been a large flow of foreign capital into emerging markets in recent years, including into the acceding and candidate countries (see Chart SF1.1). The Institute of International Finance (IIF) estimates that net bond inflows accounted for around one-quarter of total net inflows into Romania in 2005 and around onethird of inflows into Turkey and Bulgaria. This partly reflects low nominal interest rates in mature markets and an associated reduction in risk aversion by investors. The increase in nonresident holdings of Turkish government bonds is notable, particularly in the domestic bond market, where the share of non-resident holdings increased from 7\% at the end of 2003 to around $13 \%$ by the third quarter of 2005 .

Debt markets in candidate countries have also benefited from a series of sovereign ratings upgrades and a favourable interest rate climate. Bulgaria and Romania were granted investmentgrade status by Standard \& Poor's in 2005 (see Chart SF 1.2), which has broadened their foreign investor base significantly. Together with the

\section{Chart SFI.2 Sovereign credit ratings}

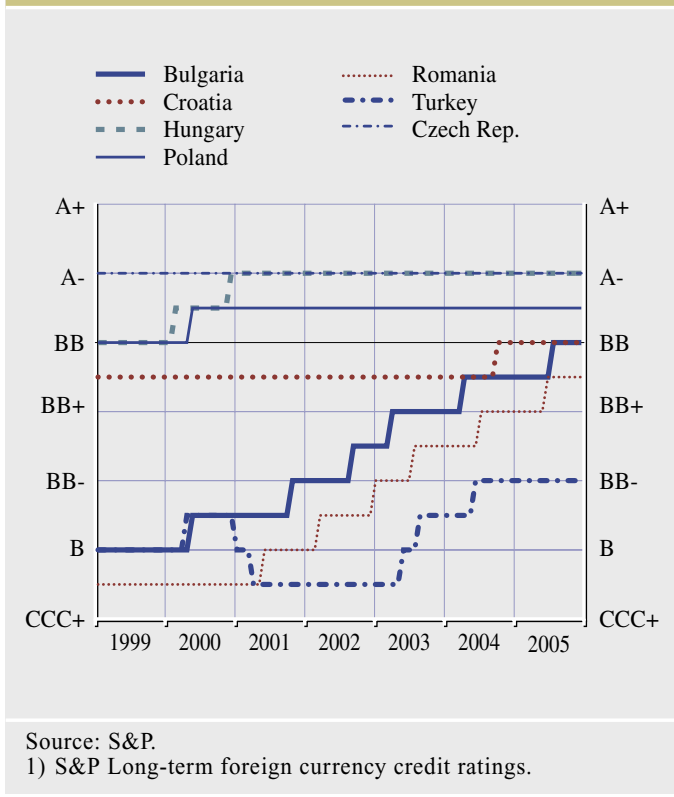

growing role of institutional investors within the acceding and candidate countries, this has enhanced the growth potential of the bond markets. Turkey and, to a lesser extent, Croatia have taken advantage of the favourable

\section{Chart SFI.3 Euro EMBIG government bond spreads}

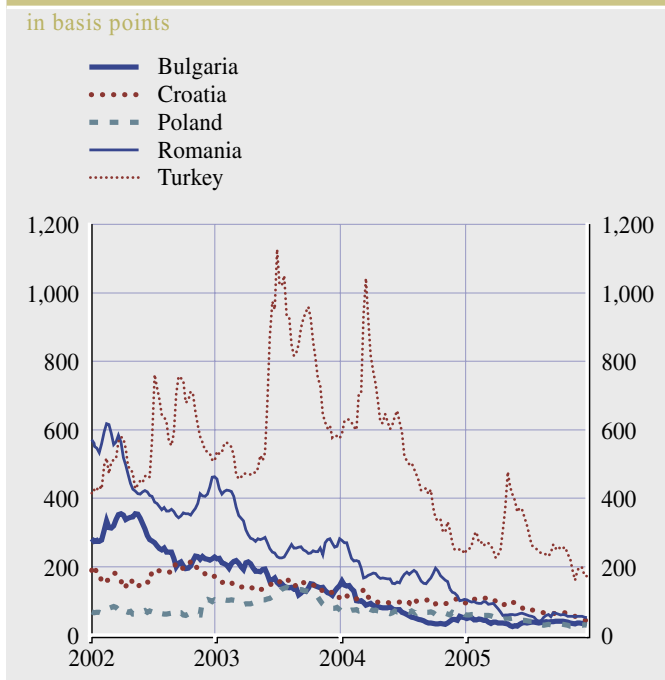

Source: JP Morgan via Bloomberg. 


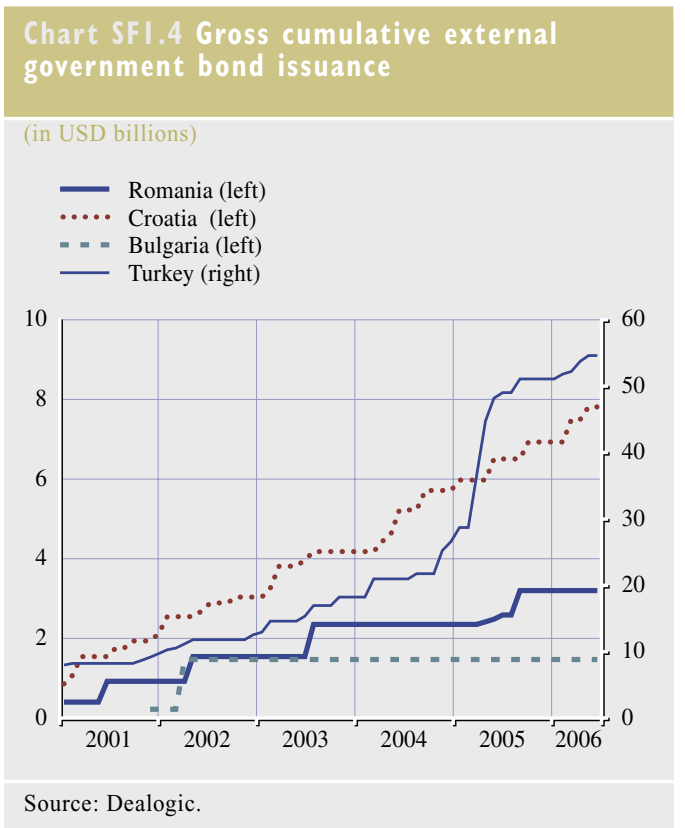

environment and declining interest rates (see Chart SF1.3) to increase their external bond issuance (see Chart SF1.4). However, gross external issuance in Romania and Bulgaria has remained flat, despite ratings upgrades and a broadening of the investor base. Since 2004 the private sector has also increased its borrowing from abroad through bond finance, particularly in Turkey and Bulgaria, albeit from a very low base.

The relative sizes of the external sovereign bond markets in the acceding and candidate countries are comparable with those of the new Member States (around 5-15\% of GDP, see Chart SF 1.5). By contrast, domestic bond markets in the

\begin{tabular}{|c|c|c|c|c|}
\hline \multicolumn{5}{|c|}{ (in USD millions) } \\
\hline & Bulgaria & Croatia & Romania ${ }^{1)}$ & Turkey \\
\hline 2001 & 0.5 & 85.2 & 0.0 & $37,297.0$ \\
\hline 2002 & 10.1 & 616.6 & 0.2 & $67,256.4$ \\
\hline 2003 & 41.1 & $1,617.8$ & 5.1 & $144,421.6$ \\
\hline 2004 & 49.8 & $2,308.5$ & 28.0 & $136,742.6$ \\
\hline Mid-2005 & 89.3 & $1,973.4$ & 35.7 & $201,028.8$ \\
\hline
\end{tabular}

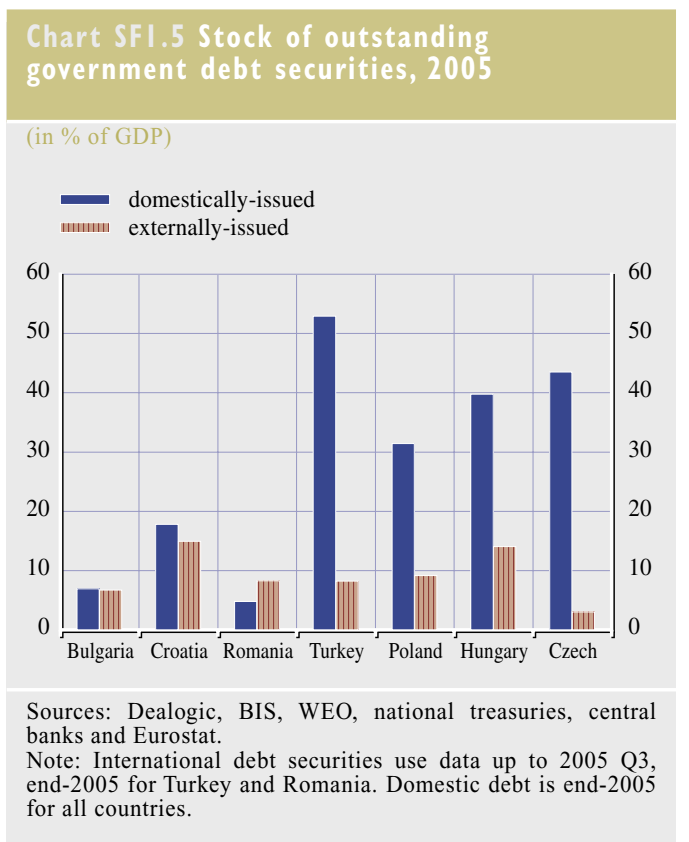

acceding and candidate countries (except Turkey) are smaller and less developed than those of the new Member States. Although the size of the domestic bond markets remains relatively small in Romania, Croatia and Bulgaria, the significant increase in secondary market activity over the past few years is indicative of financial deepening (see Table SF1.2). Since 2001 total trading volume of domestic bonds has increased five-fold in Turkey, 23-fold in Croatia, 179-fold in Bulgaria. Convergence with the EU should support further growth of domestic bond markets. The demand side also has growth potential as institutional investors are expected to play a greater role, as with the further development of the non-bank financial sector.

\section{DEVELOPMENTS IN STOCK MARKETS}

Stock markets have benefited from macroeconomic stabilisation and improvements in terms of regulation and structure. Relatively strong GDP growth rates and better prospects for EU accession have sustained stock market performance in the acceding and candidate countries (see Charts SF1.6 and SF1.7). Equity 


\section{Chart SFI.6 Development in stock indices}

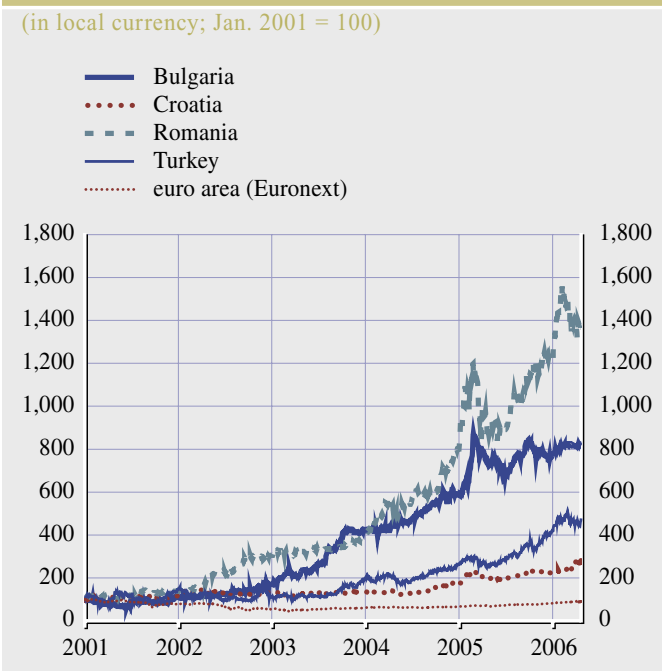

Source: Ecowin.
Chart SFI.7 Stock markets in selected new Member States

\section{$($ Jan. $2001=100)$ \\ - Czech Republic \\ ..... Hungary \\ - . - Poland}

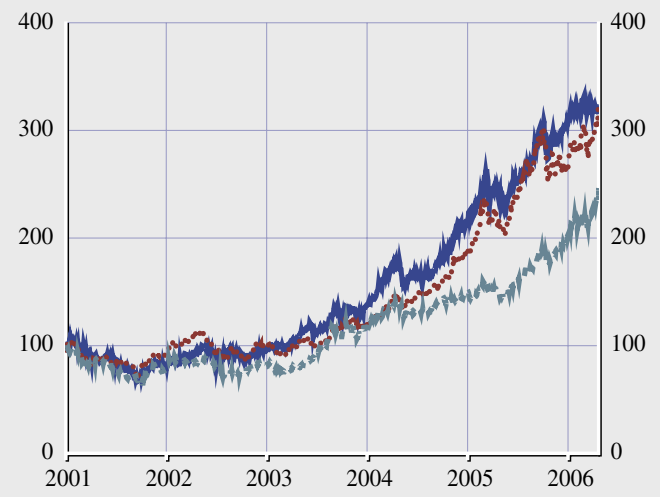

Source: Ecowin.

performance was more mixed. The Turkish stock market has also exhibited strong index growth in recent years. Valuation effects have

Romania during 2003-04, with stock market indices doubling, whereas in 2005 their

\section{Table SFI.3 Selected stock market indicators}

\begin{tabular}{|c|c|c|c|c|c|c|}
\hline & 2000 & 2001 & 2002 & 2003 & 2004 & $2005^{3)}$ \\
\hline \multicolumn{7}{|l|}{ Bulgaria } \\
\hline Number of companies & 503 & 399 & 354 & 338 & 371 & 331 \\
\hline Market capitalisation (in USD millions) & 573 & 507 & 713 & 1,734 & 2,801 & 5,912 \\
\hline Market capitalisation (in \% of GDP) & 4.6 & 3.7 & 4.6 & 8.7 & 11.7 & 22.9 \\
\hline Total volume (in USD millions) & 58 & 70 & 155 & 154 & 466 & $\ldots$ \\
\hline \multicolumn{7}{|l|}{ Croatia $^{1)}$} \\
\hline Number of companies & 61 & 45 & 71 & 175 & 180 & $\ldots$ \\
\hline Market capitalisation (in USD millions) & 2,712 & 3,068 & 3,805 & 6,069 & 10,952 & 12,837 \\
\hline Market capitalisation (in \% of GDP) & 14.7 & 15.5 & 16.7 & 21.1 & 31.9 & 33.9 \\
\hline Total volume (in USD millions) & 185 & 116 & 145 & 224 & 294 & $\ldots$ \\
\hline \multicolumn{7}{|l|}{ Romania $^{2)}$} \\
\hline Number of companies & 114 & 65 & 65 & 62 & 60 & 64 \\
\hline Market capitalisation (in USD millions) & 416 & 1,229 & 2,718 & 3,710 & 11,938 & 18,185 \\
\hline Market capitalisation (in \% of GDP) & 1.3 & 3.3 & 6 & 6.2 & 13.9 & 19.5 \\
\hline Total volume (in USD millions) & 87 & 132 & 214 & 302 & 748 & 2673 \\
\hline \multicolumn{7}{|l|}{ Turkey } \\
\hline Number of companies & 315 & 310 & 288 & 285 & & $\ldots$ \\
\hline Market capitalisation (in USD millions) & 69,507 & 47,689 & 34,402 & 69,002 & 98,073 & 161,537 \\
\hline Market capitalisation (in \% of GDP) & 35.1 & 33.3 & 18.8 & 28.6 & 32.4 & 45.7 \\
\hline Total volume (in USD millions) & 181,934 & 80,400 & 70,756 & 100,165 & 148,506 & $\ldots$ \\
\hline
\end{tabular}

Sources: Federation of Euro-Asian Stock Exchanges, European Bank for Reconstruction and Development, IMF and national central banks.

1) Zagreb Stock Exchange only. The market capitalisation of the stock exchange in Varazdin, which is not included, is around $35 \%$ of Zagreb's.

2) Bucharest Stock Exchange (BSE) only. The market capitalisation of the RASDAQ stock exchange, which is not included, is around $20 \%$ of BSE's. In November 2005 the two stock exchanges decided to merge, and accordingly the RASDAQ dissolves into BSE.

3) Data is for 2005 Q2 only. 
led to higher stock market capitalisation, which in the second quarter of 2005 accounted for between $19.5 \%$ of GDP in Romania and $45.7 \%$ of GDP in Turkey (see Table SF1.3). In Bulgaria, Croatia and Romania, market capitalisation has risen steadily, more than doubling since 2000. In Turkey stock market capitalisation has now returned to levels not seen since the 2001 financial crisis. In all four countries, stock market capitalisation is catching up with the new Member States, which have an average stock market capitalisation of just above $40 \%$ of GDP, but remains below the euro area average of $70 \%$ of GDP.

As well as being small, stock markets in the acceding and candidate countries have limited trading. This relatively minimal participation hinders substantial increases in market activity, and consequently a significant part of the stocks are not actively traded. Although the volume of annual trading has more than doubled in Bulgaria, Croatia and Romania since 2002, it is still significantly lower (about 1-2\% of GDP in 2004) than in other European stock exchanges. In Turkey the volume of annual trading is significantly higher, accounting for almost $50 \%$ of GDP.

Developments in Bulgaria and Romania are closely linked to the privatisation of stateowned companies, as their listing has led to increased liquidity and market capitalisation.

Stock markets still play a relatively small role because of their comparatively short history and the role of foreign direct investment. Stock exchanges were not established in Bulgaria, Croatia and Romania until the 1990s. Moreover, the inflow of FDI, which is often an alternative to domestic financing, may account for the relatively limited role of stock markets in these countries. This is especially the case for Bulgaria and Romania, where the annual inflow of FDI was around $8-10 \%$ of GDP in 2004. FDI is much less significant in Turkey and accounted for only $1 \%$ of GDP in 2004.

\section{SPECIAL FEATURE 2: THE ROLE OF FOREIGN} BANKS

Foreign banks play a key role in providing finance to the acceding and candidate countries. As Chart SF2.1 indicates, the foreign bank penetration in Bulgaria, Croatia and Romania, as measured by the amount of foreign claims held by major international banks on these countries, was rather low during 1990s, but has increased substantially over the last five years. This development is similar to that of the eight new Member States of Central and Eastern Europe (NMS-8), albeit with some lag. ${ }^{25}$ In absolute terms, the involvement of foreign banks has traditionally been somewhat higher in Turkey, where the recent upward trend has also been notable.

Foreign credit provision plays an important role in all four countries but the pattern of

25 Foreign claims cover financial claims reported to the BIS by domestic bank head offices in 27 major banking centres, including the exposures of their foreign affiliates, and are collected on a worldwide consolidated basis with inter-office positions being netted out. The claims include deposits with and loans and advances to banks and non-banks, holdings of securities and participations.

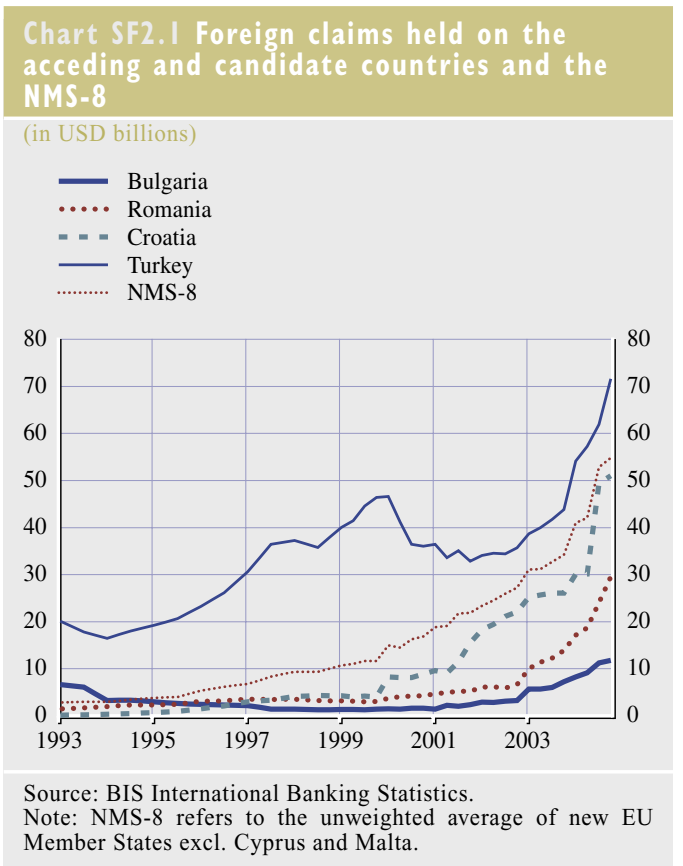




\section{Table SF2.I Composition of foreign claims}

\begin{tabular}{|c|c|c|c|c|c|c|}
\hline \multicolumn{7}{|c|}{ (in USD billions) } \\
\hline & \multicolumn{2}{|c|}{ Total foreign claims } & \multicolumn{2}{|c|}{ International claims } & \multicolumn{2}{|c|}{ Local claims } \\
\hline & 1996 & 2004 & 1996 & 2004 & 1996 & 2004 \\
\hline Bulgaria & 2.4 & 8.3 & 2.4 & 5.6 & 0.0 & 2.6 \\
\hline Romania & 3.1 & 17.2 & 3.0 & 13.2 & 0.1 & 4.0 \\
\hline Croatia & 1.5 & 30.1 & 1.5 & 19.3 & 0.0 & 10.8 \\
\hline Turkey & 23.3 & 54.1 & 22.6 & 50.2 & 0.6 & 3.9 \\
\hline NMS-8 & 5.4 & 41.0 & 4.2 & 19.9 & 1.1 & 21.1 \\
\hline
\end{tabular}

Source: BIS International Banking Statistics.

credit provision by internationally active banks differs. In absolute terms, foreign claims have risen rapidly in the four countries (see Table SF2.1). Total foreign claims as a percentage of GDP has also risen substantially in all the four countries, but (with the exception of Croatia) still remains below the levels seen in the NMS8 (see Table SF2.2). Croatia stands out in terms of the level of foreign involvement, but, in terms of the channels of foreign involvement, Turkey is the exception.

Banks can provide credit to other countries directly via the cross-border channel or indirectly through subsidiaries or branches. The decomposition of foreign claims into international claims and local claims by foreign affiliates (see Table SF2.1) gives an indication of the relative importance of these channels. As local claims only include local currency loans made by foreign subsidiaries and branches, it underestimates the importance of this channel. Conversely, international claims include foreign currency loans made through foreign subsidiaries and branches, which means that the statistics overestimate this channel.

In Turkey most foreign claims go through the cross-border channel. This reflects the different post-crisis strategies that the countries have chosen with respect to privatisation. One possible implication may be that, because of less local involvement, foreign lending in Turkey may be more volatile than in the other countries.

In Bulgaria, Romania and Croatia, the increase in foreign claims has been mainly due to the entry offoreign banks into the domestic markets. Table SF 2.3 shows that while the number of all banks has declined somewhat over the last five years in the acceding and candidate countries and the NMS-8, the number of foreign-owned banks has increased, except in Turkey. This reflects the ongoing new entries of foreign entities into the domestic banking sector and the subsequent consolidation of the sector.

\section{Table SF2.2 Foreign claims}

\begin{tabular}{|c|c|c|c|c|}
\hline & \multicolumn{2}{|c|}{$\begin{array}{l}\text { Total foreign claims } \\
\text { as \% of GDP }\end{array}$} & \multicolumn{2}{|c|}{$\begin{array}{l}\text { Local claims by foreign banks } \\
\text { as } \% \text { of total foreign claims }\end{array}$} \\
\hline Bulgaria & 24.8 & 34.4 & 0.6 & 31.8 \\
\hline Romania & 8.8 & 23.4 & 2.4 & 23.1 \\
\hline Croatia & 7.6 & 87.8 & 0.0 & 35.8 \\
\hline Turkey & 12.6 & 18.2 & 2.7 & 7.1 \\
\hline NMS-8 & 11.2 & 65.2 & 10.1 & 38.3 \\
\hline
\end{tabular}

Sources: BIS International Banking Statistics and IMF International Financial Statistics. 
Table SF2.3 Foreign ownership of banks

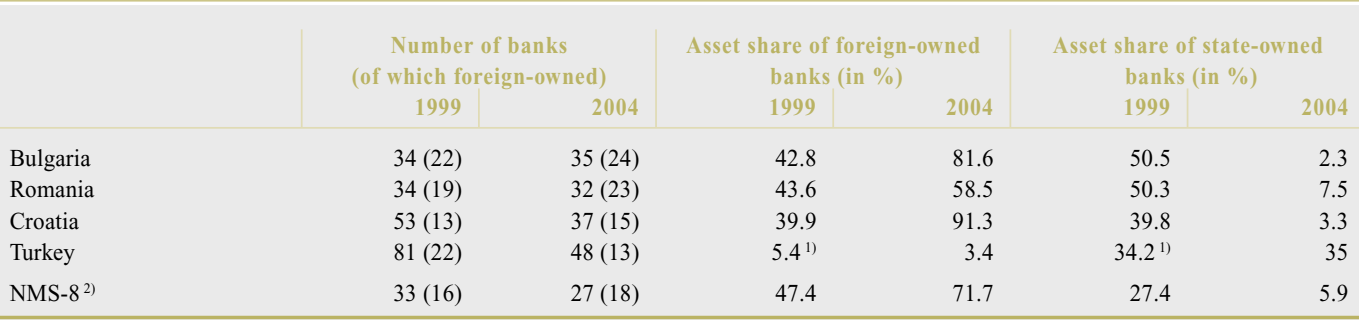

Sources: EBRD Transition Report 2005, national regulatory authorities, Walko (2004) and Walko and Reininger (2005).

1) As of end-2000

2) Unweighted average.

In the first half of the 1990s, foreign banks usually entered Central and Eastern European banking markets via greenfield investment, e.g. by establishing a branch or subsidiary. Towards the end of the 1990s, and especially over the last five years, the most usual way of entry has been to acquire local banks through privatisation. Moreover, some of the greenfield-based subsidiaries and branches of foreign banks later participated in state bank privatisations. As a result, the share of foreign ownership of banks has increased considerably, reaching values of around $80-90 \% .{ }^{26}$ Table SF2.3 shows this trend, with the increase in privatisations corresponding to the decrease in the share of state-owned

\section{Chart SF2.2 Foreign ownership of banks versus loan portfolio quality}

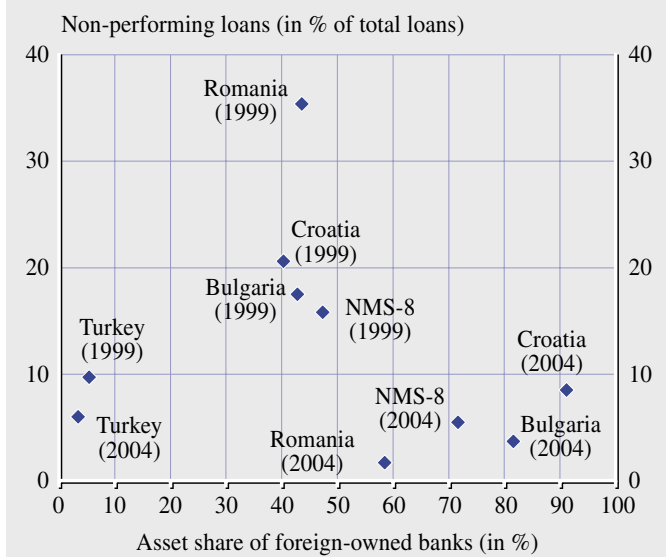

Sources: EBRD Transition Report 2005 and national regulatory authorities.

Note: Asset share for Turkey as of 2000 and 2004 banks. By contrast, Turkey's banking sector is largely domestic-owned, with a significant share of state-owned banks of around $35 \%{ }^{27}$

Both academic literature and practical experience have highlighted the significant benefits of foreign banks' involvement in transition countries. These benefits include increased competition in the banking sector, better access of corporations and households to external finance, risk management, greater efficiency, corporate governance, and overall stability of the sector. ${ }^{28}$ Given the typically high capitalisation of foreign banks and access to liquidity from the parent office, credit supplied to the economy by banks with international owners may be more stable. Chart SF2.2 shows how increasing foreign

26 The lower share of foreign-owned banks in Romania as of 2004 will increase to around $75-80 \%$ in early 2006 due to finished privatisation of the biggest Romanian bank Banca Comerciala Romana to the Austrian Erste Bank.

27 A detailed analysis of five biggest banks in the acceding and candidate countries reveals additional interesting features: in Bulgaria and Croatia, the five biggest banks, accounting for around $50 \%$ and $80 \%$, respectively, are all foreign-owned. In both countries, only one of the top-five banks got the share only via greenfield investment, while the other via privatisation. In Romania, with the privatisation of the biggest bank in early 2006 , all of the top five banks (around $60 \%$ of the market) will be foreign-owned, with one of them having obtained the share via greenfield investment. In Turkey, the biggest bank and the fifth biggest bank are still state-owned, while the three other banks of the top five (around $60 \%$ of the market) are domesticowned, private banks.

28 Among others, see for example Clarke, George et al. (2001): Foreign bank entry. WB Policy Research Working Paper; Weill, Laurent (2003): Banking efficiency in transition economies. Economics of Transition 11 (3); Haas and Lelyveld (2002): Foreign bank penetration and private sector credit in Central and Eastern Europe. DNB Staff Report 91. 


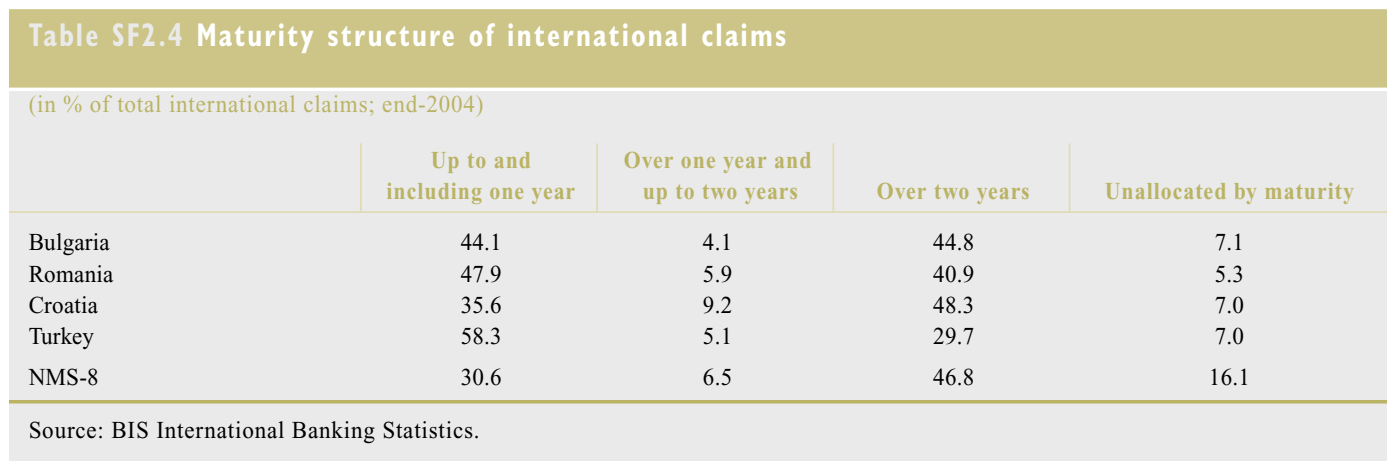

ownership can lead to a decrease in the share of bad loans in banks' portfolios.

There may, however, be also risks stemming from foreign bank penetration for financial stability. For example, foreign owners may push local managers into riskier business ventures with the promise of ambitious returns, especially if profit from local subsidiaries in the host countries is used to finance less profitable businesses in the home country. The repatriation of local banks' profit may then also put pressure on the current account. Foreign-owned banks may prefer to provide local loans in foreign currency, especially in the currency of the home country if they refinance themselves in the home market via the parent bank. This could make borrowers more vulnerable to exchange rate movements and increase credit risk for banks. Other risks may occur if decision-making and risk management activities are transferred to the foreign headquarters or if rules are standardised across the whole banking group without taking account of local interests, thus making it more difficult for local small and medium-sized enterprises to access finance. ${ }^{29}$

Two financial stability potential issues deserve further analysis: sudden capital withdrawals and contagion. These two issues have been analysed using data on international bank lending. However, due to data limitations and rapid developments within the banking sector, this analysis can only be seen as a snapshot. To analyse the potential for sudden capital withdrawals, we look at the maturity structure of cross-border claims.
Table SF2.4 shows the maturity breakdown of international claims on the acceding and candidate countries and the NMS-8. ${ }^{30}$ In Turkey, a considerable part of international claims are short-term claims with a maturity of up to two years; in the other acceding and candidate countries, the share of short-term claims is higher than in the NMS-8. However, international claims unallocated by maturity, i.e. mainly shares and other participations, are lower in the acceding and candidate countries than in the NMS-8. In so far as holdings of shares represent portfolio investments, the risk of a sudden outflow might be comparable across countries with the exception of Turkey.

To analyse the potential for contagion, we look at the participation of a large international banks in several acceding and candidate countries or new Member States. Host countries with a common creditor may be sensitive to shocks hitting the home country of the bank. ${ }^{31}$ Furthermore, if a shock occurs in a host country where an international bank has its stakes, the bank may be forced to reduce its lending or sell

29 For a discussion of the link between foreign bank presence and access to credit of small and medium-sized firms see Clarke et al. (2001): Does foreign bank penetration reduce access to credit in developing countries? WB Policy Research Working Paper 2716

30 Unfortunately, maturity breakdown of total foreign claims is not available.

31 See, for example, the seminal works by Kaminsky and Reinhart (2000): On crisis, contagion and confusion. Journal of International Economics 51; and Peek and Rosengren (2000): Collateral Damage: Effects of the Japanese Bank Crisis on Real Activity in the United States. American Economic Review 90 (1), or Sbracia and Zaghini (2001): The Role of the Banking System in the International Transmission of Shocks. Banca D'Italia Discussion Paper No. 409. 


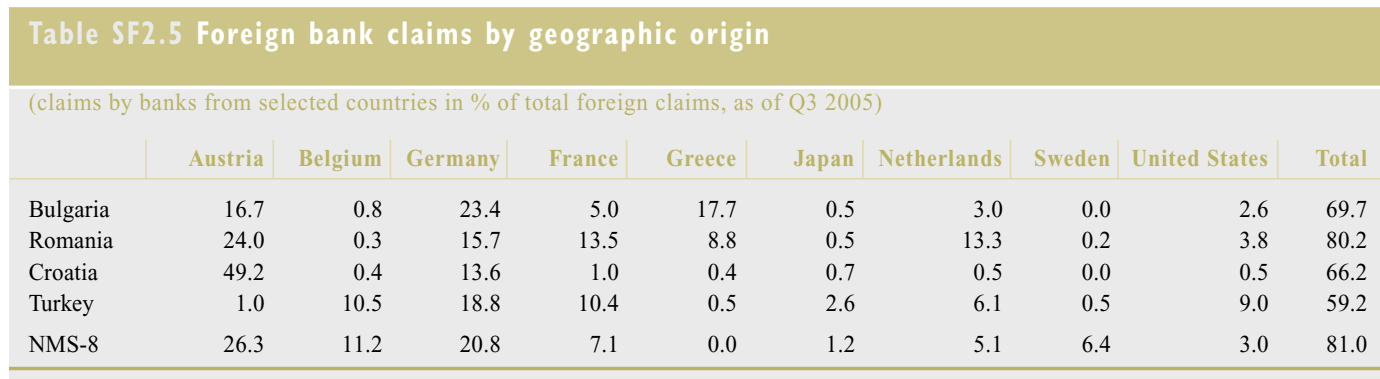

Source: BIS International Banking Statistics.

assets in another host country in order to restore balance sheet health. The risk of transmitting shocks from the home country to a host country depends on many factors, including the form of the foreign presence (subsidiary, branch or cross-border credit) and the degree of diversification of the foreign owners. Table SF2.5 shows the breakdown of foreign claims by geographic origin of the creditor and reveals that foreign claims on the acceding and candidate countries and on the NMS- 8 are rather concentrated, coming from only a few, mainly EU countries. ${ }^{32}$ In Croatia, foreign claims from Austria account for almost $50 \%$ of all foreign claims, which suggests that the Croatian banking sector may be relatively sensitive to economic conditions in Austria.

There is some evidence of potential contagion from one host country to another via common creditor effect because the acceding and candidate countries share some of the same creditors. To capture the "similarity" of the structure of claims by geographic origin, we calculate common creditor indices. ${ }^{33}$ The index measures the similarity in patterns of creditors between any two countries and is bounded between 0 and 1 ( 1 indicates the same composition of creditors, while 0 indicates no common creditor). Table SF2.6 presents the results for the four acceding and candidate countries.

As the table shows, the four countries indeed share some common creditors with each other and with the NMS-8. This reflects the expansion strategies of several (mainly EU-based) banking groups which have acquired significant shares in domestic banking sectors in a number of Central and Eastern European countries. However, other conditions would have to be fulfilled (the common creditor bank would have to be rather weak and the adverse shock rather large) before the common creditor effect materialised and posed a risk to financial stability. Nevertheless, a strong foreign presence in the banking sectors of Bulgaria, Romania

32 Unfortunately, the BIS data did not include claims by Italian banks, which are very active in the region.

33 The common creditor index is computed using the methodology of Van Rijckeghem and Weder (2001): Sources of Contagion: Finance or Trade? Journal of International Economics 54 (2).

\begin{tabular}{|c|c|c|c|c|c|c|c|c|c|c|c|c|}
\hline \multicolumn{13}{|c|}{ (as of Q3 2005) } \\
\hline & Bulgaria & Romania & Croatia & Turkey & $\begin{array}{r}\text { Czech } \\
\text { Rep. }\end{array}$ & Estonia & Hungary & Latvia & Lithuania & Poland & Slovakia & Slovenia \\
\hline Bulgaria & 1.00 & 0.71 & 0.55 & 0.57 & 0.46 & 0.11 & 0.74 & 0.32 & 0.31 & 0.63 & 0.54 & 0.61 \\
\hline Romania & 0.71 & 1.00 & 0.55 & 0.56 & 0.59 & 0.14 & 0.65 & 0.25 & 0.24 & 0.57 & 0.55 & 0.61 \\
\hline Croatia & 0.55 & 0.55 & 1.00 & 0.53 & 0.53 & 0.15 & 0.61 & 0.23 & 0.20 & 0.51 & 0.81 & 0.70 \\
\hline Turkey & 0.57 & 0.56 & 0.53 & 1.00 & 0.43 & 0.16 & 0.61 & 0.26 & 0.25 & 0.73 & 0.48 & 0.53 \\
\hline
\end{tabular}

Sources: BIS International Banking Statistics and author's calculations. 
and Croatia may present a challenge from the financial stability perspective and calls for further detailed analyses of potential contagion effects.

\section{SPECIAL FEATURE 3: THE ROLE OF FOREIGN CURRENCIES}

Extensive foreign currency transactions can have implications for financial stability as they can give rise to significant currency mismatches, whereby the income or net worth of an economic entity is exposed to changes in the exchange rate. This can imply major vulnerability in the event of a financial crisis. Experience has shown that, while currency mismatches tend not to precipitate financial crises, they can play a major role in exacerbating them and making them very costly to resolve, with taxpayers often bearing most of the clean-up costs. A financial crisis usually precipitates sharp currency depreciation, which inflates the value of debt and interest payments denominated in foreign currency, in so far as borrowers are not hedged against adverse exchange rate fluctuations (either through natural or financial hedging), which is often the case for households and smaller enterprises. This can, at a stroke, make economic entities insolvent and deteriorate banks' asset quality, which can lead to further economic disruption and currency depreciation. A vicious cycle of this kind was a key factor behind the severity of the Asian financial crisis of 1997-98.

Banks transfer currency risk to their customers by lending in foreign currency and financing this abroad. In such a situation, which has become increasingly characteristic for acceding and candidate countries in recent years, currency mismatching tends not to be significant on bank balance sheets, particularly as banks are relatively adept at hedging residual balances. However, given that this leads to currency mismatches among households and non-bank corporations (on top of increased direct borrowing from abroad, either from financial intermediaries, parent companies or via trade credit), this translates into credit risks for banks. In practice, the data are rarely available beyond aggregates at the sectoral level, and this is also the case for the four countries examined in this report. For households, which usually do not have substantial foreign currency income, currency mismatch problems on the individual level are likely to be significant, even if there may be no significant currency mismatch on the aggregate level. For non-bank corporations, at least in the tradable sector, there may be a smaller probability of a currency mismatch if total loans and deposits in foreign currency are close in the aggregate since export revenues may hedge the residual exchange rate risk. At the same time, anecdotal evidence suggests that significant foreign currency borrowing in nonexporting sectors may be an issue in some of the four countries under review.

Foreign currencies play a significant role in the banking sectors of the acceding and candidate countries. This role originates to some extent from a lack of confidence in the domestic currency (and the domestic banking sector) on the part of households at the beginning of the transformation process. Later on, when foreign currency holdings were moved from under mattresses to domestic bank accounts, households preferred foreign currency deposits. Even following successful economic and financial stabilisation over the past few years, the high share of deposits denominated in foreign currency has been fairly persistent, while borrowing in foreign currencies has become attractive due to lower interest rates, in the apparent expectation that the interest rate differential would not be compensated by depreciation of the domestic currency. Moreover, for some borrowers, foreign currency debt payments may smooth earnings fluctuations arising from export revenues in foreign currency. On the lending side, the large share of foreign currencies can be seen as a natural hedge of banks' foreign currency liabilities (from taking foreign currency deposits and loans abroad, or from the payment of equity capital by foreign owners). Furthermore, growth opportunities are seen as considerable in the banking sectors of 


\section{Table SF3.I Foreign currency deposits, 2005}

\section{(shares in $\%$ of the total deposits from the respective sectors)}

Share of foreign currency deposits of households and non-bank corporations ${ }^{1)}$

of which:

share of foreign currency deposits of households ${ }^{2}$

share of foreign currency deposits of non-bank corporation.

\begin{tabular}{rrrr} 
Bulgaria & Croatia & Romania & Turkey \\
& & & \\
46.8 & 71.0 & 34.5 & 41.3 \\
& & & \\
54.2 & 80.6 & 37.0 & 42.0 \\
35.0 & 44.2 & 53.9 & 38.9 \\
\hline
\end{tabular}

Source: national central banks.

1) Croatia: Before 2004 including deposits by non-residents and deposits by the general government.

2) Croatia: Before 2004 without non-profit institutions.

these countries, especially as credit is taking off from a low base, encouraging banks to expand credit beyond what can be funded by the domestic deposit base. Foreign ownership of domestic banking sectors also facilitates funding from abroad.

Tables SF3.1 and SF3.2 report data on the shares of foreign currency deposits and loans in all four countries at the end of 2005. It is worth noting that these figures may underestimate the full significance of foreign currencydenominated deposits and loans, as they exclude deposits and loans indexed to foreign currencies. Indexed instruments are particularly important in Croatia, where they accounted for $12.8 \%$ of total deposits and $66.6 \%$ of total loans of households and non-bank corporations at the end of 2005, while there are indications that foreign-currency indexation of loans is also significant in Turkey.
In the run-up to the euro cash changeover of January 2002, the share of foreign currencydenominated deposits was boosted in Bulgaria, Romania and Turkey, as residents deposited holdings of euro legacy currencies for conversion. In Croatia, the volume of both total and foreign currency-denominated deposits increased but the share of foreign currencydenominated deposits did not rise further, as it had already accounted for $87 \%$ and some of the foreign currency holdings were converted into domestic currency. After the introduction of the euro banknotes and coins, the share of foreign currency deposits began to erode in all four countries and this has continued since, reaching levels below those observed prior to the boost in all of the countries except Turkey. In Croatia, however, most of the decline in the share of foreign currency-denominated deposits was replaced by an increase in the share of foreign currency-indexed deposits.

\begin{tabular}{|c|c|c|c|c|}
\hline \multicolumn{5}{|l|}{ (shares in $\%$ of the total loans to the respective sectors) } \\
\hline & Bulgaria & Croatia & Romania $^{1)}$ & Turkey \\
\hline $\begin{array}{l}\text { Share of foreign currency loans to households and non-bank corporations }{ }^{2} \text { ) } \\
\text { of which: }\end{array}$ & 47,3 & 10,2 & 54,0 & 15,9 \\
\hline share of foreign currency loans to households & 15,4 & 0,5 & 44,1 & n.a. \\
\hline share of foreign currency loans to non-bank corporations & 66,9 & 21,7 & 59,4 & n.a. \\
\hline
\end{tabular}


On the lending side, the share of foreign currency loans increased significantly in 2002 in all four acceding and candidate countries, as a result of additional foreign currency funding from domestic deposits or bank borrowing abroad. Thereafter, the share of foreign currency loans in total loans continued to increase strongly in Bulgaria, reflecting the ongoing domestic lending boom, while it fell markedly in Turkey, where decreasing interest rate differentials vis-à-vis the euro and the US dollar appear to have played a determining role. After increasing up to 2004, there has also been a decline in the share of foreign currency loans in Romania in 2005 apparently reflecting specific measures introduced by the National Bank of Romania to discourage such lending. Increased exchange rate flexibility may also have acted as a disincentive more recently, by making borrowers more aware of the risks. The share of foreign currency loans declined modestly in Croatia though this is likely to reflect substitution in favour of domestic currency loans indexed to foreign currencies. In countries with sizeable exchange rate volatility, such as Turkey and Romania, developments in the share of foreign currencies have also been significantly influenced by the statistical effect of exchange rate changes. Furthermore, the structure of domestic lending has been affected more generally by the bank consolidation process (e.g. by writing off loans).

Significant foreign currency lending to domestic households and enterprises raises the question of the size of commercial banks' open foreign currency position on the balance sheet and their coverage by off-balance-sheet positions. According to published data, banks' net overall foreign currency positions are small in all four acceding and candidate countries. In the middle of 2005 , Croatian banks had a small positive (long open) position of around $0.2 \%$ of their (on-balance-sheet) assets. At the same time, Bulgarian banks had a small negative (short open) position of $0.4 \%$ (excluding exposure to the euro, in line with central bank regulations). Romanian and Turkish banks had nearly balanced positions by the end of $2005(+0.1 \%$ and $-0.1 \%$ of total assets, respectively). These net overall positions are in line with or even smaller than those observed for most NMS.

At the same time, banks face substantial indirect foreign exchange risks as a result of foreign currency-related positions on the asset side, through a possible deterioration in their (unhedged) borrowers' debt servicing capacity following a depreciation of the domestic currency. This situation may be accentuated by the fact that the non-bank corporate sector's foreign indebtedness has increased significantly over the past few years in Bulgaria, Croatia and Romania, thereby increasing the exposure to exchange rate risk.

Some trends have tended to mitigate risks from large foreign currency exposure in the acceding and candidate countries. First, the currency structure of domestic foreign currency loans to households and corporations has improved over the past few years, at least in so far as evidence is available. At the end of 2004 foreign currency loans denominated in euro accounted for nearly $90 \%$ of total foreign currency loans to households and corporations in Bulgaria and for $70 \%$ in Romania. Anecdotal evidence suggests that the euro also accounts for a high share of foreign currency lending in Croatia (although lending in other foreign currencies, notably Swiss francs, seems to be gaining momentum). A currency breakdown of foreign currency loans is not available for Turkey. Second, foreign exchange reserves are accumulating steadily (particularly in Romania, Bulgaria and Turkey), increasing the ability of central banks to stem exchange rate depreciation pressures at times of tension. Finally, domestic bond markets are developing well in the candidate countries, with turnover and maturities increasing, which should eventually provide more domestic alternatives for debt. However, developing a corporate bond market should only be seen as a long-term process, and, furthermore, a domestic bond market would do little to reduce exchange rate risks among households. 
Monetary and exchange rate policies can play a role in containing foreign exchange lending. Ideally, the monetary framework should not provide unintended incentives for the use of foreign currencies in banks' transactions. However, the scope of monetary policy is often limited by exchange rate commitments or considerations. Mandatory reserve regulations, which are at the disposal of policy-makers under any exchange rate regime, may offer some room for affecting the currency composition of bank liabilities, and some of the acceding and candidate countries have made use of this instrument. Under flexible exchange rate regimes, higher exchange rate volatility can make borrowers more aware of the exchange rate risks connected to foreign currency borrowing. In this respect, it is notable that Romania has introduced more flexibility into its exchange rate since late 2004.

Apart from monetary and exchange rate policy, moral suasion and prudential measures can also help keep foreign currency lending under control. Prudential measures are particularly appropriate if and when foreign currency lending implies financial stability risks. These measures can be targeted either at creditors (e.g. limits on banks' foreign liabilities, prescribed ratios between foreign currency assets and liabilities or between foreign currency lending and bank capital, differentiated classification and provisioning rules, collateral requirements, capital requirements and risk weights for foreign currency loans), or at borrowers (prescribed maximum ratio between foreign currency debt servicing and the borrower's income). Authorities in the acceding and candidate countries have already applied several such measures, but there still appears to be scope for further utilisation of some of these instruments. It should be noted, however, that prudential measures may lose some of their effectiveness over time as customers bypass regulations, for example by obtaining foreign currency loans from leasing companies, or directly borrow from abroad. Finally, fiscal restraint - if leading to an increase in the domestic savings ratio - would serve to curtail credit growth in general, including the foreign currency element.

\section{SPECIAL FEATURE 4: THE SUPERVISORY FRAMEWORK \\ I STRUCTURE OF THE REGULATORY AND SUPERVISORY FRAMEWORKS}

Banking regulatory and supervisory frameworks have been substantially reformed in the acceding and candidate countries. As a consequence of the banking crises of the late 1990s and early 2000 s, all of the acceding and candidate countries have improved their supervisory and regulatory frameworks for banking activities. In all four countries, banking supervision is now exercised by autonomous institutions: in Bulgaria, Romania and Croatia by the respective central banks; and in Turkey by the BRSA.

Progress was reported in the IMF's Financial Sector Assessments conducted for Bulgaria, Romania and Croatia. According to the reports, the banking supervisory framework was deemed to be fully compliant or largely compliant with almost all of the Basel Core Principles for Effective Banking Supervision in Bulgaria, compliant or largely compliant in Romania, and largely compliant in Croatia. The FSAP update conducted for Bulgaria in 2004 noted that the banking sector continued to operate in an environment of sound supervision and welcomed the implementation of several FSAP recommendations, including the creation of a financial sector supervisory committee, a Council for Financial Stability and a more effective bank insolvency regime. Many FSAP recommendations have also been implemented in Romania, including the introduction of consolidated supervision, improved information exchanges with foreign banking supervisors and a clarification of the rules on acquisitions and investment in the banking sector.

In Turkey, a new banking law was passed in 2005. The 2001 banking crisis - as well as the Imar bank failure in July 2003 - exposed a 
number of serious shortcomings in Turkey's institutional framework. The new banking law, which was adopted in October 2005, provides for increased transparency and disclosure requirements for banks. It also (i) clarifies the division of responsibilities between the BRSA and the other entities dealing with supervision (i.e. the Savings Deposits Insurance Fund (SDIF), the Sworn Bank auditors and the Treasury); (ii) establishes a liquidity ratio; and (iii) widens the range of business operations that require a banking license. The new law brings the legal framework more into line with EU standards and international best practices. However, the provisions related to the supervision of financial conglomerates and consumer protection are not compliant with EU rules.

The regulatory and supervisory frameworks are also being transformed to comply with the “acquis communautaire”. In its autumn 2005 reports, the European Commission concluded that the transposition of legislation in the banking sector was almost complete in Romania and that good progress had been made in Bulgaria. In Croatia, the legislation was found to be only partially aligned with the body of EU law, while in Turkey the level of alignment was deemed to be moderate regarding the banking area but limited in terms of aligning the regulatory framework of non-bank financial institutions.

As the regulatory framework has been improved, supervisory capacity has also been increased. In its autumn 2005 monitoring reports the Commission noted how the capacity and expertise of the supervision had been constantly upgraded in Bulgaria, while the administrative structures in place in Romania were deemed to function adequately. Improvements in the capacity of Banca Națională a României to assess overall financial system stability had been noted by a recent IMF mission. Progress has also been made in Croatia, where since 2004 the Croatian National Bank has been able to conduct on-site supervision and its Banking Supervisory Department has been reorganised.
The Central Bank of the Republic of Turkey issued its first financial stability report in the summer of 2005, whereas Banca Națională a României's published its first such report in spring 2006.

Further improvements to the supervisory frameworks are still necessary in a number of areas. In Bulgaria, progress needs to be completed as regards the single passport principle, the differentiation between foreign and EU credit institutions and the definition of branches. In Romania, the members of the peer advisory mission on financial services supervision, which took place in July 2005 under the auspices of the European Commission, concluded that more attention should be paid to the issue of financial conglomerates and to the preparation of International Accounting Standards.

Cooperation with foreign supervisors can also be further improved. For Romania, the IMF recommended that Banca Națională a României be required to consult with the home supervisor before licensing foreign subsidiaries or authorising foreigners to acquire Romanian banks. The amendment to the banking law was limited to a consultation with EU countries. In Croatia, cooperation with foreign supervisors, which received a legal underpinning in 2002, needs to be implemented more effectively.

Supervision of non-bank financial activities is less developed than banking supervision. Following the FSAP recommendations, Bulgaria introduced a single supervisory agency for nonbank financial institutions. The FSAP update noted, however, that Bulgaria's supervisory capacity, regulatory framework and enforcement powers still needed to be further strengthened. Romania has recently extended supervision to cover non-bank credit institutions in an attempt to control the growth of leasing and other nonbanking activities. In 2004 Croatia merged the supervisory authorities for the insurance sector, the pension funds and the securities markets. However, the European Commission's latest monitoring report found that Croatia's new 
Financial Services Authority still lacked the necessary legal basis to become the single supervisory authority for the non-bank financial system. In Turkey, the fragmented nature of supervision and regulation is a significant problem: while banks are regulated by the BRSA, leasing, factoring and consumer finance companies and the insurance sector are regulated and supervised by four different General Directorates of the Under-Secretariat of the Treasury.

\section{MINIMUM CAPITAL REQUIREMENTS}

Progress has been made with regard to minimum capital requirements. At the time of the FSSA missions, the minimum capital adequacy ratios were found to be not fully consistent with the Basel I Capital Accord in Bulgaria, Romania and Croatia. The IMF noted that the calculation of the ratio was based on credit risk alone, and recommended that the ratio be calculated by including market and market-related risks and on a consolidated basis. These recommendations were implemented in Croatia and Romania in 2004 and in Bulgaria in 2005.

The shift to the Basel II framework will require further changes. By the time of accession, the new capital requirement framework (known as "Basel II") needs to be incorporated in the respective national legislation of Bulgaria and Romania. In Romania, a "Basel II project" has been launched to achieve this goal. The main objectives of this project refer to the alignment of the national legislative framework to the new provisions and to the preparation of the supervisory authority and of the credit institutions for implementing the new prudential requirements. In Turkey the BRSA has adopted a detailed road map for implementing the Basel II framework of capital requirements from January 2008, with the less advanced approaches, and from January 2009 for the advanced ones. Training efforts to develop the administrative capacity of moving towards riskbased supervision should continue.

\section{DEPOSIT INSURANCE}

An explicit and compulsory deposit insurance system is in place in the four countries under review. Schemes are funded by banks in Bulgaria, Romania and Croatia, and jointly by the government and banks in Turkey. The guarantee covers domestic currency as well as foreign exchange account holders in the four countries. With regard to the specifics of these deposit insurance schemes, it is worth noting that Romanian scheme covers individuals as well as small and medium-sized companies. In Bulgaria, foreign branches covered by the schemes applicable to their head offices are not obliged to participate in the domestic scheme. The body of EU law requires in this case that at least an equivalent level of protection be offered.

Only in Turkey is the guarantee per depositor in accordance with the level prescribed by EU rules. In Bulgaria and Romania, the guarantee has already been gradually raised and will reach the equivalent of $€ 20,000$ by the time they join the EU, foreseen on 1 January 2007, in order to be in line with the body of EU law. There is no limit per account in any of these countries, with the exception of Bulgaria, where it is set at the same level as the limit per depositor. Moreover, formal co-insurance only exists in Croatia (i.e. depositors are only insured for a percentage of

\begin{tabular}{|c|c|c|c|c|}
\hline \multicolumn{5}{|l|}{ (in \%) } \\
\hline International standards (Basel) & Bulgaria & Croatia & Romania & Turkey \\
\hline 8 & 12 & 10 & 12 & 8 \\
\hline
\end{tabular}




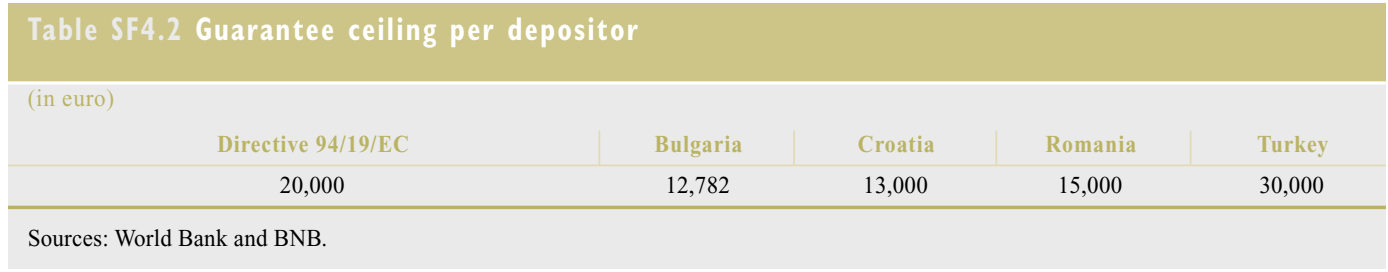

their deposits even if the deposit is worth less than the established limit).

Deposit guarantee schemes need, however, to be strengthened. In Romania, the FSAP mission concluded that the resources of the deposit guarantee fund needed to be considerably strengthened. In Croatia, the division of responsibilities and coordination between the Croatian National Bank and the State Agency for Deposit Insurance and Bank Rehabilitation could be clarified and improved to avoid conflict of interests and ensure a "least-cost resolution" mechanism. In Turkey, the IMF has voiced its concern that the balance sheet of the SDIF was extremely weak as most of its resources are made up of a loan from the Treasury, which thus bears the final financial burden in case of failures.

\section{LOAN CLASSIFICATION}

Loan classification and provisioning requirements have been progressively strengthened in the four countries. The primary system of loan classification in Bulgaria and Croatia is based on both the number of days of arrears and a forward-looking estimate of the probability of default, whereas in Romania and Turkey it is based only on the number of days in arrears. In Romania, the regulations provide for three classification criteria: debt service (number of days of arrears), financial performance of the borrower and initiation of judicial proceedings. In all countries, specific minimum provisioning ratios are required for each category of loans.

\section{MEASURES TO COMBAT MONEY LAUNDERING}

Acceding countries are also required to meet the EU's anti-money laundering legislation. EU directives and regulations to combat money laundering and the financing of terrorism, especially the Third Directive that entered into force on 15 December 2005, incorporate the $40+9$ revised Recommendations of the FATF into Community law. The legislation establishes money laundering as a criminal offence and requires financial institutions to identify and know their customers, to keep appropriate records and to report any suspicious transactions. These provisions also apply to auditors' activities, external accountants, notaries and lawyers, casinos and real estate agents. Moreover, they require adequate enforcement capacity and include specific provisions related to the financing of terrorism and to money laundering.

Further progress in complying with the "acquis" is required by Bulgaria and Romania. According to the European Commission's 2005 monitoring reports on Bulgaria and Romania, national legislations were in line with the Second AntiMoney Laundering Directive but should be aligned with the Financial Action Task Force's revised recommendations and with the Third EU Directive. Moreover, in Romania, the members of the above-mentioned peer advisory mission in July 2005 found that there were still loopholes in the legislation. In particular, money transmitters are not subject to any form of supervision.

In Croatia and Turkey, both legislation and enforcement need to be considerably strengthened. In its assessments of anti-money 


\begin{tabular}{|c|c|c|c|c|}
\hline & Bulgaria & Croatia & Romania & Turkey \\
\hline \multicolumn{5}{|c|}{ Number of days after which a loan in arrears is classified as: } \\
\hline Standard & $0-30$ & $\begin{array}{c}0-60 \\
\text { (category A: fully } \\
\text { recoverable placements) }\end{array}$ & $\begin{array}{l}0-15 \text { for category A } \\
\text { (classification of the } \\
\text { financial performance of } \\
\text { the borrower) }\end{array}$ & $0-89$ \\
\hline Watch & $31-60$ & \multirow{3}{*}{$\begin{array}{l}\text { 61-180 (category B: } \\
\text { partly recoverable } \\
\text { placements) }\end{array}$} & $\begin{array}{l}\text { From } 0-15 \text { for category } \\
\mathrm{B} \text {, from } 16-30 \text { days for } \\
\text { category A }\end{array}$ & \\
\hline Sub-standard & $61-90^{1)}$ & & $\begin{array}{c}\text { From } 0-15 \text { days for } \\
\text { category } C, 16-30 \text { days for } \\
\text { category B, 31-60 days for } \\
\text { category A }\end{array}$ & $90-179$ \\
\hline Doubtful & & & $\begin{array}{c}\text { From 0-15 days for } \\
\text { category D, } 16-30 \text { days for } \\
\text { category C, } 31-60 \text { days for } \\
\text { category B and } 61-90 \text { days } \\
\text { for category A }\end{array}$ & 180 \\
\hline Loss & $(\text { NPL category })^{3)}$ & $\begin{array}{c}181 \\
\text { (category C : } \\
\text { irrecoverable placements) }\end{array}$ & $\begin{array}{c}\text { Debt service minimum } \\
91 \text { days and financial } \\
\text { performance category A, B, } \\
\text { C, D and E; } ; \text {, }\end{array}$ & Over 1 year \\
\hline \multicolumn{5}{|c|}{ Minimum provisioning required as loans become: } \\
\hline Standard & $0 \%$ & $\begin{array}{c}\text { From } 0.85 \% \text { to } 1.20 \% \\
\text { for category } \mathrm{A}\end{array}$ & $0 \%$ & $5 \%$ \\
\hline Watch & $\begin{array}{l}10 \% \text { for corporate } \\
\text { loans / } \\
20 \% \text { for individual } \\
\text { loans }\end{array}$ & $\mathrm{na}^{4)}$ & $5 \%$ & $5 \%$ \\
\hline Substandard & $\begin{array}{l}50 \% \text { for corporate } \\
\text { loans / } 75 \% \text { for } \\
\text { individual loans }\end{array}$ & $\mathrm{na}^{4)}$ & $20 \%$ & $20 \%$ \\
\hline Doubtful & & $n a^{4)}$ & $50 \%$ & $50 \%$ \\
\hline Loss & $\begin{array}{l}100 \% \text { for every } \\
\text { type of loans } 3 \text { ) }\end{array}$ & $\mathrm{na}^{4)}$ & $100 \%$ & $100 \%$ \\
\hline
\end{tabular}

Sources: World Bank and BNR

1) Or the debtor's financial state has deteriorated.

2) Or the debtor suffers a permanent shortage of funds, is in bankruptcy or liquidation, or the claim is subject to court proceedings.

3) The doubtful and loss exposures were amalgamated into the non-performing loan category as of 1 April 2004.

4) Not applicable.

5) Or debt service 61-90 days and financial performance category B, C, D and E or debt service 31-60 days and financial performance category $\mathrm{C}, \mathrm{D}$ and $\mathrm{E}$ or debt service 16-30 days and financial performance category D and $\mathrm{E}$ or debt service 0-15 days and financial performance category E, as well as any credit for which judicial procedures have been initiated, regardless of debt service or financial peformance category. 
laundering legislation and practices, the European Commission concluded that the scope of transactions, activities requiring client identification and reporting had to be broadened, especially with regard to professions such as lawyers, external accountants and tax advisors, as well as government transactions. The obligation of due diligence in non-face-to-face transactions has to be introduced. Moreover, in Turkey, there is no provision on terrorist financing.

In the four countries under review, increased efforts are needed with regard to the implementation of legislation. The Commission has asked the authorities to further strengthen administrative and enforcement capacities, to reinforce controls on reporting entities and to ensure more effective cooperation between relevant authorities, especially the Financial Intelligence Unit (FIU) and the Prosecution Office. In all four countries, it emphasises that the effectiveness of the anti-money laundering framework is seriously hampered by corruption, organised crime and the large informal economy. Moreover, the track record on enforcement remains weak, as the number of indictments has been low up to now (see Table SF4.4). In Romania, further secondary legislation and professional regulations have to be elaborated: although exchange bureaux are licensed by Banca Națională a României, they are not effectively supervised. Therefore, the Commission considered that enforcement needed substantial improvement. In both Croatia and Turkey, cooperation between the FIU and foreign counterparts remains limited. In both countries, awareness of the members of the banking community and other reporting entities with regard to the money laundering offence needs to be enhanced. Furthermore, in Turkey, the availability of statistical information needs to be enhanced. The attribution of tasks to these various entities has to be clarified. There is a lack of provisions protecting institutions and their employees from liability when reporting suspicious transactions. Finally, it should be noted that Turkey's implementation of the framework for combating money laundering and the financing of terrorism will be reviewed by the FATF for the third time in early 2006 .

\begin{tabular}{|c|c|c|c|c|}
\hline \multicolumn{5}{|c|}{ (2004 Figures, unless otherwise stated) } \\
\hline & Bulgaria & Croatia & Romania & Turkey (2005) \\
\hline $\begin{array}{l}\text { Number of reported suspicious } \\
\text { transactions }\end{array}$ & 432 & $n a^{1)}$ & 2,054 & 352 \\
\hline Number of cases prosecuted & 21 & $30-40$ each year & $\begin{array}{l}304 \text { cases } \\
\text { submitted to the } \\
\text { General Prosecutor } \\
\text { in the first six } \\
\text { months of } 2005\end{array}$ & 33 \\
\hline Indictments & 7 & $\mathrm{na}^{1)}$ & $\begin{array}{c}3 \\
(2001-04)\end{array}$ & 15 \\
\hline Convictions & $\mathrm{na}^{1)}$ & $\begin{array}{c}2 \\
(2001-2004)\end{array}$ & $\mathrm{na}^{1)}$ & $\mathrm{na}^{1)}$ \\
\hline
\end{tabular}





\section{Bulgaria: Selected macroeconomic indicators}

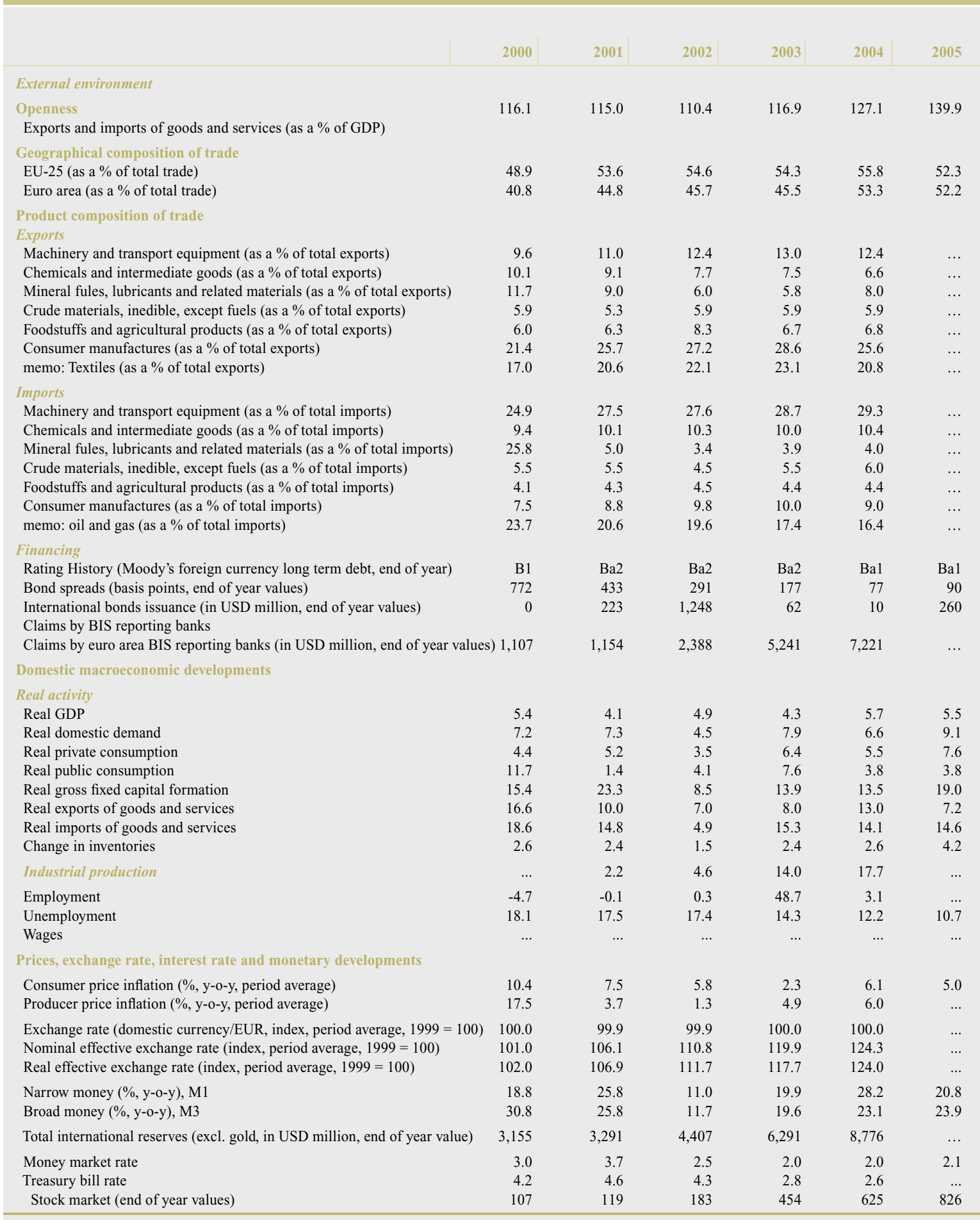

1) The country sheets have been compiled for comparison purposes between countries. Thus, some of the data may differ slightly from the tables provided in the main text, which mainly rely on national sources. 


\begin{tabular}{|c|c|c|c|c|c|c|}
\hline & 2000 & 2001 & 2002 & 2003 & 2004 & 2005 \\
\hline \multicolumn{7}{|l|}{ Government sector } \\
\hline Central government balance & $\ldots$ & $\ldots$ & $\ldots$ & $\ldots$ & $\ldots$ & $\ldots$ \\
\hline Central government expenditure and net lending & $\ldots$ & $\ldots$ & $\ldots$ & $\ldots$ & $\ldots$ & $\ldots$ \\
\hline General government primary balance & 3.4 & 3.1 & 1.6 & 2.1 & 3.6 & 4.0 \\
\hline General government balance & -0.6 & -0.6 & -0.6 & 0.0 & 1.7 & 2.4 \\
\hline General government expenditure and net lending & 39.7 & 38.4 & 37.1 & 38.2 & 37.3 & 36.9 \\
\hline General government gross debt & 77.1 & 69.9 & 56.2 & 48.2 & 40.9 & 32.4 \\
\hline General government net debt & 66.0 & 63.5 & 58.5 & 51.3 & 40.1 & 36.9 \\
\hline \multicolumn{7}{|l|}{ External sector } \\
\hline Current account balance & -5.6 & -5.6 & -2.4 & -5.5 & -5.8 & -11.8 \\
\hline Trade balance & -9.4 & -11.7 & -11.4 & -13.7 & -15.1 & -20.4 \\
\hline Services balance & 4.0 & 2.2 & 3.1 & 3.1 & 3.5 & 3.1 \\
\hline Net factor income & -3.2 & -2.2 & -1.7 & -3.0 & 0.0 & 0.0 \\
\hline Net current transfers & 2.3 & 3.7 & 3.5 & 3.4 & 4.6 & 4.4 \\
\hline Capital account balance & 0.2 & 0.0 & 0.0 & 0.0 & 0.0 & 0.0 \\
\hline Financial account balance & 6.6 & 5.0 & 11.1 & 13.2 & 14.9 & 13.4 \\
\hline Net foreign direct investment & 8.0 & 5.9 & 5.8 & 10.3 & 11.5 & 8.7 \\
\hline Net portfolio investment & -1.4 & 0.6 & -0.6 & -1.1 & -2.9 & -3.5 \\
\hline Net other investment & -0.1 & -1.5 & 6.0 & 3.9 & 6.3 & 8.3 \\
\hline Change in reserve assets & 3.6 & 2.1 & 3.5 & 4.6 & 7.6 & 1.5 \\
\hline \multicolumn{7}{|l|}{ Convertible currency external debt } \\
\hline as $\%$ of GDP & 86.9 & 78.6 & 65.1 & 60.3 & 63.0 & 67.5 \\
\hline$y$-o-y rate of change & 9.6 & 0.4 & -9.8 & -1.2 & 15.1 & 17.0 \\
\hline Total debt service (\% of exports of goods and services and income) & 15.9 & 19.7 & 15.8 & 13.7 & 22.4 & 41.8 \\
\hline \multicolumn{7}{|l|}{ By debtor: } \\
\hline \multicolumn{7}{|l|}{ Public sector* } \\
\hline$y-0-y$ rate of change & $\begin{array}{r}5.5 \\
5.5\end{array}$ & -1.5 & -19.0 & $\begin{array}{r}51.3 \\
-11.3\end{array}$ & $\begin{array}{c}50.0 \\
-12.1\end{array}$ & -24.5 \\
\hline \multicolumn{7}{|l|}{ Private sector* (including DMB) } \\
\hline as $\%$ of GDP & 18.5 & 17.9 & 19.9 & 22.8 & 33.0 & 46.8 \\
\hline$y-0-y$ rate of change & 27.5 & 7.7 & 21.5 & 21.6 & 59.9 & 54.6 \\
\hline \multicolumn{7}{|l|}{ Deposit money banks } \\
\hline$y-0-y$ rate of change & 11.8 & -13.1 & 42.2 & 90.0 & 116.7 & 47.3 \\
\hline \multicolumn{7}{|l|}{ Short-term debt } \\
\hline as $\%$ of reserves excluding gold & 43.4 & 35.9 & 41.5 & 45.5 & 38.5 & 53.9 \\
\hline as $\%$ of total convertible currency external debt & 12.9 & 11.5 & 16.4 & 21.1 & 19.8 & 25.6 \\
\hline as $\%$ of GDP & 11.5 & 9.0 & 11.8 & 14.3 & 12.7 & 17.3 \\
\hline$y-0-y$ rate of change & 14.4 & -16.0 & 50.9 & 55.5 & 62.5 & 48.3 \\
\hline
\end{tabular}

Sources: IMF, Comtrade, BIS, Bondware, Loanware, IIF, BNB. 


\begin{tabular}{|c|c|c|c|c|c|c|}
\hline & 2000 & 2001 & 2002 & 2003 & 2004 & $2005^{1}$ \\
\hline \multicolumn{7}{|l|}{ External environment } \\
\hline Exports and imports of goods and services (as a \% of GDP) & 70.7 & 74.5 & 76.5 & 76.9 & 81.0 & 76.5 \\
\hline \multicolumn{7}{|l|}{ Geographical composition of trade } \\
\hline EU-25 (as a \% of total trade) & 67.2 & 69.5 & 67.5 & 70.2 & 68.4 & 64.5 \\
\hline \multicolumn{7}{|l|}{ Exports } \\
\hline Machinery and transport equipment (as a \% of total exports) & 18.8 & 19.9 & 21.3 & 21.8 & 23.9 & 25.6 \\
\hline Chemicals and intermediate goods (as a \% of total exports) & 5.8 & 5.2 & 4.7 & 4.8 & 5.5 & 5.7 \\
\hline Mineral fules, lubricants and related materials (as a $\%$ of total exports) & 7.2 & 6.2 & 7.9 & 6.5 & 6.8 & 10.7 \\
\hline Crude materials, inedible, except fuels (as a \% of total exports) & 9.0 & 6.1 & 5.4 & 6.2 & 6.0 & 4.8 \\
\hline Foodstuffs and agricultural products (as a \% of total exports) & 2.4 & 2.8 & 2.5 & 2.2 & 2.1 & 2.2 \\
\hline Chemicals and intermediate goods (as a \% of total imports) & 10.0 & 9.9 & 10.7 & 10.3 & 10.4 & 10.2 \\
\hline Mineral fules, lubricants and related materials (as a $\%$ of total imports) & 12.1 & 12.7 & 11.1 & 10.9 & 11.8 & 14.0 \\
\hline Crude materials, inedible, except fuels (as a $\%$ of total imports) & 4.3 & 3.3 & 3.1 & 3.0 & 3.0 & 2.8 \\
\hline Foodstuffs and agricultural products (as a $\%$ of total imports) & 5.4 & 6.1 & 4.8 & 5.7 & 4.9 & 4.7 \\
\hline Consumer manufactures (as a $\%$ of total imports) & 10.5 & 10.8 & 11.5 & 11.4 & 9.8 & 9.5 \\
\hline memo: oil and gas (as a $\%$ of total imports) & 10.4 & 10.7 & 9.6 & 9.2 & 9.3 & 11.9 \\
\hline \multicolumn{7}{|l|}{ Financing } \\
\hline Rating History (Moody's foreign currency long term debt, end of year) & B3 & B2 & WR & $\mathrm{Ba} 3$ & $\mathrm{Ba} 3$ & $\mathrm{Bal}$ \\
\hline Bond spreads (basis points, end of year values) & n.a. & 400 & 286 & 161 & 58 & 49 \\
\hline International bonds issuance (in USD million, end of year values) & 260 & 794 & 1,062 & 814 & 0 & 1,199 \\
\hline \multicolumn{7}{|l|}{ Claims by BIS reporting banks } \\
\hline Claims by euro area BIS reporting banks (in USD million) & 3,047 & 3,975 & 5,309 & 8,868 & 15,669 & $\ldots$ \\
\hline Real exports of goods and services & 23.4 & 12.1 & 17.5 & 8.4 & 13.9 & 7.6 \\
\hline Real imports of goods and services & 27.1 & 18.4 & 12.0 & 16.0 & 22.1 & 17.2 \\
\hline Industrial production & 7.1 & 8.3 & 4.3 & 3.1 & 5.3 & 2.0 \\
\hline Number of employees economy-wide (average percentage change) & $\ldots$ & 1.1 & -2.9 & 0.3 & 0.8 & 2.6 \\
\hline Unemployment rate (end of year) & 10.5 & 8.8 & 8.4 & 7.4 & 6.3 & 5.9 \\
\hline Net wages economy-wide (average percentage change) & 49.1 & 40.5 & 27.1 & 25.4 & 22.5 & 23.7 \\
\hline \multicolumn{7}{|l|}{ Prices, exchange rate, interest rate and monetary developments } \\
\hline Consumer price inflation $(\%, y-0-y$, period average $)$ & 45.7 & 34.5 & 22.5 & 15.3 & 11.9 & 9.0 \\
\hline Producer price inflation $(\%, \mathrm{y}-\mathrm{o}-\mathrm{y}$, period average) & 53.4 & 40.3 & 24.5 & 19.6 & 18.6 & 12.4 \\
\hline Exchange rate (domestic currency/EUR, index, period average, $1999=100$ ) & 122.4 & 155.2 & 190.4 & 209.4 & 248.1 & 222.4 \\
\hline Nominal effective exchange rate (index, period average, $1999=100$ ) & 77.1 & 60.0 & 51.7 & 45.4 & 44.6 & ... \\
\hline
\end{tabular}




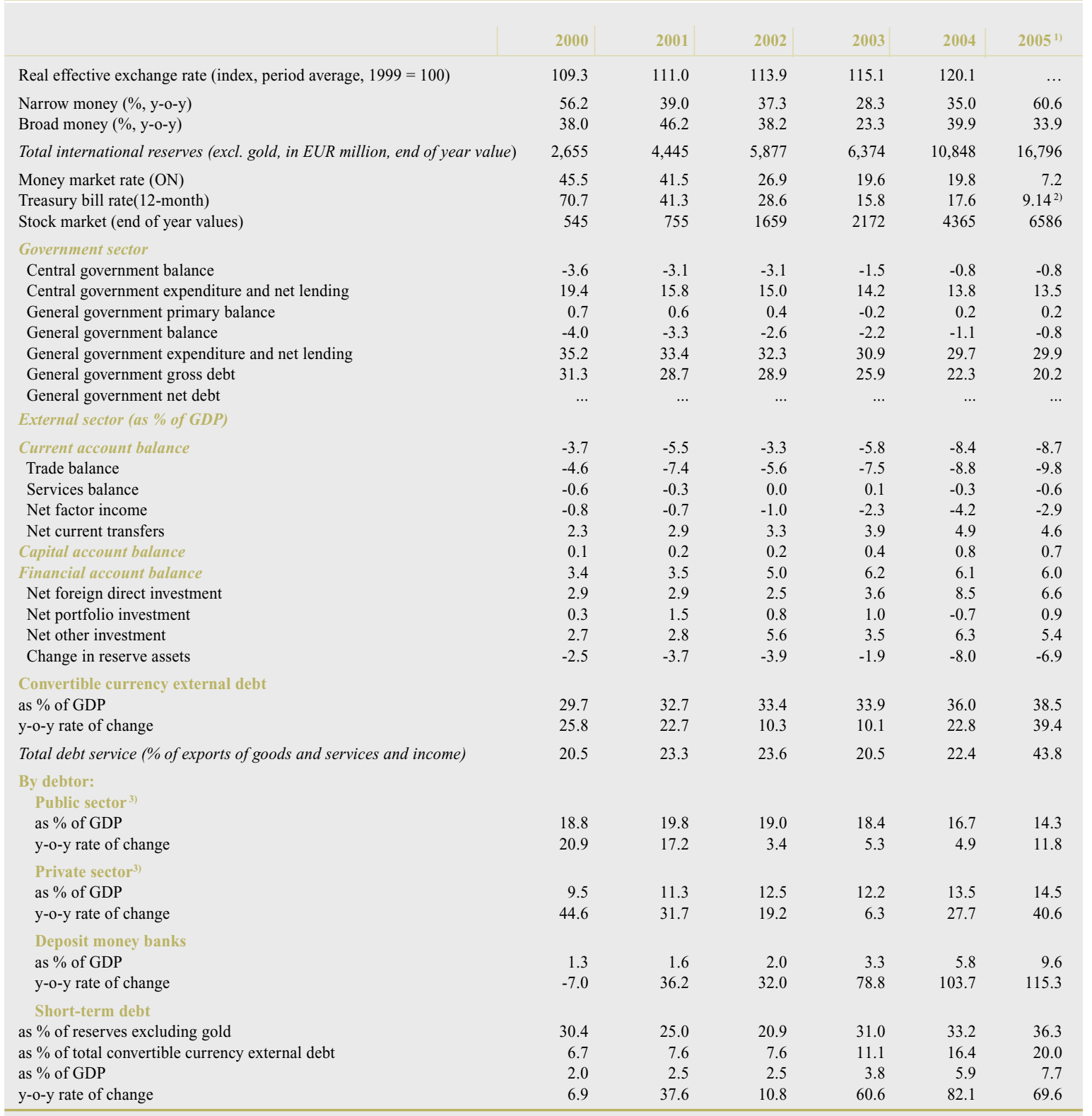

Sources: IMF, Comtrade, BIS, Bondware, Loanware, IIF, NBR.

1) Provisional data.

2) Two-year maturity bonds.

3) Excluding debt owed by deposit money banks. 


\section{Croatia: Selected macroeconomic indicators}

\begin{tabular}{|c|c|c|c|c|c|c|}
\hline & 2000 & 2001 & 2002 & 2003 & 2004 & 2005 \\
\hline \multicolumn{7}{|l|}{ External environment } \\
\hline \multicolumn{7}{|l|}{ Openness } \\
\hline Exports and imports of goods and services (as a \% of GDP) & 99.4 & 103.3 & 102.9 & 110.9 & 110.4 & 108.6 \\
\hline \multicolumn{7}{|l|}{ Geographical composition of trade } \\
\hline EU-25 (as a \% of total trade) & 69.9 & 70.3 & 69.5 & 70.7 & 67.9 & 70.7 \\
\hline Euro area (as a $\%$ of total trade) & 51.2 & 52.4 & 51.4 & 52.4 & 49.5 & 46.3 \\
\hline \multicolumn{7}{|l|}{ Product composition of trade } \\
\hline \multicolumn{7}{|l|}{ Exports } \\
\hline Machinery and transport equipment (as a \% of total exports) & 27.0 & 29.4 & 28.4 & 29.5 & 32.3 & 29.6 \\
\hline Chemicals and intermediate goods (as a \% of total exports) & 12.5 & 10.6 & 10.3 & 9.6 & 9.4 & 9.9 \\
\hline Mineral fules, lubricants and related materials (as a $\%$ of total exports) & 11.0 & 10.2 & 9.3 & 9.6 & 11.3 & 13.6 \\
\hline Crude materials, inedible, except fuels (as a \% of total exports) & 5.7 & 5.2 & 5.6 & 5.7 & 5.6 & 5.5 \\
\hline Foodstuffs and agricultural products (as a $\%$ of total exports) & 6.2 & 6.9 & 8.0 & 9.1 & 6.3 & 7.7 \\
\hline Consumer manufactures (as a \% of total exports) & 20.0 & 20.7 & 20.6 & 19.6 & 17.8 & 16.6 \\
\hline memo: Textiles (as a $\%$ of total exports) & 12.6 & 12.3 & 12.1 & 11.4 & 9.3 & 7.7 \\
\hline \multicolumn{7}{|l|}{ Imports } \\
\hline Machinery and transport equipment (as a \% of total imports) & 32.6 & 33.2 & 34.3 & 37.1 & 34.9 & 32.9 \\
\hline Chemicals and intermediate goods (as a \% of total imports) & 12.7 & 11.5 & 11.3 & 11.0 & 11.2 & 11.1 \\
\hline Mineral fules, lubricants and related materials (as a $\%$ of total imports) & 14.5 & 13.0 & 12.2 & 10.9 & 12.0 & 15.1 \\
\hline Crude materials, inedible, except fuels (as a $\%$ of total imports) & 2.4 & 2.4 & 2.4 & 2.3 & 2.1 & 2.0 \\
\hline Foodstuffs and agricultural products (as a $\%$ of total imports) & 7.1 & 7.7 & 7.4 & 7.0 & 7.2 & 7.2 \\
\hline Consumer manufactures (as a $\%$ of total imports) & 12.0 & 11.5 & 11.6 & 11.6 & 11.9 & 11.6 \\
\hline memo: oil and gas (as a $\%$ of total imports) & 12.9 & 11.4 & 10.8 & 9.6 & 10.4 & 13.0 \\
\hline \multicolumn{7}{|l|}{ Financing } \\
\hline Rating History (Moody's foreign currency long term debt, end of year) & Baa3 & $\mathrm{Baa} 3$ & Baa3 & Baa3 & Baa3 & Baa3 \\
\hline Bond spreads (basis points, end of year values) & & 179 & 124 & 114 & 42 & 37 \\
\hline International bonds issuance (in USD million, end of year values) & 482 & 718 & 647 & 541 & 1,098 & 0 \\
\hline Claims by BIS reporting banks & & & $\cdots$ & & & $\cdots$ \\
\hline Claims by euro area BIS reporting banks (in USD million) & 7,307 & 8,781 & 17,235 & 23,762 & 28,166 & $\ldots$ \\
\hline \multicolumn{7}{|l|}{ Domestic macroeconomic developments } \\
\hline \multicolumn{7}{|l|}{ Real activity ${ }^{1)}$} \\
\hline Real GDP & 2.9 & 4.4 & 5.2 & 4.3 & 3.8 & 4.1 \\
\hline Real domestic demand & -0.3 & 5.5 & 8.8 & 5.2 & 2.9 & 3.7 \\
\hline Real private consumption & 4.2 & 4.5 & 7.5 & 4.1 & 3.9 & 3.5 \\
\hline Real public consumption & -1.5 & -6.2 & -1.8 & -0.3 & -0.3 & 0.7 \\
\hline Real gross fixed capital formation & -3.8 & 7.1 & 12.0 & 16.8 & 4.4 & 3.4 \\
\hline Real exports of goods and services & 12.0 & 8.1 & 1.3 & 10.1 & 5.4 & 4.8 \\
\hline Real imports of goods and services & 3.7 & 9.8 & 8.8 & 10.9 & 3.5 & 3.8 \\
\hline Change in inventories & 413.8 & -180.7 & 194.0 & -18.0 & -6.2 & 30.9 \\
\hline Industrial production ${ }^{2)}$ & 1.7 & 6.0 & 5.5 & 4.0 & 3.6 & 5.1 \\
\hline Employment $^{3)}$ & -1.7 & 0.5 & 0.8 & 2.5 & 1.2 & -0.3 \\
\hline Unemployment $t^{4}$ & 16.1 & 15.8 & 14.8 & 14.3 & 13.8 & 13.1 \\
\hline Wages & 9.1 & 6.9 & 4.6 & 6.1 & 5.8 & 5.1 \\
\hline \multicolumn{7}{|l|}{ Prices, exchange rate, interest rate and monetary developments } \\
\hline Consumer price inflation (\%, y-o-y, period average) & 4.6 & 3.8 & 1.7 & 1.8 & 2.1 & 3.3 \\
\hline Producer price inflation $(\%, y-0-y$, period average $)$ & 9.7 & 3.6 & -0.4 & 1.9 & 3.5 & 3.0 \\
\hline Exchange rate (domestic currency/EUR, index, period average, $1999=100$ ) & 100.7 & 98.5 & 97.7 & 99.8 & 98.9 & 97.6 \\
\hline Nominal effective exchange rate (index, period average, $1999=100$ ) & 104.8 & 103.4 & 101.2 & 98.2 & 94.8 & 93.5 \\
\hline
\end{tabular}

Sources: $\mathrm{CNB}, \mathrm{MoF}$ and $\mathrm{CBS}$.

1) According to official CBS data for the first three quarters and latest official CNB projection for the last quarter of 2005

2) Non-seasonally adjusted data.

3) Preliminary data for 2005 .

4) The 2005 data are for the first half of the year. 
Real effective exchange rate (index, period average,

PPI deflated, $1999=100)$
Real effective exchange rate (index, period average,

CPI deflated, $1999=100$ )

Narrow money (\%, y-o-y)

Broad money (\%, y-o-y)

Total international reserves (excl. gold, in USD million, end of year value) $\quad 3,525$

Money market rate

Treasury bill rate

Stock market (end of year values)

Government sector

Central government balance ${ }^{5}$

Central government expenditure and net lending

General government primary balance

General government balance ${ }^{6}$

General government expenditure and net lending

General government gross debt?

General government net debt

External sector

Current account balances

Trade balance

Services balance

Net factor income

Net current transfers

Capital account balance ${ }^{8)}$

Financial account balance ${ }^{8}$

Net foreign direct investment

Net portfolio investment

Net other investment

Change in reserve assets

External debt

as $\%$ of GDP")

y-o-y rate of change

Total debt service (\% of exports of goods and services and income)

2000

2001

2002

2003

2004

2005

101.5

98.7

96.3

94.2

90.7

91.1

$\begin{array}{rrrrrr}102.9 & 100.4 & 98.6 & 96.1 & 93.0 & 91.0\end{array}$

30.1

31.5

45.7

30.2

9.8

10.7

2.0

91.0
12.3

4,704

5,886

8,191

8.2
8,759

10.7

6.8

n.a.

3.4

5,886
1.7

n.a.

2.6

3.3

8,801

n.a.

1,173

5.1
5.7

1,565

4.2

1,998

$-7.1$

-7.1
48.8

$-5.4$

46.8

$-5.0$

$\begin{array}{lll}-4.9 & -4.5 & -3.8\end{array}$

$\begin{array}{lll}45.1 & 45.4 & 43.4\end{array}$

$\begin{array}{lll}-3.1 & -3.0 & -1.5\end{array}$

$\begin{array}{lll}-3.1 & -3.0 & -1.5 \\ -6.3 & -4.9 & -4.2 \\ 49.5 & 49.8 & 48.3\end{array}$

$\begin{array}{lll}49.5 & 49.8 & 48.3\end{array}$

$\begin{array}{lll}42.0 & 44.9 & 45.5\end{array}$

$50.8 \quad 48.8$

$40.6-40.4$

39.7

39.7
$\quad \ldots$

...

$-3.7$

$-20.8$

14.9

$-2.8$

5.0

0.7

4.0

6.0

3.0

2.0

$-7.0$

$-8.4$

$-24.6$

13.6

$-2.4$

4.8

2.1

9.2

2.5

$-1.8$

11.6

$-3.1$

$-7.3$

$-27.3$

19.3

$-4.2$

4.9

0.3

11.5

6.6

3.4

6.2

$-4.8$

...

$\begin{array}{ll}-5.2 & -5.9 \\ -2.4 & -24.6\end{array}$

$-24.4 \quad-24.6$

$17.1 \quad 17.8$

$-2.3 \quad-3.2$

$4.3 \quad 4.0$

$0.1 \quad 0.0$

$8.4 \quad 9.8$
2.6

$2.6 \quad 6.2$

$\begin{array}{ll}0.9 & -1.7\end{array}$

5.1

$-0.2$

60.7

62.2

77.6

82.5

$-0$.

60.6

19.9

11.1

11.9

31.6

19.4

15.0

15.0
19.7

84.7

12.0

By debtor:

Public secto ${ }^{10)}$

as \% of GDP ${ }^{9}$

$y-0-y$ rate of change

Private sector:

as $\%$ of GD ${ }^{9}$

$\mathrm{y}-\mathrm{o}-\mathrm{y}$ rate of change

Deposit money banks

as $\%$ of GDP ${ }^{9}$

$\mathrm{y}-\mathrm{o}-\mathrm{y}$ rate of change

Short-term debt

as $\%$ of reserves excluding gold

as $\%$ of total external debt

as $\%$ of GDP ${ }^{9}$ )

y-o-y rate of change

$\begin{array}{rrrrrr}34.8 & 33.8 & 29.8 & 32.6 & 31.0 & 27.9 \\ 26.7 & 7.7 & -3.6 & 15.5 & 2.7 & -1.8 \\ 25.8 & 26.9 & 32.4 & 45.0 & 51.5 & 56.8 \\ 15.6 & 15.8 & 31.3 & 46.4 & 23.9 & 20.2 \\ & & & & & \\ 11.0 & 11.5 & 15.6 & 24.0 & 27.9 & 29.8 \\ 2.8 & 16.0 & 48.8 & 61.5 & 25.8 & 16.7 \\ & & & & & \\ 25.5 & 10.8 & 10.1 & 24.8 & 40.7 & 48.5 \\ 8.0 & 4.3 & 3.8 & 8.2 & 11.5 & 14.2 \\ 4.8 & 2.6 & 2.4 & 6.4 & 9.5 & 12.0 \\ 49.2 & -40.1 & -1.2 & 185.4 & 60.8 & 37.9\end{array}$

5) On a cash basis.

6) On a modified accrual basis.

7) Includes debt of the Republic of Croatia, central government funds debt and local government debt.

8) According to preliminary CNB data for the first three quarters and latest official CNB projection for the last quarter of 2005.

9) For 2005 GDP is calculated as the sum of GDP realizations in the first, second and third quarter of 2005 and the latest official CNB projection for the last quarter of 2005 . 
Turkey: Selected macroeconomic indicators

\begin{tabular}{|r|r|r|r|r|}
\hline 2000 & 2001 & 2003 & 2004 & 2005 \\
\hline
\end{tabular}

External environment

Openness

Exports and imports of goods and services (as a $\%$ of GDP)

56.9

Geosition of trade

EU-25 (as a \% of total trade)

Euro area (as a $\%$ of total trade)

Product composition of trade

Exports

Machinery and transport equipment

(as a $\%$ of total exports)

Chemicals and intermediate goods

(as a \% of total exports)

Mineral fules, lubricants and related materials

(as a \% of total exports)

Crude materials, inedible, except fuels

(as a $\%$ of total exports)

Foodstuffs and agricultural product

(as a $\%$ of total exports)

Consumer manufactures

(as a $\%$ of total exports)

memo: Textiles

(as a \% of total exports)

Import:

Machinery and transport equipment

(as a \% of total imports)

Chemicals and intermediate goods

(as a \% of total imports)

Mineral fules, lubricants and related materials

(as a $\%$ of total imports)

Crude materials, inedible, except fuels

(as a $\%$ of total imports)

Foodstuffs and agricultural products

(as a \% of total imports)

Consumer manufactures

memo: oil and gas

(as a \% of total imports)

Financing

Rating History (Moody's foreign currency

long term debt, end of year)

Bond spreads (basis points, end of year values)

International bonds issuance (in USD million,

end of year values)

Claims by BIS reporting banks

Claims by euro area BIS reporting banks

(in USD million)

Domestic macroeconomic developments

Real activity

Real GDP

Real domestic demand

Real private consumption

Real public consumption

Real gross fixed capital formation

Real exports of goods and services

Real imports of goods and services

Change in inventories

Industrial production

Employment

Unemployment

Wages

51.

41.7

4.5

1.1

28.5

28.5

14.1

B1
803

24,993 (as a \% of total imports)

$$
40.0
$$

20.8

4.5

2.8

10.4

37.2

39.1

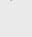

14.4

6.3

2.2

6.3

B1

7,330

20,366

20,313

22,530

B1
309

5,454

264

6,477

26,207

Sources: IMF, Comtrade, BIS, Bondware, Loanware, IIF

$\begin{array}{rrrrrr}7.4 & -7.5 & 7.9 & 5.8 & 8.9 & 5.0 \\ 10.0 & -18.6 & 9.4 & 9.4 & 14.1 & 4.2 \\ 6.3 & -9.3 & 2.2 & 6.7 & 9.9 & 4.5 \\ 7.1 & -8.5 & 5.4 & -2.4 & 0.5 & 2.0 \\ 17.3 & -31.5 & -1.1 & 10.0 & 32.4 & 7.8 \\ 19.2 & 7.4 & 11.1 & 16.0 & 12.5 & 8.7 \\ 25.4 & -24.8 & 15.8 & 27.1 & 24.7 & 6.8 \\ 2.2 & -1.4 & 4.7 & 7.3 & 7.9 & 6.8 \\ 6.1 & -8.7 & 9.5 & 8.7 & 9.9 & \ldots \\ -0.1 & -2.3 & -0.8 & -0.3 & 2.0 & \ldots \\ 6.6 & 8.5 & 10.3 & 10.5 & 10.0 & 9.8 \\ & & & & & \end{array}$


Prices, exchange rate, interest rate and

monetary developments

Consumer price inflation ( $\%, y-0-y$, period average)

Producer price inflation ( $\%, \mathrm{y}-\mathrm{o}-\mathrm{y}$, period average)

Exchange rate (domestic currency/EUR,

index, period average, $1999=100$ )

Nominal effective exchange rate

(index, period average, $1999=100$ )

Real effective exchange rate

(index, period average, $1999=100$ )

Narrow money (\%, y-o-y)

Broad money (\%, y-o-y)

Total international reserves

(excl. gold, in USD million, end of year value)

Money market rate

Treasury bill rate

Stock market

Government sector

Central government balance

Central government expenditure and net lending

General government primary balance

General government balance

General government expenditure and net lending

General government gross debt

General government net debt

External sector

Current account balance

Trade balance

Services balance

Net factor income

Net current transfers

Capital account balance

Financial account balance

Net foreign direct investment

Net portfolio investment

Net other investment

Change in reserve assets

Convertible currency external debt

as $\%$ of GDP

$\mathrm{y}$-o-y rate of change

Total debt service

(\% of exports of goods and services and income)

By debtor:

Public sector*

as $\%$ of GDP

$\mathrm{y}-0$-y rate of change

Private sector:

as $\%$ of GDP

$y-0-y$ rate of change

Deposit money banks

as \% of GDP

$y-0-y$ rate of change

Short-term debt

as $\%$ of reserves excluding gold

as $\%$ of total convertible currency external debt

as \% of GDP

$\mathrm{y}$-o-y rate of change

\section{0}

2001

2002

2003

2004

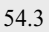

53.9

129.1

245.8

44.8

25.2

10.3

$\begin{array}{rr}54.3 & 53.9 \\ \cdots & \ldots\end{array}$

317.9

379.7

396.7

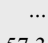

57.3
40.5

46.3

$40.5 \quad 86.2$

36.7

22,488

56.7

56.7
25.2

9,437

18,879

92.0

85.3

13,783

27,069
49.5

59.5
10,370

36.2

36.2
34.9

18,625

39,778

-11.2
37.5

$-17.4$

$-14.9$

41.7

$-11.0$

39.0

1.6

$-14.4$

4.9
-21.4

$-2.5$

-18.6
45.9

92.8

106.8

99.1

85.6

82.7

82.7
77.2

18.0

16.9 


\section{REFERENCES}

Barisitz S. (2004), "The Transformation of the Romanian Financial and Banking Sector", OeNB Financial Stability Report 7, 88-100.

Claessens, S. and L. Laeven (2004), "What Drives Bank Competition? Some International Evidence", Journal of Money, Credit and Banking, 36, 563-584.

Clarke, George; Cull, Robert; Martinez Peria, Maria Soledad; Sanchez, Susana M. (2001), "Does foreign bank penetration reduce access to credit in developing countries?", WB Policy Research Working Paper 2716, Washington, D.C.

Clarke, George; Cull, Robert; Martinez Peria, Maria Soledad; Sanchez, Susana M. "Foreign bank entry", WB Policy Research Working Paper 2698, Washington, D.C.

De Haas, R. and I. I. P van Lelyveld (2002), "Foreign bank penetration and private sector credit in Central and Eastern Europe", DNB Staff Report 91.

Duenwald C., Gueorguiev N., Schaechter A. (2005), "Too Much of a Good Thing? Credit Booms in Transition Economies: The Cases of Bulgaria, Romania, and Ukraine", IMF Working Paper 05/128, Washington, D.C.

Hilbers, P., I. Otker-Robe, C. Pazarbasioglu and G. Johnsen (2005), "Assessing and Managing Rapid Credit Growth and the Role of Supervisory and Prudential Policies", IMF Working Paper No. 05/151, Washington, D.C.

IMF (2003), Romania: Financial System Stability Assessment, Including Reports on the Observance of Standards and Codes on the following topics: Banking Supervision, Securities Regulation, Anti-Money Laundering and Combating the Financing of Terrorism, Monetary and Financial Policy Transparency, IMF Country Report No. 03/389, Washington, D.C.

Kaminsky, G. L. and C. M. Reinhart (2000), "On crisis, contagion and confusion", Journal of International Economics, 51 (1), 145-168.

Peek, J. and E. Rosengren (2000), "Collateral Damage: Effects of the Japanese Bank Crisis on Real Activity in the United States", American Economic Review, 90 (1), 30-45.

Reininger, T., Walko, Z. (2005), "The Croatian Banking System”, Financial Stability Report No. 9, Oesterreichische Nationalbank, Vienna.

Sbracia, M. and A. Zaghini (2001), "The Role of the Banking System in the International Transmission of Shocks", Banca D'Italia Discussion Paper No. 409.

Van Rijckeghem, C. and B. Weder (2001), "Sources of Contagion: Is it Finance or Trade?", Journal of International Economics, 54 (2), 293-308.

Walko, Z. (2004), "The Bulgarian Financial Sector", Financial Stability Report No. 8, Oesterreichische Nationalbank, Vienna. 
Weill, L. (2003), "Banking efficiency in transition economies", Economics of Transition, 11 (3), 569-592. 


\section{EUROPEAN CENTRAL BANK}

\section{OCCASIONAL PAPER SERIES}

1 "The impact of the euro on money and bond markets" by J. Santillán, M. Bayle and C. Thygesen, July 2000.

2 "The effective exchange rates of the euro" by L. Buldorini, S. Makrydakis and C. Thimann, February 2002.

3 "Estimating the trend of M3 income velocity underlying the reference value for monetary growth" by C. Brand, D. Gerdesmeier and B. Roffia, May 2002.

4 "Labour force developments in the euro area since the 1980s" by V. Genre and R. Gómez-Salvador, July 2002.

5 "The evolution of clearing and central counterparty services for exchange-traded derivatives in the United States and Europe: a comparison" by D. Russo, T. L. Hart and A. Schönenberger, September 2002.

6 "Banking integration in the euro area" by I. Cabral, F. Dierick and J. Vesala, December 2002.

7 "Economic relations with regions neighbouring the euro area in the "Euro Time Zone" by F. Mazzaferro, A. Mehl, M. Sturm, C. Thimann and A. Winkler, December 2002.

8 "An introduction to the ECB's survey of professional forecasters" by J. A. Garcia, September 2003.

9 "Fiscal adjustment in 1991-2002: stylised facts and policy implications" by M. G. Briotti, February 2004.

10 "The acceding countries' strategies towards ERM II and the adoption of the euro: an analytical review" by a staff team led by P. Backé and C. Thimann and including O. Arratibel, O. CalvoGonzalez, A. Mehl and C. Nerlich, February 2004.

11 "Official dollarisation/euroisation: motives, features and policy implications of current cases" by A. Winkler, F. Mazzaferro, C. Nerlich and C. Thimann, February 2004.

12 "Understanding the impact of the external dimension on the euro area: trade, capital flows and other international macroeconomic linkages" by R. Anderton, F. di Mauro and F. Moneta, March 2004.

13 "Fair value accounting and financial stability" by a staff team led by A. Enria and including L. Cappiello, F. Dierick, S. Grittini, A. Maddaloni, P. Molitor, F. Pires and P. Poloni, April 2004.

14 "Measuring financial integration in the euro area" by L. Baele, A. Ferrando, P. Hördahl, E. Krylova, C. Monnet, April 2004. 
15 "Quality adjustment of European price statistics and the role for hedonics" by H. Ahnert and G. Kenny, May 2004.

16 "Market dynamics associated with credit ratings: a literature review" by F. Gonzalez, F. Haas, R. Johannes, M. Persson, L. Toledo, R. Violi, M. Wieland and C. Zins, June 2004.

17 “Corporate 'excesses' and financial market dynamics" by A. Maddaloni and D. Pain, July 2004.

18 "The international role of the euro: evidence from bonds issued by non-euro area residents" by A. Geis, A. Mehl and S. Wredenborg, July 2004.

19 "Sectoral specialisation in the EU: a macroeconomic perspective" by MPC task force of the ESCB, July 2004.

20 "The supervision of mixed financial services groups in Europe" by F. Dierick, August 2004.

21 "Governance of securities clearing and settlement systems" by D. Russo, T. Hart, M. C. Malaguti and C. Papathanassiou, October 2004.

22 "Assessing potential output growth in the euro area: a growth accounting perspective" by A. Musso and T. Westermann, January 2005.

23 "The bank lending survey for the euro area" by J. Berg, A. van Rixtel, A. Ferrando, G. de Bondt and S. Scopel, February 2005.

24 "Wage diversity in the euro area: an overview of labour cost differentials across industries" by V. Genre, D. Momferatou and G. Mourre, February 2005.

25 "Government debt management in the euro area: recent theoretical developments and changes in practices" by G. Wolswijk and J. de Haan, March 2005.

26 "The analysis of banking sector health using macro-prudential indicators" by L. Mörttinen, P. Poloni, P. Sandars and J. Vesala, March 2005.

27 "The EU budget - how much scope for institutional reform?" by H. Enderlein, J. Lindner, O. Calvo-Gonzalez, R. Ritter, April 2005.

28 "Reforms in selected EU network industries" by R. Martin, M. Roma, I. Vansteenkiste, April 2005.

29 "Wealth and asset price effects on economic activity", by F. Altissimo, E. Georgiou, T. Sastre, M. T. Valderrama, G. Sterne, M. Stocker, M. Weth, K. Whelan, A. Willman, June 2005.

30 "Competitiveness and the export performance of the euro area", by a Task Force of the Monetary Policy Committee of the European System of Central Banks, June 2005.

31 "Regional monetary integration in the member states of the Gulf Cooperation Council (GCC)" by M. Sturm and N. Siegfried, June 2005. 
32 "Managing financial crises in emerging market economies: experience with the involvement of private sector creditors" by an International Relations Committee task force, July 2005.

33 "Integration of securities market infrastructures in the euro area" by H. Schmiedel, A. Schönenberger, July 2005.

34 "Hedge funds and their implications for financial stability" by T. Garbaravicius and F. Dierick, August 2005.

35 "The institutional framework for financial market policy in the USA seen from an EU perspective" by R. Petschnigg, September 2005.

36 "Economic and monetary integration of the new Member States: helping to chart the route" by J. Angeloni, M. Flad and F. P. Mongelli, September 2005.

37 "Financing conditions in the euro area" by L. Bê Duc, G. de Bondt, A. Calza, D. Marqués Ibáñez, A. van Rixtel and S. Scopel, September 2005.

38 "Economic reactions to public finance consolidation: a survey of the literature" by M. G. Briotti, October 2005.

39 "Labour productivity in the Nordic EU countries: a comparative overview and explanatory factors - 1998-2004" by A. Annenkov and C. Madaschi, October 2005.

40 "What does European institutional integration tell us about trade integration?" by F. P. Mongelli, E. Dorrucci and I. Agur, December 2005.

41 "Trends and patterns in working time across euro area countries 1970-2004: causes and consequences" by N. Leiner-Killinger, C. Madaschi and M. Ward-Warmedinger, December 2005 .

42 "The New Basel Capital Framework and its implementation in the European Union" by F. Dierick, F. Pires, M. Scheicher and K. G. Spitzer, December 2005.

43 "The accumulation of foreign reserves" by an International Relations Committee Task Force, February 2006.

44 "Competition, productivity and prices in the euro area services sector" by a Task Force of the Monetary Policy Committee of the European System of Central banks, April 2006.

45 "Output growth differentials across the euro area countries: Some stylised facts" by N. Benalal, J. L. Diaz del Hoyo, B. Pierluigi and N. Vidalis, May 2006.

46 "Inflation persistence and price-setting behaviour in the euro area - a summary of the IPN evidence", by F. Altissimo, M. Ehrmann and F. Smets, June 2006.

47 "The reform and implementation of the stability and growth pact" by R. Morris, H. Ongena and L. Schuknecht, June 2006. 
48 "Macroeconomic and financial stability challenges for acceding and candidate countries" by the International Relations Committee Task Force on Enlargement, July 2006.
EUROPEAN CENTRAL BANK OCCASSIONAL PAPER SERIES 
ISSN 1607148-4 